$2^{2}$

Idaho

National

Engineering

Laboratory

Managed

by the U.S.

Department

of Energy
APR 271992

INFORMAL REPORT

EGG-NE-9768
MSO01.3

(a)

CRITICALITY SAFETY EVALUATION OF ROCKY FLATS PLANT ONE-GALLON SHIPPING CONTAINERS

Maria E. Shaw

Published December 1991

INCL

EG\&G Idaho, Inc.

Idaho Falls, ID 83415

$\sum_{0}^{\pi} E E_{2 \pi} G_{\text {iata no }}$

Work performed under

DOE Contract

No. DE-ACO7-761D01570

DISTRIBUTION OF THIS DOCUMENT IS UNLIMITED 


\section{CRITICALITY SAFETY EVALUATION OF ROCKY FLATS \\ PLANT ONE-GALLON SHIPPING CONTAINERS}

Maria E. Shaw

Published December 1991

INEL

EG\&G Idaho, Inc.

Idaho Falls, ID 83415

$\frac{\text { d. Blain Bugze }}{\text { Checked by }}$

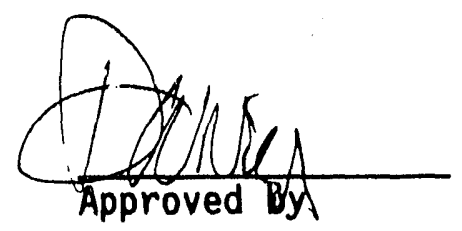

Prepared for the

U.S. Department of Energy Idaho Operations office

Under DOE Contract No. DE-AC07-76ID01570 
CONTENTS

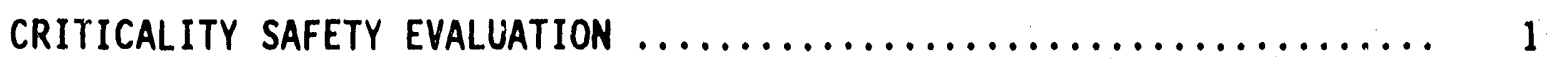

CRITICALITY SAFETY EVALUATION SIGN-OFF SHEET $\ldots \ldots \ldots \ldots \ldots \ldots \ldots, 2$

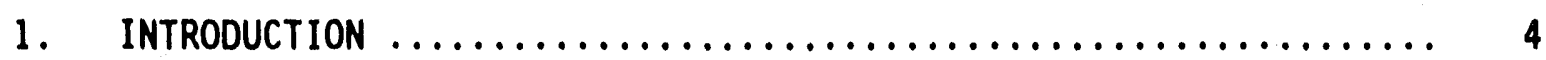

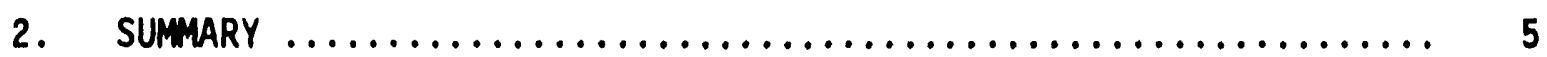

3. APPROVED EQUIPMENT LIST $\ldots \ldots \ldots \ldots \ldots \ldots \ldots \ldots \ldots \ldots \ldots \ldots \ldots$

4. EVALUATION ASSUMPTIONS $\ldots \ldots \ldots \ldots \ldots \ldots \ldots \ldots \ldots \ldots \ldots \ldots \ldots$

5. REQUIRED CONTROLS AND ENGINEERED SAFETY FEATURES $\ldots \ldots \ldots \ldots \ldots 10$

5.1 Required Controls ............................ 10

5.2 Engineered Safety Features $\ldots \ldots \ldots \ldots \ldots \ldots \ldots \ldots \ldots, 10$

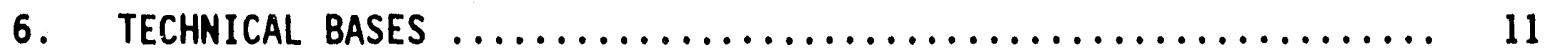

6.1 Technical Bases for Controls ...................... 11

5.2 Technical Bases for Engineered Safety Features ......... 12

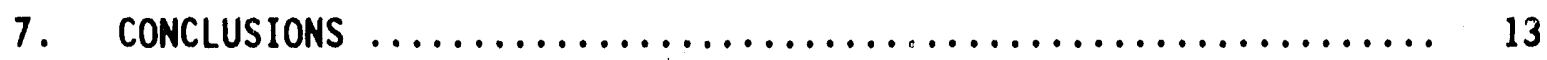

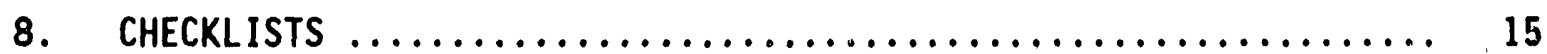

8.1 Double Contingency Analys is $\ldots \ldots \ldots \ldots \ldots \ldots \ldots \ldots \ldots .15$

8.2 Normal Condition Analysis for Shipping Container Operations ..................................... 16

8.3 Failure Analysis Checklist for Shipping Container

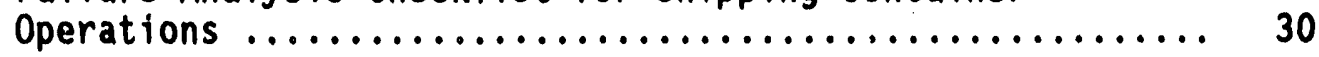

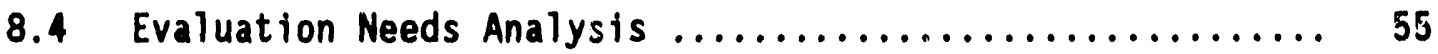

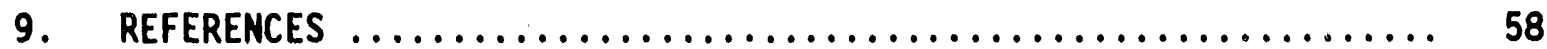

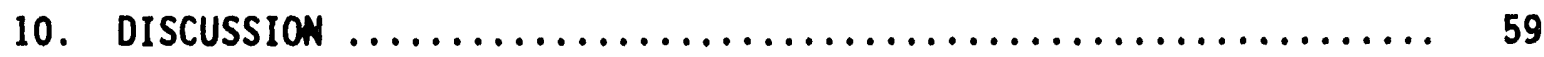

10.1 Codes, Cross Sections and Validations ............... 59

10.2 Dry Uranium and Plutonium Metal $\ldots \ldots \ldots \ldots \ldots \ldots \ldots .60$

10.3 Plutonium Solution ............................. 64

10.4 Metal Slurries ............................... 67 
CONTENTS, cont'd

11. SCALED DRAWING OF THE CONDITIONS MODELED $\ldots \ldots \ldots \ldots \ldots \ldots \ldots \ldots$

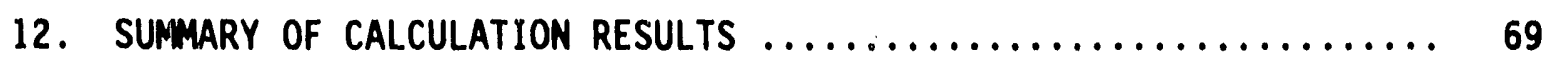

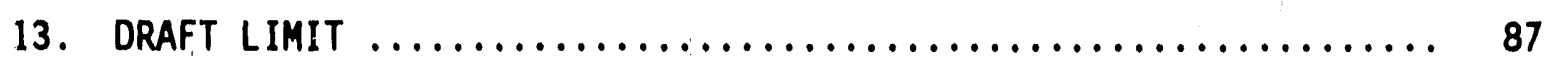

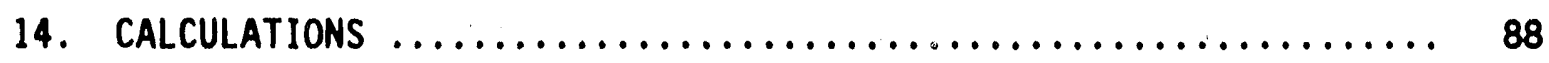

14.1 Calculated Number Densities for Material ............ 88

14.2 Calculation of Average $k_{\text {eff }} \ldots \ldots \ldots \ldots \ldots \ldots \ldots \ldots \ldots$

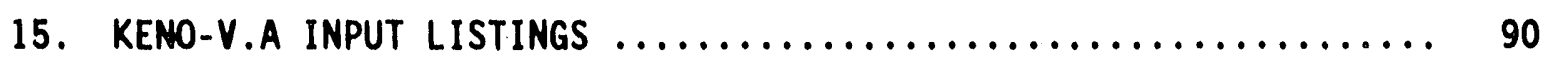


EGG-NE-9768

MSO01.3

FIGURES

1. Unit cell use for representing arrays of cans with offset

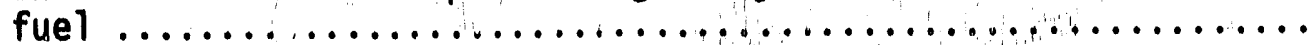

2. Effects of all degrees of moderation, Pu metal cases ........ 71

3. Volume of $\mathrm{Pu}$ solution vs. " $k$, double-batched one-gallon cans, stacked 3 high (offset, spherical fuel) ............. 77

4. Effects of stacking arrays of cans with $1 / 2$ inch lead

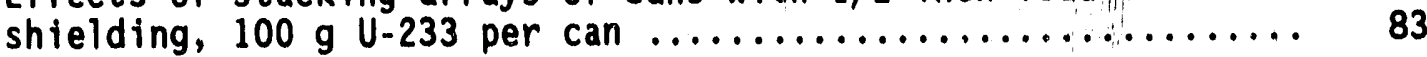

5. Density vs. k-effective; $200 \mathrm{~g}$ Pu per can, cans stacked 3 high 86

TABLES

1. Summary of Results For Pu Solution (1000 Grams/Liter) ....... 13

2. Summary of KENO-V.a Results For Pu Metal Showing the Effects

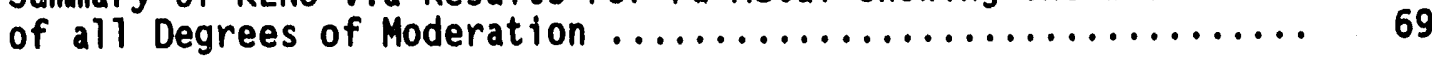

3. Summary of KENO-V.a Results for Pu Metal ............... 72

4. Summary of KENO-V.a Results for Pu Solution Showing the Effects of Variation in the Volume of Fuel .............. 73

5. Summary of KENO-V.a Results for Pu Solution Showing the Effects of All Degrees of Moderation .................. 74

6. Summary of KENO-V.a Results for Plutonium Solution .......... 76

7. Summiary of KENO-V.a Results Showing the Effects of Interaction with Slab of Plutonium Solution Having a $k_{\text {off }}$ of 0.90 (Reference 1, Section 5.2.4) ....................... 78

8. Summary of KENO-V.a Results for Alternate Geometries ......... 79

9. Summary of KENO-V.a Results for U-233 Metal Shoming the

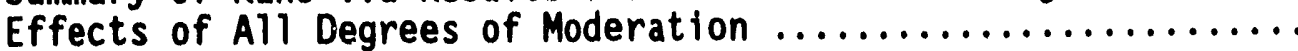

10. Summary of KENO-V.a Results for U-233 Metal Showing the Effect of Stacking Cans with $1 / 2$ Inch Lead Shielding

11. Summary of KENO-V.a Results for Pu Metal Showirig the Effect of Increasing Density 
NMSL: $\quad 90240$

Engineer: MSOO1.3

Date: December 1991

Page: 1 of 116

CRITICALITY SAFETY EVALUATION

OPERATION TITLE: Handling, Shioping and Storage of RFP one-gallon containers BUILDING: All

AREA: Intraolant

DATE OF EVALUATION: December 1991

eVAluator: Mavie \& Shaw

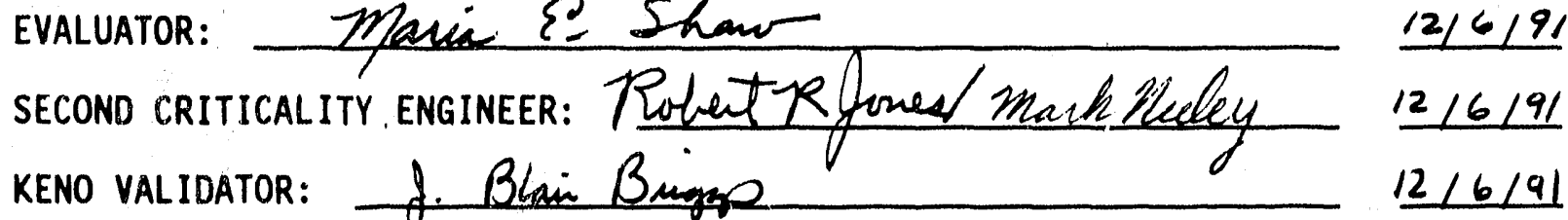

f. Blain Bmgap

$12 / 6 / 91$

TECHNICAL REVIEWER:

MANAGER APPROVAL:

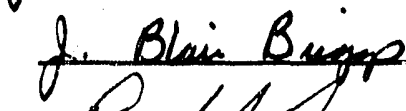

$12 / 6 / 91$

OPERATIONS CONCURRENCE:

OPERATIONS REVIEW COMMITTEE:

Stemerey

$12 / 9191$

$12 / 13 / 9)$

$12 / 18 / 91$

Operations concurrence on this form indicates that they have read and understand the CSOBS and indicates that they acknowledge the required controls and ESFs are controlled under CCCP. 
NMSL: $\quad 90240$

Engineer: MSOO1.3

Date: $\quad$ December 1991

Page: 2 of 116

\section{CRITICALITY SAFETY EVALUATION SIGN-OFF SHEET}

Operation: Handling. Shipoing and Storage of REP one-gallon containers

Date: $\quad$ December 1991

\section{1) DOCUMENTATION REQUIREMENTS}

The Cover Sheet, Sign off Sheet, and the following items have been adequately documented and verified by Reviewer). (Technical

1. Introduction (Request and Operation Description, etc.)

2. Summary

3. Approved Equipment List

4. Evaluation Assumptions

5. Required Controls and Engineered Safety Features

6. Technical Bases

7. Conclusions (e.g., Request acceptable, limit changed, etc.)

8. Checklists (Evaluation Criteria Checksheets, etc.)

9. References (Previous Evaluations etc.)

10. Discussion

11 Scaled Drawings of the Condition(s) Being Evaluated.

12. Summary of Calculation Results (e.g., k kffs, etc.)

13. Draft Limit

14. Calculations

15. KENO Input and Output

\section{2) CONDITIONS TO CALCULATE}

The normal and abnormal condition analysis forms were complete yani s show (Evaluator) with appropriate input from engineering, operations, etc.

The normal and abnormal conditions calculated were reviewed by d. Blai 13 (Technical Reviewer) with appropriate input from engineering, operations, etc.

\section{3) CALCUI_ATIONAL MODEL}

The calculational model was designed by masears Shrw (Evaluator).

The calculational model was reviewed by $d$. Bhai B ing (Technical Reviewer), and it was found to be neithen non conservative, nor too conservative. 
NMSL: $\quad 90240$

Engineer: MSOOL.3

Date: December 1991

Page: 3 of 116

\section{4) PREPARE INPUT DATA}

The computer input data was prepared by Masie SShaw (Evaluator). The computer input data was reviewed by Rohet $R$ fone (2na Engineer), and found to be correct with respect to what was said to be modeled and with the proper selection of computer program options.

\section{5) COMPUTER USE}

The use of the computer program, and cross sections for this evaluation have been approved by

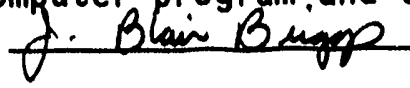
(KENO Vaildator).

\section{6) INTERPRET RESULTS}

The results have been reviewed and checked by Mepeefly.

(2nd Engineer), who has determined that the answers were not misread, the calculation converged, there was representative sampling for Monte Carlo calculations.

\section{7) COMUNICATE CONCLUSIONS}

The assumptions, result bias, and conclusions of the calculation study are documented in the evaluation and have been check for logic and no conclusion is based on only one calculation by $f$. Bhas Buserical Reviewer).

\section{8) REVIEW}

Calculational studies that are not considered routine or that support a change in plant philosophy are to be reviewed by an independent review team as specified by the Criticality Engineering Manager.

Additional Peer Review Required Yes

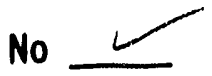
If yes, Level I or Level II

(CE Manager)

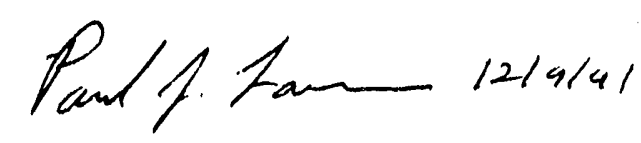


NMSL: $\quad 90240$

Engineer: MSOO1.3

Date: December 1991

Page: 4 of 116

\section{INTRODUCTION}

An initial criticality safety evaluation of Rocky Flats Plant (RFP) One-Gallon Shipping Containers is reported in Reference 1. Due to operational requirements, it is desirable to remove or modify some of the limits and restrictions imposed by the previous evaluation. Specifically, the following changes have been requested:

1. Remove the container limit (20 containers in one location).

2. Apply a mass limit for "dry" plutonium and uranium metal and increase that limit from 20 grams to 50 grams per container. Extend the range of applicability to include plutonium and uranium slurries.

3. Establish a volume limit for plutonium solutions based on a concentration of 1000 grams/liter.

4. Remove the administrative spacing requirement.

This evaluation is being performed to supplement the Reference 1 evaluation and to comply with current requirements. This report documents additional calculations and results that were performed in support of the above modifications. 


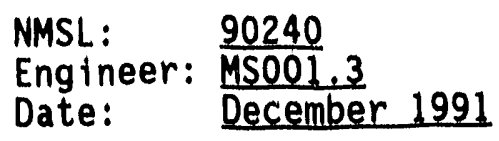

Page: 5 of 116

\section{SUMMARY}

Criticality safety calculations have been performed to provide an analytical basis for handling, storage and transport of RFP one-gallon shipping containers. A mass limit was established for metal (solid uranium or plutonium) and slurries (undissolved $U$ or Pu solids in a "mud", "sludge", or "slurry"). A separate volume limit was developed for plutonium solutions (1iquids, either aqueous or organic, containing no visible undissolved solids).

This analysis has been categorized as Quality Level A (according to EG\&G Idaho Quality Manual) and is intended to comply with NQA-1.

For convenience, normal case conditions for RFP one-gallon shipping containers were modeled as infinite arrays of containers. Arrays were reflected tightly on top by $30 \mathrm{~cm}$ of concrete and on the bottom by $60 \mathrm{~cm}$ of concrete. These normal (non-accident) cases were analyzed with mass or volume values at the limits (50 g "dry" plutonium or uranium metal, or $100 \mathrm{ml}$ plutonium solution per container). $K_{\text {off }}$ values of $0.534 \pm 0.002$ and $0.572 \pm$ 0.004 were calculated for $\mathrm{Pu}$ and $U-233$ metals, respectively. The normal values for $P u$ and $U-233$ slurries were $0.629 \pm 0.003$ and $0.458 \pm 0.003$. Metal and slurry cases for this limiting normal condition were stacked 20 high (as discussed in the accident section below and in Section 10.2). The limiting normal case for solution (only Pu solutions were evaluated) was represented as a $p l$ anar array and produced a $k_{\text {eff }}$ of $0.392 \pm 0.002$.

To more closely represent typical operating conditions, infinite planar arrays of cans containing the various materials were evaluated with no stacking. Solution concentrations were reduced 10 grams/liter. The resulting $k_{\text {eff }}$ for $P u$ solution was $0.051 \pm 0.001$. Calculated $k_{\text {eff }}$ values of $0.203 \pm$ 0.002 and $0.219 \pm 0.002$ resulted for typical condition dry plutonium and $\mathrm{U}-233$ metal systems, respectively. Slurries were slightly less reactive at $0.168 \pm$ $0.002(\mathrm{Pu})$ and $0.095 \pm 0.001(\mathrm{U}-233)$. 
NMSL: $\quad 90240$

Engineer: $\mathrm{MSOO1}, 3$

Date: December 1991

Page: 6 of 116

The following accidents were evaluated:

1. Accidents for "dry" $\mathrm{Pu}$ or $U$ metal and metal slurries
a. Mass violation (double-batching)
b. Flooding
c. Sprinkler accident
d. Vehicle accident, physical damage
e. Spacing violation

Metal cases, including those flooded at various water volume fractions, were evaluated double-batched and in most cases stacked $20 \mathrm{high}$ (see discussion in Section 10.2).

2. Accidents for $\mathrm{Pu}$ solution
a. Volume violation (double-batching)
b. Stacking
c. Flooding
d. Sprinkler accident
e. Vehicle accident
f. Spacing violation

Solution cases were evaluated double batched and stacked 3 high.

Mass and volume violations, stacking, sprinkler accidents, and spacing violations are combinable events. However, it was demonstrated that spacing limits are not required.

The highest $k_{\text {eff }}$ calculated for the accidents evaluated was a weighted average of $0.92829 \pm 0.00230$. This was for a vehicle accident in which $60 \mathrm{Pu}$ metal spheres (representing the contents of 60 one-gallon cans) were modeled close-packed and fully reflected. 
NMSL: $\quad 90240$

Engineer: MSOOL 3

Date: December 1991

Page: 1 of 116

\section{APPROVED EQUIPMENT LIST}

In addition to the fissile materials specified in the limits, the following items may be placed inside one-gallon cans:

Plastic bags

Tape

8801 Vollrath cans

8802 Vollrath cans

Glass or plastic sample vials

Temperature indicating devices

Miscellaneous labels 
NMSL: $\quad 90240$

Engineer: MSOOL 3

Date:

December 1991

Page: 8 of 116

\section{EVALUATION ASSUMPTIONS}

The following assumptions were made for the evaluation of RFP one-gallon shipping containers:

\section{Assumptions for Container Representation}

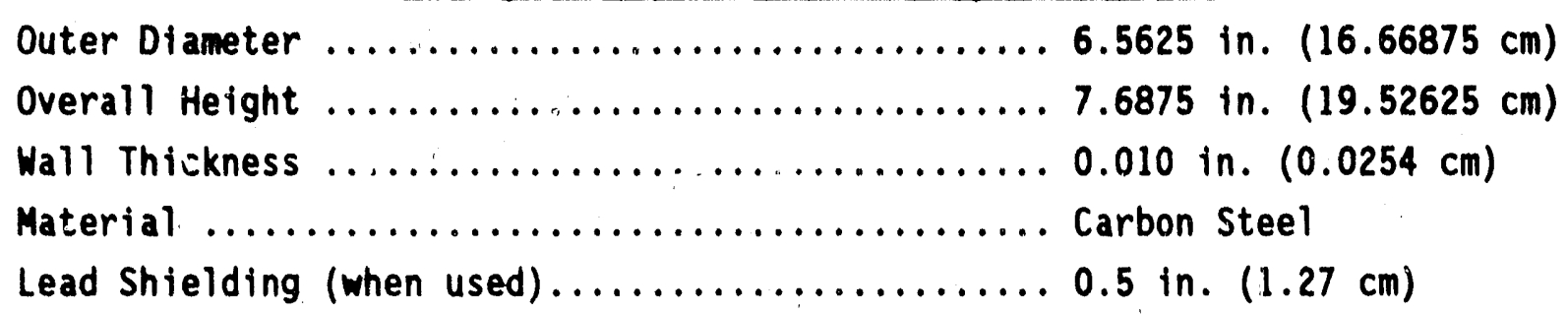

\section{Assumptions for Container Content Representation}

Fissile Material

100 wt.\% U-233 (solid meta), density $18.70 \mathrm{~g} / \mathrm{cc}$ ), all isotopes of uranium are enveloped by $U-233$

or

95 wt.\% Pu-239 and 5 wt.\%

Pu-240, 1000 grams/liter (solution) in 92 vol.\% water, 8 voi.\% polyethylene (Reference 2)

$$
\text { or }
$$

95 wt.\% Pu-239 and 5 wt.\%

Pu-240 or 100 wt. $\%$ U-233, $>1000$ grams/liter (slurry), displacing moderator of 92 vol.\% water and 8 vol.x polyethylene (Reference 2) 
NMSL: $\quad \frac{90240}{1 S 001}$

Engineer: $\mathrm{MSOOI}, 3$

Date:

December 1991

Page: 2 of 116

Moderation (external to fuel)

All degrees of moderation ( $100 \%$ polyethylene or 92 vol.\% water, 8 vol.\% polyethylene at various volume fractions) were evaluated. (See Section 12, Tables 2 and 9.)

Internal Configuration Pu and $U$ metal and slurry spheres offset axially and radially. Pu solution cases in spherical geometry, centered or offset.

\section{Assumptions for Container Configuration}

Container Configuration ................ Close-packed triangular-pitch arrays of containers in planar or stacked configurations. (The closed-packed assumption was demonstrated to be the most reactive configuration.)

Reflection Conservative concrete reflection $30 \mathrm{~cm}$ on top, $60 \mathrm{~cm}$ on bottom.

Moderation All degrees of water moderation between containers. 


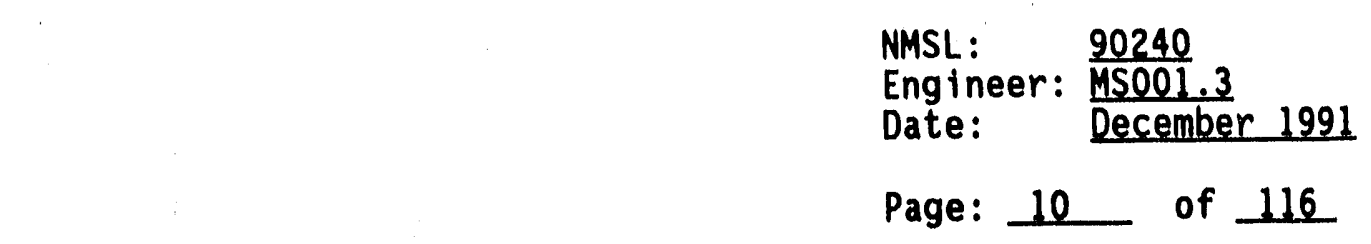

5. REQUIRED CONTROLS AND ENGINEERED SAFETY FEATURES

\subsection{Required Controls}

1. The mass of "dry" plutonium or uranium metal or oxide is 1 imited to 50 grams per one-galion can. A mass 1 imit of 50 grams total, including nonfissile matrix material, applies to metal slurries.

2. The volume of plutonium solutions is limited to $100 \mathrm{ml}$ per one-gallon can regardless of inner containment.

3. The containers must be limited to planar arrays (no stacking).

4. Separation limits between RFP one-gallon containers and other fissile material are not required with the preceding limits on mass, volume, and stacking.

5. A container limit is not required for storage; however, due to the possibility of breaching containers during transport (e.g. in a vehicle accident), the number of containers must be 1 imited to 40 for these operations.

6. Beryllium shall not be placed in one gallon cans containing fissile materials.

\section{j.2 Engineered Safety Features}

There are no engineered safety features which pertain to one gallon cans. 
NMSL: $\quad 90240$

Engineer: MSO01,3

Date: December 1991

Page: 11 of 116

\section{TECHNICAL BASES}

\subsection{Iechnical Bases for Controls}

1. The limit for metal and slurries was evaluated and was shown, as requested, to be acceptable at 50 grams/can. It was possible to show that higher mass values for metal were also safe.

2. The $100 \mathrm{ml}$ volume limit for $\mathrm{Pu}$ solutions $(1000 \mathrm{~g} / 1)$ was selected as the next lower "round" number which results in a $k_{\text {eff }}$ of 0.95 or less with required combined accident scenarios.

3. Without the restriction to planar arrays, stacking to any height becomes a normal condition. Unacceptably high $k_{\text {off }}$ values $(>0.95)$ can result from:

a) Excessive stacking (allowed if this limit is removed) and a single accident (volume, mass or sprinkler violation) - e.g., an infinite array of lead shielded cans combining a mass violation (100 g Pu) and 20 high stacking produced a calculated multiplication factor of $1.041 \pm .005$. (For array sizes $25 \times 24 \times 20$ and $100 \times 100 \times 10$, $k_{\text {eff }}$ values were $0.588 \pm 0.003$ and $0.597 \pm 0.003$, respectively.)

b) Adding stacking to other required accident combinations - e.g.. a volume violation (200 $\mathrm{ml} \mathrm{Pu}$ solution) and sprinkler combination plus stacking 3 high produced a $k_{\text {eff }}$ of $0.964 \pm .003$.

4. Under normal conditions, the effect of having an array of one-gallon cans next to a slab of $\mathrm{Pu}$ solution $\left(k_{\text {eff }} \approx 0.90\right)$ is statistically insignificant. In all cases evaluated with unrealistically large $(25 x$ 50) arrays of cans adjacent the plutonium slab, using the required combinations of two additional events resulted in $k_{\text {eff }}$ values $\leq 0.95$. Based on the calculated results, no spacing requirements are needed.

5. The transport 1 imit ( 40 cans per vehicle) is based on handbook data. Six liters, the contents of 60 cans $(100 \mathrm{ml}$ each), is the minimum critical 
NMSL: $\quad 90240$

Engineer: MSOO1.3

Date: December 1991

Page: 12 of 116

volume for aqueous Pu systems. $80 \%$ of 60 gives a limit of 48 cans, which was rounded down to 40 . The contents of 40 cans for solutions (Ref.3) and 60 cans for metal (Case 1, Table 8) was demonstrated to be safe. A limit of 40 cans was selected for all contents for consistency.

6. Beryllium was excluded from the analysis since it is never expected to be placed in one gallon cans containing Pu or $U$.

\subsection{Technical Bases for ESFs}

There are no engineered safety features which pertain to one gallon cans. 
NMSL: $\quad \frac{90240}{1 S 001}$

Engineer: $\mathrm{MSOO1.3}$

Date: December 1991

Page: 13 of 116

\section{CONCLUSIONS}

Based on the assumptions in Section 4, the 50 gram per can limit on plutonium and uranium metal (dry and in slurries) is safe for the one-galion cans.

A summary of accident case (stacking/mass violation combination) results for plutonium solution calculations is given in Table 1.

TABLE 1. SUMMARY OF RESULTS FOR PU SOLUTION (1000 GRAMS,LITER)

\section{k-effective}

1.0

0.95

0.90
Volume evaluated

$270 \mathrm{ml}$

$230 \mathrm{ml}$

$200 \mathrm{ml}$

Based on the results shown in the table, a $115 \mathrm{ml} / \mathrm{can}$ (one-half of 230 mi) limit is acceptable when double batching is considered. However, because of human factor considerations $(100 \mathrm{ml}$ is easier for an operator to remember than $115 \mathrm{ml}$ ), the recommended operating 1 imit is $100 \mathrm{ml} / \mathrm{can}$ at concentrations no more than $1000 \mathrm{~g} / 1 \mathrm{Pu}$ (mass, not volume, limits are applied to slurries). A stacking restriction (planar arrays oniy) is required for this limit.

The most restrictive limits are imposed on plutonium solutions. Cans containing the plutonium solution require a prohibition on stacking and a transport limit of 40 cans per vehicle. Even though the stacking restriction and the transport limit are less restrictive for metal, to avoid confusion, it is recommended that these limits be applied to all one-gallon containers, regardless of contents.

Spacing restrictions from other fissile material are not required. There is no limit on the number of one-gallon cans in storage arrays. 
NMSL: $\quad 920240$

Engineer: MSOOL 3

Date:

December 1991

Page: 14 of 116

Calculated typical case $k_{\text {eff }}$ values were about 0.05 for $\mathrm{Pu}$ solution (10 $\mathrm{g}$ $\mathrm{Pu} / 1$ ), and around 0.10 to 0.20 for metal and slurry systems (see Section 2). All of these values are so far below code verification benchmark values that their validity is questionable. However, values are included here to comply with requirements and because they provide some indication that there is a considerable margin of safety between typical operating conditions and the accident conditions that were required for the evaluation. Limiting normal case values of about 0.40 to 0.60 (see Section 2) also indicate that criticality safety margins are appreciable.

The vehicle accident model produced the highest $k_{\text {eff }}$, a weighted average of $0.928 \pm 0.002$, which is well below the RFP acceptance criteria of 0.95 . In this mode1 $60 \mathrm{Pu}$ metal spheres were evaluated close-packed and fully water reflected. A substantial margin of safety st 111 exists in the event of this worst case accident scenario. Additional safety margin is provided because the transport limit is set at 40 cans, optimal reflection is unlikely, and credit was not taken for inner containment. 
NMSL: $\quad \frac{90240}{M S 001}$

Engineer: $\mathrm{MSOO1}, 3$

Date: December 1991

Page: 15 of 116

\section{CHECKLISTS}

\subsection{Double Contingency Analys is}

Double Contingency Analysis Form

\section{Failure/Accident Scenario}

Critical assembly of RFP one-gallon containers in storage

\section{Contingencies (Unlikely Events)}

No.
$1^{\star, b} \quad \begin{aligned} & \text { An unrealistically large of array of } \\ & \text { cans accumulated in storage. }\end{aligned}$
$2^{c} \quad \begin{aligned} & \text { Mass limit exceeded in most containers } \\ & \text { by factor of } 2 \text { (metal and slurry) }\end{aligned}$
or

Volume limit exceeded by factor of 2 (solution)

$3^{c} \quad$ Violation of stacking restriction

$1^{\text {b }} \quad$ Physical damage to containers

$2^{c} \quad$ Violation of mass limit (metal or slurry)

\author{
or \\ violation of volume limit (solution) \\ $3^{c} \quad$ Violation of transport limit (number of \\ containers)
}

Critical assembly of RFP one-gallon containers as a result of physical damage to cans during handling or transport

a. Most cases were evaluated as infinite arrays. Limiting array size to 200,000 cans reduced results by $7.2 \%$; limiting to 12,000 cans reduced results by $43 \%$. The number of cans in an array $25 \times 24 \times 20(12,000)$ is still so large that a can limit is not required.

b. Needs no combination.

c. According to RFP requirements this contingency needs to be combined. 
Operation Title: Handling, Shipping and Storage of

Building: Al

Area: Intraplant
NMSL: $\quad 90240$

Engineer: $\mathrm{MSOOJ} .3$

Date: December 1991

Page: 16 of 116

\subsection{Normal Condition Analys is for Shioping Container Operations}

I. Purpose

The purpose of this analysis is to ensure that all normal conditions which could affect criticality safety of onsite shipping container operations are considered and documented.

NOTE: Special care must be exercised for any onsite shipping container that may have dual utility as an onsite and offsite container. An offsite shipping container should not have onsite limits exceeding offsite shipment limits, except in rare, well justified, and specifically documented circumstances.

II. Standard Considerations

A. Reflection due to a human body, walls, floors, etc., on the outside of the containers.

Control Discussion of condition(s) to be considered:

Needed:

\#

Conservative concrete reflection (30 cm on top, $60 \mathrm{~cm}$ on the bottom) was assumed on all infinite planar arrays of cans. Thick concrete reflection envelops other potential reflector conditions due to a human body, etc.

Covered by evaluation case(s): All 
NMSL: $\quad 90240$

Engineer: $\mathrm{MSOOI.3}$

Date: $\quad$ December 1991

Page: 17 of 116

NORMAL CONDITION ANALYSIS

FOR SHIPPING CONTAINER OPERATIONS (cont'd)

\section{Standard Considerations (cont'd)}

B. Use worst case (most reactive) fissile material quantity, densities, geometry, and matrices. NOTE: 1) Be careful about assuming fissile material is centered in the container, unless physical spacers are used to center the material. 2) The full range of allowed fissile material densities must be considered. 3) Gram estimators and counters may be in error so consider an appropriate amount of fissile material as normal conditions. Be sure and consider the aporopriate drum count and estimate errors.

Has the fissile material been placed in the most reactive geometry possible for both single unit and interaction analyses? NOTE: Most reactive geometry for a single unit and for an array may not be the same. Most reactive geometry for arrays may depend strongly on specific units in the array and may vary from case to case.

Control Discussion of condition(s) to be considered:

Needed:

Weapons grade plutonium (95 wt.\% Pu-239 and 5 wt.\% Pu-240) was assumed for calculations. This adequately approximates actual material present during operations. 100 wt.\% U-233 metal envelops all uranium isotopes. Liquid systems were assumed to be 8 Vol.\% polyethylene, 92 Vol.\% water (Ref. 2). This value was based on experimental results for hand packing polyethylene. Water is conservatively assumed to occupy the $92 \%$ of void space. Solutions were modeled as $1000 \mathrm{~g} / 1$ and slurries (sludges) as $5000 \mathrm{~g} / 1$.

Offset spherical geometries were evaluated for dry systems. Solution systems were evaluated with the spherical volume both centered and offset inside the one-galion cans.

For the arrays of one-gallon containers considered in this evaluation, cylindrical geometries are slightly more reactive than spherical geometries. Combinations of spherical geometries and cylindrical shells would be even more reactive. Spherical geometry 
NMSL: $\quad 90240$

Engineer: $\mathrm{MSO01.3}$

Date:

December 1991

Page: 18 of 116

conservatively envelops actual possible geometries considering the types of material placed in one-gallon cans and was assumed in most calculations as a modeling simplification. Selected limiting cases were reported with cylindrical geometries to demonstrate that key calculated values remain below 0.95 for accident conditions and 0.90 for normal operating conditions (See Section 12, Table 8 Cases 3 10).

Beryllium was excluded from the analysis. It is not placed in one gallon cans under normal conditions.

Covered by evaluation case(s): All 
NMSL: $\quad 90240$

Engineer: MSOOL 3

Date: December 1991

Page: 19 of 116

\section{NORMAL CONDITION ANALYSIS \\ FOR SHIPPING CONTAINER OPERATIONS (cont'd)}

II. Standard Considerations (cont'd)

C. True container conditions must be considered (e.g., wall thickness, dimensions and tolerances, internal package components such as shielding or celetex, walls, floors, cellings, etc.). The most conservative dimensions are to be used (thickness, height, radius); these may vary depending on contents. NOTE: A range of package component densities should be evaluated since density of purchased products may vary.

Control Discussion of condition(s) to be considered:

Needed:

$\#$

True container dimensions are given in the assumptions for container representation in Section 4 . Variations of $2 \%$ in the container dimensions had no statistically significant impact on calculated results.

Covered by evaluation case(s): All 
NMSL: $\quad 90240$

Engineer: MSOOL .3

Date: December 1991

Page: 20 of 116

NORMAL CONDITION ANALYSIS

FOR SHIPPING CONTAINER OPERATIONS (cont'd)

II. Standard Considerations (cont'd)

D. Can long-term storage change the form, density, shape, etc., of the fissile material? Will the density change due to thermal conditions (heating and/or cooling)? Will a sludge form due to a change in $\mathrm{pH}$, or salting/sludge result from long-term loss of moderators due to evaluations, leaking, etc.?

Control Discussion of condition(s) to be considered:

Needed:

$\#$

The form, censity and shape of the fissile material are not expected to change with long-term storage; however, near optimum geometries and theoretical metal densities were evaluated to envelop such changes.

Covered by evaluation case(s): All 
NMSL: $\quad 90240$

Engineer: MSOO1.3

Date: December 1991

Page: 21 of 116

NORNAL CONDITION ANALYSIS

FOR SHIPPING CONTAINER OPERATIONS (cont'd)

II. Standing Considerations (cont'd)

E. Has interaction with all other fissile material been considered (adjacent gloveboxes, transfer carts, drums, handcarry materials, etc.)? Most reactive interaction conditions must be considered.

Control Discussion of condition(s) to be considered:

Needed:

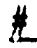

Since all systems at RFP should normally have calculated $k_{\text {eff }}$ values of 0.90 or less, interaction with a slab having a $k_{\text {eff }} \approx 0.90$ was evaluated.

A separation limit is not required.

Covered by evaluation case(s): Section 12 . Table 7 
NMSL: $\quad 90240$

Engineer: $\mathrm{MSOOL}, 3$

Date:

December 1991

Page: 22 of 116

\author{
NORNAL CONDITION ANALYSIS \\ FOR SHIPPING CONTAINER OPERATIONS (cont'd)
}

11. Standard Considerations (cont'd)

F. Make sure the limits for the containers are consistent with further operations. For example, if you allow $\mathbf{4 0 0 0}$ grams to be in one container of one shipping container, you must make sure there are limits for the loading and unloading of $\mathbf{4 0 0 0}$ grams in one container. Consider all locations where the lifits allow use of the container.

Control Discussion of condition(s) to be considered:

Needed:

$\#$

The $50 \mathrm{~g}$ limit on dry fissile material and slurries, and the $100 \mathrm{ml}$ limit on Pu solutions inside RFP one-gallon containers should not present a criticality problem at any location on plant-site where fissile material is allowed.

If one-gallon containers are to be shipped to areas where stricter limits (e.g. Building 559) are imposed for reasons other than criticality safety (e.g. Safeguards and Security Limits) compliance with the stricter limits is required.

Covered by evaluation case(s): Section 12, Tables 2, 4 and 9 
NMSL: $\quad 90240$

Engineer: MSOOL, 3

Date: December 1991

Page: 23 of 116

NORMAL CONDITION ANALYSIS

FOR SHIPPING CONTAINER OPERATIONS (cont'd)

\section{Standard Considerations (cont'd)}

G. The arrangement of containers being evaluated must be combined with the most reactive combination of shipping containers currently approved. This may not be one type of container and contents. Intermixed arrays should be considered. Varied contents and/or varied shipping containers should be considered.

Control Discussion of condition(s) to be considered:

Needed:

$\#$

Near optimum configurations were evaluated. Intermixing of onegallon containers with arrays of other type containers does not increase the reactivity of the array since:

1. The reactivity of a realistic number of one-gallon containers is insignificant (Reference 1, 5.2, Table 2), and

2. Large arrays $(25 \times 50)$ of one-gallon containers next to systems that have calculated $k_{\text {off }}$ values of 0.90 (a value that is much greater than the $k_{\text {eff }}$ values for realistically sized arrays of other containers) resulted in insignificant changes in calculated $k_{\text {eff }}$ values.

3. A stacked infinite array of containers alternating metal and solution as contents resulted in a calculated $k_{\text {eff }}$ of $0.716 \pm$ 0.003 .

Covered by evaluation case(s): Section 12 , Table 7 
NMSL: $\quad 90240$

Engineer: $\mathrm{MSOO1}, 3$

Date: December 1991

Page: 24 of 116

NORMAL CONDITION ANALYSIS

FOR SHIPPING CONTAINER OPERATIONS (cont'd)

11. Standard Considerations (cont'd)

H. The arrangement must consider the ability to hexagonally pack the array of containers.

Control Discussion of condition(s) to be considered:

Needed:

I.

Hexagonally-packed arrays were evaluated.

Covered by evaluation case(s): All 
NMSL: $\quad 90240$

Engineer: $\mathrm{MSOO1}, 3$

Date: December 1991

Page: 25 of 116

NORMAL CONDITION ANALYSIS

FOR SHIPPING CONTAINER OPERATIONS (cont'd)

II. Standard Considerations (cont'd)

I. The array must be evaluated with optimum moderation between the containers. It is possible to have plastics between the containers as a normal condition. If any moderation restrictions must be required, they should be evaluated at varying densities (e.g., al1 plastic in one corner up to homogeneously distributed). Any restrictions must be specified in the 11 mits. NOTE: The array must be evaluated with and without shielding (lead and plastic) allowed by General Comments and specific butlding shielding limits considering the full thickness and density ranges of allowed shielding.

Control Discussion of condition(s) to be considered:

Needed:

All degrees of moderation were evaluated. Conservative concrete reflection $(30 \mathrm{~cm}$ on the top and sides, $60 \mathrm{~cm}$ on the bottom) was assumed.

A 92 vol.\% water, 8 vol.\% polyethylene composition was used as a moderator. This accounts for the maximum amount of polyethylene that can be hand packed between or inside of the one-gallon containers (Reference 2).

Lead shielding was also evaluat:d (see III, A.).

Covered by evaluation case(s): All 
NMSL: $\quad 90240$

Engineer: MSOOI.3

Date:

December 1991

Page: 26 of 116

NORMAL CONDITION ANALYSIS

FOR SHIPPING CONTAINER OPERATIONS (cont'd)

II. Standard Considerations (cont'd)

J. Other items to be considered. Attach a draft copy of the nuclear materials safety 11 mit to ensure all normal conditions have been considered.

Control Discussion of condition(s) to be considered:

Needed:

\#

See Section 13.

Covered by evaluation case(s): All 
NMSL: $\quad 90240$

Engineer: $\mathrm{MSOOL}, 3$

Date:

December 1991

Page: 27 of 116

NORMAL CONDITION ANALYSIS

FOR SHIPPING CONTAINER OPERATIONS (cont'd)

\section{General Comments}

A. Has the $1 / 2^{n}$ lead and $1 / 8^{n}$ neutron shielding been added to the containers? (Reference Section II, Item I)

Control Discussion of fallure(s) to be considered:

Needed:

In all plutonium cases evaluated, additional polyethylene moderator inside the container tended to isolate adjacent containers and reduce the $k_{\text {ff }}$ of the array. Uranium metal showed slight increases in the multipification factor with low density moderator between the cans (See Table 9). Limits were based on the most reactive cases.

The addition of $1 / 2^{\prime \prime}$ lead shielding increased $k_{\text {eff }}$ 's slightly. The $k_{\text {ff }}$ 's of infinite arrays of cans containing metal or slurry, stacked $20 \mathrm{high}$ and double-batched to $100 \mathrm{~g}$ per can (1 imiting accident case), were slightly greater than 1.0 . Stacks up to 15 high containing $U$ metal remained below $0.95 \mathrm{k}$-effective $10.930 \pm$ 0.004 ) with or without the addition of this shielding : See Table 10). Double-batched cans with lead shielding stacked three high resulted in $k_{\text {eff's }}$ less than 0.95 for all materials of concern. Since the stacking prohibition is applied to one gallon cans regardless of contents, no criticality safety problem is anticipated.

Covered by evaluation case(s): Section 12: Table 2. Cases 17 and 19: Table 5 Case 17: and Table 10 
NMSL: $\quad 90240$

Engineer: MSOOL, 3

Date: $\quad$ December 1991

Page: 28 of 116

NORMAL CONDITION ANALYSIS

FOR SHIPPING CONTAINER OPERATIONS (cont'd)

III. General Comments (cont'd)

B. All oxide or compound evaluations must have 10 wt. $\% \mathrm{H}_{2} \mathrm{O}$ added as a normal condition.

Control Discussion of failure(s) to be considered:

Needed:

Liquid systems were evaluated with 8 Vol.\% polyethylene - 92 Vol.\% water (Ref. 2).

Oxides and compounds are conservatively enveloped by metal. Calculations indicate that the $k_{\text {eff }}$ decreases from $0.767 \pm 0.002$ for metal to $0.720 \pm 0.002$ for an equal mass of Pu oxide with 10 wt.\% $\mathrm{H}_{2} \mathrm{O}$.

Covered by evaluation case(s): All 
NMSL: $\quad 90240$

Englneer: MSOO1, 3

Date: December 1991

Page: 29 of 116

NORMAL CONDITION ANALYSIS

FOR SHIPPING CONTAINER OPERATIONS (cont'd)

III. General Comments (cont'd)

C. Other bullding specific General Comments. NOTE: Approprlate General Comments considered and discussed below.

Control Discussion of failure(s) to be considered:

Needed:

None

Covered by evaluation case(s): N/A 
Operation Title: Handling. Shtpping and Storage of

Butlding: REP One-Gallon Containers

Area: Intraplant
NMSL: $\quad 90240$

Engineer: MSOOL, 3

Date: December 1991

Page: 30 of 116

\subsection{Eallure Analys is Checksheet for Shipoing Container Operations}

\section{Purpose}

The purpose of this analysis is to ensure that all possible fallures which could affect criticality safety of shipping container operations are considered and documented.

II. Operator Error

A. Multiple Batching

Can the fissile material be multiple batched? If so, by how much? CAUTION: If an operator over batches one container, it is likely he or she will over batch more than one, unless there are specific controls to prevent such multiple batching.

Control Discussion of fallure(s) to be considered:

Needed:

A single container could be overbatched by a considerable factor. Large arrays $(50 \times 25 \times 3)$ of cans with a single heavily loaded can [500 $\mathrm{g}$ metal (factor of 10 times the $11 \mathrm{mit}$ ) or $4224 \mathrm{ml}$ solution (full can)] were evaluated. The highest $k_{\text {eff }}$ determined by the calculations was $0.580 \pm 0.003$ for the Pu solution.

Uniform double-batching (overbatching by a factor of 2) of all containers was evaluated. Overbatching by more than a factor of 2 is not credible due to stringent safeguards and security measures in the RFP material handing procedures. It is implausible that a sufficient amount of material would be accessible to overbatch a large array of cans by more than a small amount in each can. Additional personnel would become involved in any transfer procedures for filled containers, and accountability requirements make it extremely unlikely that serious overbatching of large numbers of cans would go unnoticed long enough to cause a criticality safety concern.

Covered by evaluation case $(s)$ : Section 12, Tables 2,4, and 9 
NMSL: $\quad 90240$

Engtneer: $\mathrm{MSOO}_{1} 3$

Date: December 1991

Page: 31 of 116

FAILURE ANALYSIS CHECKSHEET

FOR SHIPPING CONTAINER OPERATIONS (cont'd)

II. Operator Error (cont'd)

B. Spacing Violation of Handcarry Limits

Can one or more containers or ttems be brought next to other equipment, such as tanks? If so, how many? CAUTION: If an operator violates one spacing, they could violate all spacing restrictions.

Control Discussion of fallure(s) to be considered:

Needed:

$\#$

It was shown that separation limits are not required. (See Section 10).

Covered by evaluation case(s): Section 12. Table 7 
NMSL: $\quad 90240$

Eng ineer: MSO01,3

Date:

December 1991

Page: 32 of 116

FAILURE ANALYSIS CHECKSHEET

FOR SHIPPING CONTAINER OPERATIONS (cont'd)

II. Operator Error (cont'd)

C. What if the operation is left unattended? What effect would long-term neglect have on the operation? for example, leaving containers open under liquid lines and a water leak filling the containers could lead to a criticality safety concern.

Control Discussion of fallure(s) to be considered:

Needed:

\#

Near optimal conditions have been considered. Flooding increased the neutron multiplication factor in some cases and this was considered in establishing the limits.

Covered by evaluation case(s): Section 12: Table 2 Case 10: Table 5, Cases 1.7 , and 14-16 
NMSL: $\quad 90240$

Engineer: $\mathrm{MSOOL}, 3$

Date: December 1991

Page: 33 of 116

FAILURE ANALYSIS CHECKSHEET

FOR SHIPPING CONTAINER OPERATIONS (cont'd)

II. Operator Error (cont'd)

D. Transfer Errors: Can the shipping container be transferred to an area which would be unsafe, or where area limits will be violated (e.g., tank farms, vaults, etc.)?

Control Discussion of fallure(s) to be considered:

Needed:

RFP one-galion containers could probably be shipped to areas where area limits would be violated; however, interaction with other fissile material has been conservativeiy evaluated and it was shown that separation limits are not required.

Covered by evaluation case(s): Section 12. Table 7 
NMSL: $\quad \frac{90240}{M S 001}$

Engineer: MSOO1.3

Date:

December 1991

Page: 34 of 116

FAILURE ANALYSIS CHECKSHEET

FOR SHIPPING CONTAINER OPERATIONS (cont'd)

II. Operator Error (cont'd)

E. What if an operator adds additional shielding around the containers. For example, poly walls might be stacked around one or more containers to reduce exposure.

Control Discussion of fallure(s) to be considered:

Needed:

\#

Thick concrete reflection on top $(30 \mathrm{~cm})$ and bottom $(60 \mathrm{~cm})$ of the array envelops other potential normal and off-normal reflector conditions external to the array of one-gallon containers. Finite arrays of cans were reflected by $30 \mathrm{~cm}$ of concrete on the sides also.

All degrees of polyethylene and water moderation between and inside cans were evaluated.

Covered by evaluation case(s): All 
NMSL: $\quad 90240$

Engineer: MSOO1.3

Date: December 1991

Page: 35 of 116

FAILURE ANALYSIS CHECKSHEET

FOR SHIPPING CONTAINER OPERATIONS (cont'd)

II. Operator Error (cont'd)

F. Consider stacking accident where more containers are stacked than allowed (even if no stacking is allowed).

Control Discussion of fallure(s) to be considered:

Needed:

if

Stacking at least 3 high was considered and limits were established based on a violation of stacking restrictions. Stacking 3 high is considered adequate since limits require a restriction to planar arrays only (no stacking). Physical size of the cans and the instability of stacks makes arrays more than 3 high unrealistic.

Metal cases were modeled as an array stacked $20 \mathrm{high}$. This is considered unrealistic, but eliminates concern over stacking 1 imits and the need to consider stacking accidents for metal.

Covered by evaluation case(s): Section 12 . Tables 2,4 , and 9 
NMSL: $\quad 90240$

Engineer: $\mathrm{MSOO1.3}$

Date:

December 1991

Page: 36 of 116

FAILURE ANALYSIS CHECKSHEET

FOR SHIPPING CONTAINER OPERATIONS (cont'd)

II. Operator Error (cont'd)

G. Can this container be mistaken for another and loaded with an unacceptable amount of material approved for the shipping container that the operator thought he/she was filling (e.g., 35 gallon versus $55 \mathrm{~g}$ ? $10 \mathrm{n})$ ?

Control Discussion of failure(s) to be considered:

Needed:

$\#$

It is unlikely that RFP one-gallon containers could be mistaken for another type of container. However, the cans were shown to remain safely subcritical in the event that all containers are uniformly double-batched.

Covered by evaluation case(s): Section 12, Table 2, 4, and 9 
NMSL: $\quad \frac{90240}{1 S 001}$

Engineer: MSOO1.3

Date: December 1991

Page: -37 of 116

FAILURE ANALYSIS CHECKSHEET

FOR SHIPPING CONTAINER OPERATIONS (cont'd)

\section{Operator Error (cont'd)}

H. Can mislabeling the shipping container lead to criticality safety concerns (e.g.. supercompactor, two-high stacking, etc.)?

Control Discussion of fallure(s) to be considered:

Needed:

The most reactive configuration under accident conditions would be for the contents of all cans to be combined in one location. The minimum critical volume for spherical aqueous systems of $\mathrm{Pu}-239$ is greater than 6 liters. With $100 \mathrm{ml}$ per can, the minimum number of cans that can combine to form a critical volume is 60 . Cans being shipped to the supercompactor would be 1 imited to 40 by the transport limit, so there would not be sufficient material present for criticality.

For dry systems, the contents of 60 double-batched cans, modeled as 100 gram spheres (close-packed and water reflected), were shown to be have a $k_{\text {eff }}$ below $0.95(0.928 \pm 0.002$ for Pu metal. [U-233 metal was less reactive $(0.842 \pm 0.005)$ and is not reported in the table.] Therefore, inadvertently directing the cans to the supercompactor does not result in a criticality concern.

Stacking at least three high was evaluated.

Covered by evaluation case(s): Section 12, Table 8, Case 1 
NMSL: $\quad \frac{90240}{\text { MSO01 }}$

Engineer: MSOO1.3

Date: $\quad$ December 1991

Page: 38 of 116

FAILURE ANALYSIS CHECKSHEET

FOR SHIPPING CONTAINER OPERATIONS (cont'd)

II. Operator Error (cont'd)

I. Truck wreck and pileup must be considered. This should include any possible damage to containers or packing material.

Control Discussion of fallure(s) to be considered:

Needed:

\#

The most reactive configuration under accident conditions would be for the contents of all cans to be combined in one location. The minimum critical volume for spherical aqueous systems of Pu-239 is greater than 6 liters (Ref. 3). With $100 \mathrm{ml}$ per can, the minimum number of cans that can combine to form a critical volume is 60 .

For dry systems, the contents of 60 double-batched cans ( $100 \mathrm{~g}$ each), in a close-packed array of uncontained, fully water-reflected spheres were shown to have a $k_{\text {eff }}$ below $0.95(0.928 \pm 0.002$ for $\mathrm{Pu}$ metal. [ $U-233$ metal was less reactive $(0.842 \pm 0.005)$ and is not reported in the table.]

Conservatism in applying the $80 \%$ of critical rule (Reference 4$) \quad(60$ $x .8=48$ cans, and rounding down to a round number) suggests that the number of cans be limited to 40 during transportation.

Covered by evaluation case(s): Section 12, Table 8, Case 1 
NMSL: $\quad 90240$

Engineer: MSOO1.3

Date: December 1991

Page: 39 of 116

FAILURE ANALYSIS CHECKSHEET

FOR SHIPPING CONTAINER OPERATIONS (cont'd)

II. Operator Error (cont'd)

J. Has the use of improper inner containers been considered (e.g., loss of spacing, changing in geometry, inner container restrictions, etc.)?

Control Discussion of failure(s) to be considered:

Needed:

$\#$

This analysis is not dependent on inner containment. Worst case configurations inside the containers were assumed. These configurations envelop conditions where inner containers are present.

Covered by evaluation case(s): All 
NMSL: $\quad 90240$

Engineer: MSOOI.3

Date:

December 1991

Page: 40 of 116

FAILURE ANALYSIS CHECKSHEET

FOR SHIPPING CONTAINER OPERATIONS (cont'd)

II. Operator Error (cont'd)

K. Other operator errors.

Control Discussion of fallureis) to be considered:

Needed:

\#

None

Covered by evaluation case(s): N/A 


\section{NMSL: $\quad 90240$}

Engineer: $\mathrm{MSOO1}, 3$

Date: December 1991

Page: 41 of 116

FAILURE ANALYSIS CHECKSHEET

FOR SHIPPING CONTAINER OPERATIONS (cont'd)

III. Equipment Failures

A. Can various thermal conditions affect criticality safety? For example, heating and/or cooling the container contents may change concentration to an unsafe level.

Control Discussion of fallure(s) to be considered:

Needed:

$\#$

No, optimal or near optimal conditions were assumed.

Covered by evaluation case(s): N/A 
NMSL: $\quad 90240$

Engineer: MSOOL 3

Date: December 1991

Page: 42 of 116

\section{FAILURE ANALYSIS CHECKSHEET \\ FOR SHIPPING CONTAINER OPERATIONS (cont'd)}

III. Equipment Failures (cont'd)

B. Be sure and consider one or more containers rupturing or leaking.

Control Discussion of fallure(s) to be considered:

Needed:

\#

Ruptured containers would result in a less reactive geometry if the contents spreads out over a larger volume. With the mass, volume, and number of containers (40) allowable during transport, accumulation into near optimal geometry is still safely subcritical.

Puncturing large numbers of cans during storage is considered very unlikely. The additional improbability of having a large volume of material (the contents of more than 40 cans) accumulate in an optimally moderated and reflected geometry makes a critical scenario from this type of accident incredible.

Covered by evaluation case(s): Section 12 , Table 8 and Handbook data 
NMSL:

Engineer: $\mathrm{MSOO1}, 3$

Date:

December 1991

Page: 43 of 116

FAILURE ANALYSIS CHECKSHEET

FOR SHIPPING CONTAINER OPERATIONS (cont'd)

III. Equipment Failures (cont'd)

C. Standard failure of the counting equipment.

Control Discussion of fallure(s) to be considered:

Needed:

\#

Uniform double-batching (overbatching by a factor of 2) of al1 containers was evaluated. Overbatching by more than a factor of 2 is not credible due to stringent safeguards and security measures in the RFP matertal handling procedures. It is implausible that a sufficient amount of material would be present to overbatch a large array of cans by more than a small amount per can. (See page 30.)

Covered by evaluation case(s): Section 12 , Tables 2 and 4 
NMSL: $\quad 90240$

Englneer: $\mathrm{MSOOL}, 3$

Date: December 1991

Page: 44 of 116

FAILURE ANALYSIS CHECKSHEET

FOR SHIPPING CONTAINER OPERATIONS (cont'd)

\section{Equipment Fallures (cont'd)}

D. Can the dimensions of the container change due to change in pressure (positive or negative) or damage during transport?

Control Discussion of fallure(s) to be considered:

Needed:

\#

The most reactive configuration under accident conditions (damage during transport) would be for the contents of all cans to be combined in one location. The minimum critical volume for spherical aqueous systems of Pu-239 is greater than 6 1iters. With $100 \mathrm{ml}$ per can, the minimum number of cans that can combine to form a critical volume is 60 . Spreading out the contents would lower the $k_{\text {eff }}$ *

For dry systems, the close-packed contents of 60 double-batched cans $\left(100 \mathrm{~g}\right.$ each) were shown to have a $k_{\text {eft }}$ below $0.95(0.928 \pm 0.002$ for Pu metal, $0.842 \pm 0.005$ for $U-233$ metal).

Since transport of one-gallon cans is 1 imited to 40 , a change in can dimensions will not result in the accumulation of sufficient material (nor would the material be optimally moderated and reflected) to produce excessively high $k_{\text {off }}$ values.

During storage there is no known mechanism that could overpressure and breach a large number of cans. Therefore, storage areas need not be restricted to a limited number of containers.

Covered by evaluation case(s): Section 12 . Table 8 . Case 1 
NMSL: $\quad 90240$

Eng ineer: MSOOL 3

Date:

December 1991

Page: 45 of 116

\section{FAILURE ANALYSIS CHECKSHEET \\ FOR SHIPPING CONTAINER OPERATIONS (cont'd)}

III. Equipment Fatlures (cont'd)

E. Other equipment fallures.

Control Discussion of fallure(s) to be considered:

Needed:

$\#$

None

Covered by evaluation case(s): N/A 
NMSL: : ...... 90240

Engtneer: MSOO1,3

Date: December 1991

Page: 46 of 116

FAILURE ANALYSIS CHECKSHEET

FOR SHIPPING CONTAINER OPERATIONS (cont'd)

IV. Fire Fallures

A. Sprinkler activation inside and outside of the containers.

Control Discussion of fallure(s) to be considered:

Needed:

\#

A11 degrees of water moderation were evaluated.

Covered by evaluation case(s): Section 12: Table 2. Cases 10-13, Table 5, Cases 1-16 
NMSL: $\quad 90240$

Engtneer: MSOOL, 3

Date: December 1991

Page: 47 . of 116

FAILURE ANALYSIS CHECKSHEET

FOR SHIPPING CONTAINER OPERATIONS (cont'd)

IV. Fire Fatlures (cont'd)

B. Is full flooding possible? CAUTION: Doorways and dams may not be able to handle volumes of water that might be added by a number of firemen using hoses; therefore, pits and basements must be considered flooded.

Control Discussion of fallure(s) to be considered:

Needed:

$\#$

Full flooding is unlikely; however, all degrees of water moderation and full concrete reflection were evaluated.

Covered by evaluation case(s): Section 12: Table 2, Cases 10-13 Table 5 , Cases $1-16$ 
NMSL: $\quad 90240$

Eng ineer: $\mathrm{MSOO1.3}$

Date: December 1991

Page: 48 of 116

FAILURE ANALYSIS CHECKSHEET

FOR SHIPPING CONTAINER OPERATIONS (cont'd)

IV. Fire Failures (cont'd)

C. Can a fire result in a loss of moderation, structural, or poison materials? For example, internal packaging materials.

Control Discussion of fallure(s) to be considered:

Needed:

Changes resulting from fire damage are enveloped by the near optimal conditions assumed.

Covered by evaluation case(s): N/A 
NMSL: $\quad 90240$

Engineer: MSOO1, 3

Date: December 1991

Page: 49 of 116

FAILURE ANALYSIS CHECKSHEET

FOR SHIPPING CONTAINER OPERATIONS (cont'd)

IV. Fire Fatlures (cont'd)

D. Can a fire result in warpage of the container which could result in a criticality safety problem?

Control Discussion of fallure(s) to be constdered:

Needed:

$\#$

Damage to containers may occur, but would not result in a criticality safety problem because optimal configurations were assumed and were shown to be safely subcritical $\left(k_{\text {eff }}<0.95\right)$.

Covered by evaluation case(s): $N / A$ 
NMSL: $\quad 90240$

Engineer: $\mathrm{MSOO1}, 3$

Date: December 1991

Page: 50 of 116

FAILURE ANALYSIS CHECKSHEET

FOR SHIPPING CONTAINER OPERATIONS (cont'd)

IV. Fire Fallures (cont'd)

E. Can the solution be boiled down or the material geometry change to an unsafe concentration or configuration?

Control Discussion of fallure(s) to be considered:

Needed:

$\#$

Spherical geometry was assumed. More realistic geometries that could result from melting, etc. are less reactive. If liquid evaporates from solution systems, the conditions will approach those evaluated for the metal cases.

Covered by evaluation case(s): All 
NMSL: $\quad \frac{90240}{\text { ESOO1 }}$

Engineer: MSOO1.3

Date: December 1991

Page: 51 of 116

FAILURE ANALYSIS CHECKSHEET

FOR SHIPPING CONTAINER OPERATIONS (cont'd)

IV. Fire Fallures (cont'd)

F. Can fire change the composition of fissile materiai approved for the limit (e.g., metal shapes to piled oxide, dissolution into heated firewater, etc.)?

Control Discussion of fallure(s) to be considered:

Needed:

$\#$

Yes, but those changes were enveloped by the evaluation (i.e., oxides were enveloped by metal and slurries).

Covered by evaluation case(s): All 
NMSL: $\quad 90240$

Engineer: MSO01.3

Date:

December 1991

Page: 52 of 116

FAILURE ANALYSIS CHECKSHEET

FOR SHIPPING CONTAINER OPERATIONS (cont'd)

\section{Earthquakes}

A. Consider the breakage of all supports or a worst case condition of only a certain number of supports breaking. NOTE: Redesign may be necessary such that supports meet the design basis earthquake (DBE) event.

Control Discussion of failure(s) to be considered:

Needed:

N

Enveloped by the evaluation (tight-fitting concrete reflector).

Covered by evaluation case(s): N/A 
NMSL: $\quad 90240$

Engineer: MSO01,3

Date: $\quad$ December 1991

Page: 53 of 116

FAILURE ANALYSIS CHECKSHEET

FOR SHIPPING CONTAINER OPERATIONS (cont'd)

V. Earthquake (cont'd)

B. Pileup of containers or loss of spacing due to DBE.

Control Discussion of failure(s) to be considered: Needed:

\#

Close-packed hexagonal geometry, stacking at least 3-high, and tight fitting concrete reflection were evaluated.

Covered by evaluation case(s): Section 12 , Tables 2 and 4 
NMSL: $\quad 90240$

Engineer: $\mathrm{MSOO1}, 3$

Date:

December 1991

Page: 54 of 116

FAILURE ANALYSIS CHECKSHEET

FOR SHIPPING CONTAINER OPERATIONS (cont'd)

VI. Other Accident Conditions to be Considered None

Covered by evaluation case(s): N/A 
Operation Title: Handling. Shipping and Storage of Butlding: All RFP One-Gallon Containers

Area: Intraplant
NMSL: $\quad 90240$

Engineer: $\mathrm{MSOO1.3}$

Date: December 1991

Page: 55 of 116

\subsection{Evaluation Needs Analys is}

\section{Purpose}

The purpose of this analysis is to prepare for the calculations by defining the normal and accident conditions to be evaluated. Once defined, each of these cases should be ordered from "Expected Most Reactive" to "Expected Least Reactive" and the resulting list of cases examined to eliminate any superfluous calculations.

II. Normal Case Conditions

Normal operating conditions for storage of RFP one-gallon shipping containers were modeled as infinite arrays of containers with $50 \mathrm{~g}$ "dry" plutonium or uranium metal, $50 \mathrm{~g}$ of plutonium or uranium slurry (sludge), or $100 \mathrm{ml}$ plutonium solution per container. The array is reflected on top by $30 \mathrm{~cm}$ of concrete and on bottom by $60 \mathrm{~cm}$ of concrete. Calculated $k_{\text {eff }}$ values of $0.534 \pm 0.002,0.629 \pm 0.003$, and $0.392 \pm 0.002$ resulted for normal condition plutonium "dry" metal, Pu slurry, and Pu solution systems, respectively. The U-233 normal case produced a calculated $k_{\text {eff }}$ of $0.572 \pm 0.004$ for metal and $0.458 \pm 0.003$ for slurry. All of these values are much less than 0.90 . 
NMSL: $\quad 90240$

Engineer: $\mathrm{MSOO1}, 3$

Date:

December 1991

Page: 56 of 116

\section{EVALUATIONS NEEDS ANALYSIS}

III. Accident Case Conditions

1. Mass or Volume Limit Violation (Factor of 2)

2. Flooding (need not be combined)

3. Sprinkler Violation

4. Stacking Violation

5. Spacing Violation

6. Physical Damage to Containers (breach or compaction due to vehicle accident, earthquakes, etc., need not be combined)

Accident or Event

1 and $2^{\circ}$

1 and 3

1 and 4

1 and 5

1 and 6

2 and 3

2 and 4

2 and 5

2 and 6

3 and 4

3 and 5

3 and 6
Case Number(s) or Report Section(s)

Case 10 of Table 2; Cases 1, 7, 14, 15, and 16 of Table 5 , Cases 9 and 10 of Table 9

Cases 10-13 of Table 2, Cases 1-6 of Table 5, Cases 1115 of Table 9

Cases 1-15 and 17-19 of Table 2, Cases 1-7 of Table 4, Case 17 of Table 5, Cases $1-15,17$ and 18 of Table 9

Case 3, Table 7

$N / A$, combined events do not apply to damaged container accidents

$N / A$

N/A

N/A

$N / A$, potential common mode failure

Cases 10-13 of Table 2, Cases 7-12 of Table 5, Cases 1015 of Table 9

Case 8, Table 7

Potential common mode failure; enveloped by events 2 and 6 
NMSL: $\quad 90240$

Engineer: MSOOL, 3

Date: December 1991

Page: 57 of 116

Accident Case Conditions, continued.

Accident or Event Case Number(s) or Report Section (s)

4 and 5

Case 4, rable 7

4 and 6

$N / A$, potential common mode fallure

5 and 6

N/A

a. This combination was not required; however, since it was conveniently evaluated and shown safe, results are included in the report. 


$$
\begin{aligned}
& \text { NMSL: } \\
& \text { Engineer: } \frac{90240}{\text { MSO01 } 3} \\
& \text { Date: } \\
& \text { Pecember } 1991 \\
& \text { Page: } 58 \text { of } 116
\end{aligned}
$$

\section{REFERENCES}

1. J. B. Briggs, Criticality Safety Evaluatton of Rocky Flats Plant One-Gallon Shipoing Containers, EGG-NE-9518, February 1991

2. J. Painter, evaluation for DOT SP-5948/ATMX-600, March 1986.

3. J. T. Thomas, Ed. Nuclear Safety Guide, TID-7016, Rev. 2, June 1978.

4. G. L. Twaed, Nuclear Safety Lepartment Procedure, iriticality Safety Evaluation, 3-NSPPM-5B-01, Rev. 4, E. G. \& G, Rocky Flats, October 21, 1991.

5. L. M. Petrie and N. F. Landers, KENO-Y.a - An Improved Monte Carlo Criticality Program with Supergrouping, NUREG/CR-0200, Oak Ridge National Laboratory, December 1984. 
NMSL: $\quad 90240$

Engtneer: $\mathrm{MSOOL1,3}$

Date: December 1991

Page: 59 of 116

\section{DISCUSSION}

\subsection{Codes, Cross Sections and Validations}

A discussion of benchmark calculations for the KENO-V. a code is included in Section 4 of Reference 1. These calculations were performed on an IBM RISC 6000 workstation, therefore, the benchmark calculations were repeated for system verification. Since all metal systems are included in this report, but were not included in Reference 1, plutonium (JEZEBEL) and U-233 (JEZ-23) metal critical experiments, were also evaluated. The following results were obtained:

\begin{tabular}{llrl}
$\begin{array}{c}\text { Benchmark } \\
\text { ID }\end{array}$ & \multicolumn{1}{c}{ Description } & $H / X$ & $\begin{array}{c}\text { KENO } \\
\text { Calculated } \\
k \pm \sigma\end{array}$ \\
\cline { 2 - 2 } & Bare sphere & 700 & $1.004 \pm 0.003$ \\
PNL-2 & Bare sphere & 131 & $1.012 \pm 0.004$ \\
PNL-3 & Bare sphere & 1204 & $0.996 \pm 0.003$ \\
PNL-4 & Bare sphere & 911 & $1.007 \pm 0.003$ \\
PNL-5 & Bare sphere & 578 & $1.003 \pm 0.003$ \\
PNL-7 & Reflected sphere & 980 & $1.002 \pm 0.003$ \\
JEZEBEL & Bare sphere & 0 & $1.002 \pm 0.004$ \\
JEZ-23 & Bare sphere & 0 & $1.002 \pm 0.004$
\end{tabular}

Metal, slurry, and solution systems were evaluated separately. The three material types are discussed in the remainder of this section. 
NMSL: $\quad 90240$

Engtneer: $\mathrm{MSOOL}, 3$

Date: December 1921

Page: 60 of 116

\subsection{Dry Uranium and Plutonfum Metal}

Dimensions and materials for the one-gallon cans are identical to those used in the initial evaluation (page 2 of Reference 1) and are given in Section 3 of this report. Densities of 19.84 and 18.70 grams/cc were used to calculate the volume of plutonium and uranium metal, respectively. Atom densities for plutonium metal were calculated for 95 wt.\% Pu-239 and 5 wt.\% Pu-240. Urantum was evaluated as $100 \mathrm{wt} . \%$ U-233.

In order to establish a 50 gram per can $11 \mathrm{mlt}$, arrays of containers were modeled double-batched to 100 grams per can. Varlous degrees of moderation/reflection inside and between containers were used; however, moderator matertal was not intermixed with the plutonium or uranium (except for slurries, Section 10.4). KENO-V.a results indicated that arrays of containers containing dry plutonium metal are more reactive without polyethylene or water moderation/reflection inside and between containers. The highest calculated $k_{\text {off }}$ for Pu was $0.767 \pm 0.004$. The results are tabulated in Table 2 and shown graphically in Figure 2. For U-233 the highest $k_{\text {eff }}$ was $0.827 \pm 0.002$ (Case 14 of Table 9) with 0.05 water volume fraction between cans.

The spherical fuel was offset axtally and radially to the edge of the can. Offsetting the fuel results in the fuel spheres being clustered in groups. Accordingly, they are closer to each other than they would be if centered in the container (Figure 1). Preliminary calculations confirmed that offset fuel configurations were more reactive than those with centered fuel. In the two cases evaluated using an alternative unit cell, it was shown that the change had no impact on the $k_{\text {off }}$. (Table $3,1 a$ and $13 a$ ). It is recognized that other geometries (1.e., shell type geometries) may be more reactive when represented in arrays of containers; however, the offset spherical geometry used is considered sufficiently conservative for the type of materials that will be placed inside one-gallon containers (See page 17 and Section 12, Table 8). 
NMSL:

90240

Engtneer: $\mathrm{SOOO}, 3$

Date:

December 1991

Page: 61 of 116

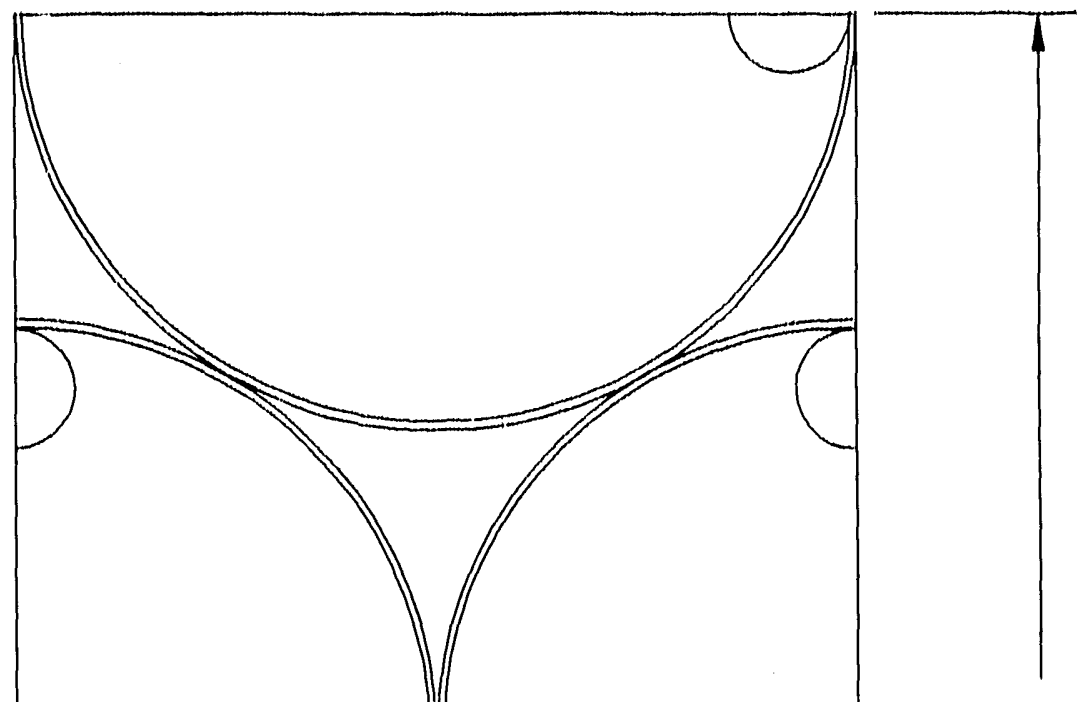

$28.8712 \mathrm{~cm}$

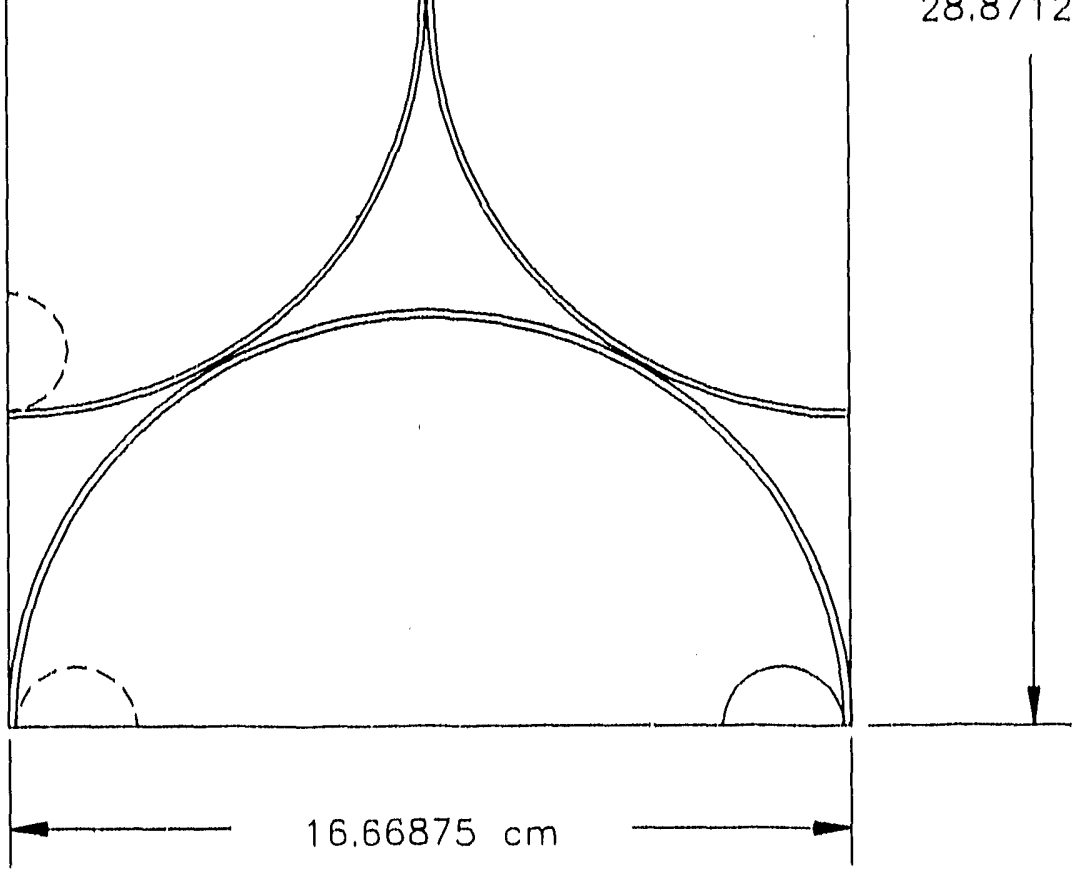

-...- alternate configuration

1040-MLs-0081-02

Figure 1. Unit cell used for representing arrays of cans with offset fuel. 
NMSL: $\quad 90240$

Engtneer: MSOOL, 3

Date: December 1991

Page: 62 of 116

Arrays of cans containing uranium and plutonium metal were run with infinite mirror reflection in the $x$ and $y$ planes and stacked 20 high $(12.8$ $\mathrm{ft}$ ). Stacking is not the normal operating condition but it was initially expected that this model would eliminate the need to evaluate stacking as an accident case for metal only. However, twenty high stacking was a 1 imiting factor in cases using cans containing lead shielding. Stacking 20 high is considered overly conservative, but because lead shielding increaseis reactivity, the stacking prohibition must apply to all one-gallon cans regardless of contents even though lower stacks, up to $15 \mathrm{high}$, were shown to be acceptable (Table 10).

Accident cases for the "dry" metal included overbatching, flooding, sprinkler and physical damage to containers. The first three accidents are reported in Cases 1 through 13 of Tablas 2 and 3 , and in Table 9. A sprinkler accident case for Pu with a water volume fraction of 0.1 between cans (Case 13, Table 2) produced the highest $k_{\text {eff }}(0.750 \pm 0.004)$ for "flooded" conditions. The highest value for $U-233$ was $0.827 \pm 0.002$ as reported earlier in this section.

The physical damage accident (vehicle accident, earthquake, breach of container,etc.) was modeled using a close packed "pile" of 100 gram spheres of plutonium metal with effectively infinite water reflection. Sixty of the 100 gram spheres resulted in a $k_{\text {eff }}$ Just below 0.95 (Table 8, Case 1). Modeling 12550 gram spheres and separating the spheres away from the close packed arrangement lowered the $k_{\text {eff }}$ (Cases 2 and 3 of Table 8). U-233 was less reactive than $\mathrm{Pu}$ in this model.

The possibility of removing administrative spacing requirements (from other fissile material) was also evaluated. This was accomplished by representing a fully water reflected slab of plutonium solution $\left(k_{\text {eff }}=0.891 \pm\right.$ 0.004 , Ref. 1, p. 31) next to a planar array of double-batched cans (see Case 1 of Table 7). The resulting $k_{\text {off }}(0.890 \pm 0.002)$ indicates that the arrangement has minimal impact on the $k_{\text {eff }}$ of the system. An array of single-batched cans, stacked 3 high, next to the slab resulted in a similar value for $k_{\text {eff }}(0.804 \pm 0.002$, Case 2 cf Table 7). Double-batched cans 
NMSL: $\quad 90240$

Eng ineer: $\mathrm{MSOOL}_{3} 3$

Date: December 1991

Page: 63 of 116

stacked three high next to the slab gave a calculated $k_{\text {off }}$ of $0.880 \pm 0.002$ (Case 5 of Table 7). The difference between the $k_{\text {off }}$ of the slab itself and a large array of cans next to the slab was statistically insignificant at a $95 \%$ confidence level in all but two of the cases evaluated. In these two instances the calculated neutron multiplication factor was lower than for the slab alone. This is due to a portion of the infinite water reflector on the slab being replaced by the array of cans and creating a leakage path. This analysis was performed to determine the safety of removing the requirements for $12 \mathrm{in.} \mathrm{spacing} \mathrm{between} \mathrm{an} \mathrm{array} \mathrm{of} \mathrm{one-gallon} \mathrm{cans} \mathrm{and} \mathrm{other} \mathrm{fisstle}$ material. Similar effects were seen with $U-233$ resulting in a $k_{\text {off }}$ of $0.879 \pm$ 0.002 (Case 7 of Table 7). Sprinkler flooding increased $k_{\text {off }}$ values slightiy, the worst case was for solutions and is discussed in Section 10.3.

The cans were close-packed in triangular pitch in most arrays. Arrays of cans with both centered and offset spherical Pu fuel were evaluated in a rectangular geometry for comparison with the triangular pitched close-packed arrays. In all cases the $k_{\text {off }}$ decreased by greater than three standard deviations $(-6 \%)$. This confirms the assumption that triangular pitched arrays provide the most reactive arrangement (Table 8, Cases 4, 5, 6, and 7).

Normal operating and limiting accident cases were each repeated three times using different neutron starting distributions. These results are itsted in Table 3 of Section 12 and conform to RFP acceptance criteria. 
NMSL: $\quad \frac{90240}{M S 001}$

Engineer: MSOO1.3

Date: $\quad$ December 1991

Page: 64 of 116

\subsection{Plutonium Solution}

For plutonium solutions, a homogeneous mixture composed of 92 vol. $\%$ water and 8 vol.\% polyethylene with a plutonium (95 wt.\% Pu-239, 5 wt.\% $\mathrm{Pu}-240)$ concentration of 1000 grams/liter was assumed. Most samples are less than 1 grams/liter. Plutonium is only soluble in aqueous solutions up to about 600 grams/liter and solutions above 1000 grams/liter are unrealistic. Most samples are suspensions in ofl, in which Pu would be less soluble. If solids are not visible, concentrations are expected to be much less than the assumed 1000 grams/liter. If solids are visible then mass limits will be applied as discussed in Section 10.4. Therefore, the 1000 grams/liter assumption conservatively envelops any credible solution concentrations. The volume limits for the 1000 grams/liter plutonium solution were determined by varying the volume of fuel inside the one-gallon can to generate a range of $k_{\text {eff }}$ values from 0.90 to 1.0 .

The plutonium solution was modeled in spherical geometry (see page 17 of Section 9.2, Section 10.2, and Table 8 of Section 12) and, in most cases, the spheres were offsei in the can as described for the plutonium metal calculations. In some cases the spherical fuel was analyzed centered inside the can for convenience, but limiting cases were compared with results from offset fuel to assure that the more reactive configuration was used. Planar arrays were designed with centered fuel. Conservative concrete reflectors ( 30 $\mathrm{cm}$ on the top and $60 \mathrm{~cm}$ on the bottom) were used for the arrays of containers. Tables 4 and 5 in Section 12 list the KENO-V.a results for the solution cases. A volume of $230 \mathrm{ml}$ per can in a stacked ( $3 \mathrm{high}$ ) infinite array produced a $k_{\text {eff }}$ of $0.949 \pm 0.003$. Limiting and normal operating cases were each repeated three times using different neutron starting distributions. These results are given in Table 6 of Section 12 and conform to RFP acceptance criteria.

Accident cases for plutonium solutions were double-batching, stacking (three high), room flooding, sprinkler flooding, and physical damage. The greater reactivity of soiutions as conimpareut to meta?, did not allow the 20 high stacking models (discussed in the previous section) to be used. The physical size of cans and the instability of stacks makes arrays more than 
NMSL: $\quad 90240$

Engineer: $\mathrm{MSOO1}, 3$

Date: December 1991

Page: 65 of 116

three high unrealistic. Since limits restrict the arrays to planar only, three high stacking is sufficient to analyze an accident scenario.

The first two accidents are addressed in Cases 1 through 7 reported in Tables 4 and 6 of Section 12. The average values for these results are also shown graphically in Figure 3. Flooding and sprinkler accident evaluations are reported in Table 5 . The highest $k_{\text {off }}$ 's resulted when stacked or doublebatched cans were flooded between cans only $(0.744 \pm 0.003$ for stacked cans with a water volume fraction of .75). Flooding increased the $k_{\text {eff }}$ of the normal case (100 $\mathrm{ml}$ per can, cans not stacked) by about $9.6 \%$; however, the value $(0.431 \pm 0.003)$ remained well below 0.90 .

An accident or event in which the containers are breached or crushed, such as a vehicle accident, was also evaluated and a safe transport limit on the number of cans in any shipment was established. It was assumed that the contents of all containers involved in the accident were released and allowed to accumulate into an uncontrolled geometry. The data in Figure 2.10 of Reference 3 indicate that a "safe" subcritical volume limit for individual spheres of homogeneous water-reflected and moderated Pu-239 is about 4 liters. With $100 \mathrm{ml}$ of solution per container, 40 containers are required before the "safe" volume limit could be reached. Since vehicle accidents need not be combined with other accidents a limit of 40 containers for transportation will ensure an adequate margin of safety for these operations (also see Section 8.3, page 38).

The effect of bringing other fissile material into contact with an array of cans was evaluated. A fully water reflected slab of plutonium solution $\left(k_{\text {eff }}=0.891 \pm 0.004\right.$, Ref. $\left.1, p .31\right)$ was aligned next to a $p l$ anar array of double-batched cans (Case 3 of Table 7$)$. The resulting $k_{\text {eff }}(0.889 \pm 0.002)$ indicates that the arrangement has minimal impact on the $k_{\text {eff }}$ of the system. The difference between the $k_{\text {eff }}$ of the slab itself and a large array of cans next to the slab is statistically insignificant at the $95 \%$ confidence level except when $f$ londed and in one other case (see Section 10.2). This system (the slab plus an array of cans) was also analyzed with single-batched, stacked cans and with double-batched, stacked cans to complete the 
NMSL: $\quad \frac{90240}{M S 001}$

Engineer: MSOO1.3

Date:

December 1991

Page: 66 of 116

double-contingency accident scenario. The results, reported in Cases 4 and 6 of Table 7, were similar to Case 3 and indicate that with removal of the spacing requirement the system remains safely subcritical.

The previous conditions were also evaluated combined with sprinkler flooding. The worst case was a stacking/sprinkler (WVF $=0.20$ ) combination for $100 \mathrm{ml} \mathrm{Pu}$ solution per can (Table 7, Case 8). Multiplication factors were slightly higher under flooded conditions because the reflection on the slab that was displaced by the cans in the other models was replaced here with water. However, the calculated $k_{\text {off }}$ of $0.927 \pm 0.004$ demonstrates that even under flooded conditions the array of cans next to the Pu solution slab remains safely subcritical. 
NMSL: $\quad 90240$

Engineer: MSOOL 3

Date: $\quad$ December 1991

Page: 67 of 116

\subsection{Metal Slurries}

The solutions evaluated as discussed in the previous section were 1 imited to a maximum concentration of $1000 \mathrm{~g} / 1$. Under operating conditions the actual concentration may not be known; therefore, higher concentrations need to be considered. Since plutonium and uranium are not soluble at these high concentrations the material has been labeled a slurry (solution system containing undissolved solids). This material was modeled as arrays of cans containing a constant mass of 200 grams $\mathrm{Pu}$ per can with the solids displacing solution (92 vol.\% water, 8 vol.\% polyethylene) as the density increased.

Results indicated that the k-effective remains essentially unchanged with increasing density higher than about $5000 \mathrm{~g} / 1$ (See Table 11 and Figure 5). slurry accident cases were evaluated using $5000 \mathrm{~g} / 1$ concentrations for uranium and plutonium. For the normal and typical operating conditions evaluated slurries were less reactive than metals, and for the spacing evaluation the results were statistically identical. However, for some accident cases, the slurries had higher calculated $k_{\text {eff }}$ values. This is presumably because the greater volume of slurry ( $P u$ me al density is $19.84 \mathrm{~g} / \mathrm{cc}$, slurry is $5 \mathrm{~g} / \mathrm{cc}$ ) is more sensitive to some of the accident conditions. The slurries were shown to be safely subcritical for all required accident scenarios when the same mass limit $(50 \mathrm{~g})$ that was established for metals is applied. Mass, not volume limits must be applied if there are undissolved solids in a solution system of unknown concentration.

Neutron multiplication factors greater than 1.0 were calculated when the cans containing $1 / 2$ inch lead shielding were modeled with 100 grams of slurry. As with the metal cases this is considered overly conservative since the cans are stacked 20 high. Slurries were shown safe in lead shielded cans when doubled batched and stacked only 3 high (Case 19 of Table 2, and Case 18 of Table 9). This is adequate to meet double contingency requirements as explained previously. 
NMSL: $\quad 90240$

Engineer: "MSO01.3

Date: December 1991

Page: 68 of 116

\section{SCALED DRAWINGS}

See Figure 1, page 61. 
NMSL: $\quad 90240$

Engineer: MSOOI.3

Date: December 1991

Page: 69 of 116

\section{SUMARY OF CALCULATION RESULTS}

TABLE 2. SUMMARY OF KENO-V.A RESULTS FOR PU METAL SHOWING THE EFFECTS OF ALL DEGREES OF MODERATION

\begin{tabular}{|c|c|c|}
\hline Case ID & Descriotion & $k \pm \sigma$ \\
\hline 1 & $\begin{array}{l}100 \text { grams Pu metal per can, cans stacked } \\
20 \text { high, fuel offset axtally and radially } \\
\text { in can, } 1 \text { ft. concrete reflector above cans, } \\
2 \text { ft. concrete reflector below cans, the } \\
\text { remaining volume inside and between cans is } \\
\text { vold. }\end{array}$ & $0.76716 \pm 0.00394$ \\
\hline 2 & $\begin{array}{l}\text { Same as Case } 1 \text { except moderated/reflected } \\
\text { inside and between cans with polyethylene } \\
\text { with a volume fraction of } 0.01 \text {. }\end{array}$ & $0.74639 \pm 0.00319$ \\
\hline 3 & $\begin{array}{l}\text { Same as Case } 1 \text { except moderated/reflected } \\
\text { inside and between cans with polyethylene } \\
\text { with a volume fraction of } 0.05 \text {. }\end{array}$ & $0.61082 \pm 0.00293$ \\
\hline 4 & $\begin{array}{l}\text { Same as Case } 1 \text { except moderated/reflected } \\
\text { inside and between cans with polyethylene } \\
\text { with a volume fraction of } 0.07 \text {. }\end{array}$ & $0.56717 \pm 0.00287$ \\
\hline 5 & $\begin{array}{l}\text { Same as Case } 1 \text { except moderated/reflected } \\
\text { inside and between cans with polyethylene } \\
\text { with a volume fraction of } 0.10 \text {. }\end{array}$ & $0.50825 \pm 0.00295$ \\
\hline 6 & $\begin{array}{l}\text { Same as Case } 1 \text { except moderated/reflected } \\
\text { inside and between cans with polyethylene } \\
\text { with a volume fraction of } 0.25 \text {. }\end{array}$ & $0.39061 \pm 0.00261$ \\
\hline 7 & $\begin{array}{l}\text { Same as Case } 1 \text { except moderated/reflected } \\
\text { inside and between cans with polyeinylene } \\
\text { with a volume fraction of } 0.50 \text {. }\end{array}$ & $0.38303 \pm 0.00261$ \\
\hline 8 & $\begin{array}{l}\text { Same as Case } 1 \text { except moderated/reflected } \\
\text { inside and between cans with polyethylene } \\
\text { with a volume fraction of } 0.75 \text {. }\end{array}$ & $0.40956 \pm 0.00300$ \\
\hline 9 & $\begin{array}{l}\text { Same as Case } 1 \text { except moderated/reflected } \\
\text { inside and between cans with polyethylene } \\
\text { with a volume fraction of } 1.00 \text {. }\end{array}$ & $0.43939 \pm 0.00256$ \\
\hline
\end{tabular}


NMSL: $\quad 90240$

Engineer: $\mathrm{MSOO1.3}$

Date: December 1991

Page: 70 of 116

TABLE 2. CONTINUED

Case ID

10

11

12

13

14

15

16

17

18

19
Description

Same as Case 1 except moderated/reflected inside and between cans with water with a volume fraction of 1.0 (flooding).

Same as Case 1 except moderated/reflected inside and between cans with water with a volume fraction of 0.5 (sprinkler accident).

Same as Case 1 except moderated/reflected inside and between cans with water with a volume fraction of 0.1 (sprinkler accident).

Same as Case 1 except moderated/reflected between cans with water with a volume fraction of 0.1 (sprinkler accident).

4 Same as Case 1 except moderator is polyethylene with a volume fraction of 1.0 between cans only.

5 Same as Case 1 except moderator is polyethylene with a volume fraction of 1.00 inside cans only.

6. Normal case, 50 grams Pu per can, stacked 20 high, the remaining volume inside and between cans is void.

17100 grams $\mathrm{Pu}$ per can, stacked $3 \mathrm{high}$, cans contain $1 / 2$ inch lead shielding

100 grams of Pu slurry $(5000 \mathrm{~g} / 1,20 \mathrm{ml}) \mathrm{Pu}$ metal displaces $92 \%$ water $8 \%$ poly, stacked 20 high

100 grams of Pu slurry $(5000 \mathrm{~g} / 1,20 \mathrm{ml}) \mathrm{Pu}$ metal displaces $92 \%$ water $8 \%$ poly, stacked 3 high, cans contain $1 / 2$ inch lead shielding $k \pm \sigma$

$0.41715 \pm 0.00272$

$0.37717 \pm 0.00265$

$0.54380 \pm 0.00286$

$0.74989 \pm 0.00398$

$0.52368 \pm 0.00284$

$0.42162 \pm 0.00247$

$0.53083 \pm 0.00335$

$0.36340 \pm 0.00235$

$0.88820 \pm 0.00302$

$0.37881 \pm 0.00246$ 


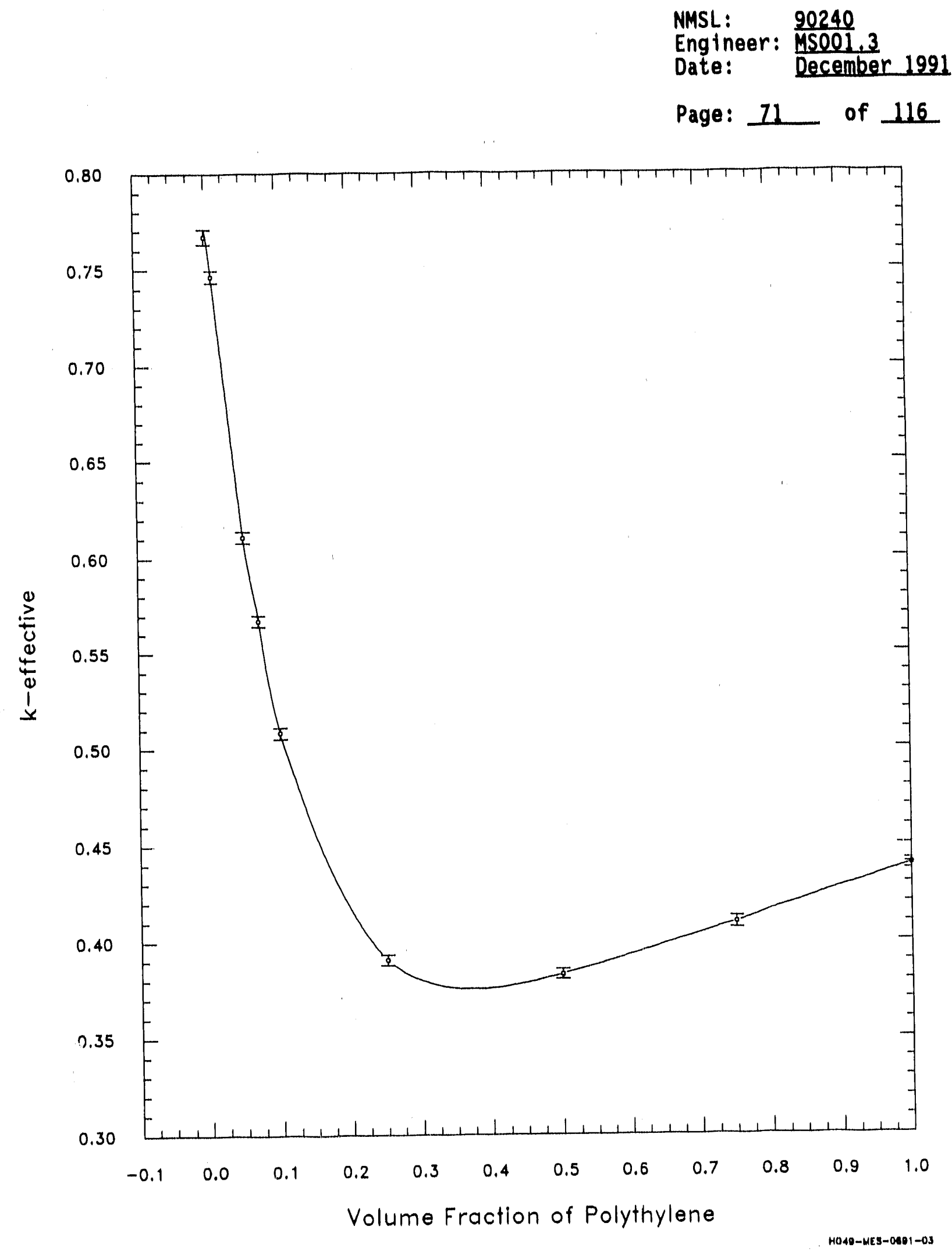

Figure 2. Effects of all degrees of moderation Pu metal cases. 
NMSL:
Engineer: $\frac{90240}{\text { DSO01.3 }}$
Date:

Page: 72 of 116

TABLE 3. SUMARY OF KENO-V.A RESULTS FOR PU METAL

\begin{tabular}{cccccc}
\hline $\mathrm{ID}^{a}$ & $\frac{k_{1} \pm \sigma^{\mathrm{a}}}{1}$ & $0.76716 \pm 0.00394$ & $\frac{k_{2} \pm \sigma}{0.76670 \pm 0.00364}$ & $0.76574 \pm 0.00367$ & $0.76651 \pm 0.00216$ \\
$1 \mathrm{a}^{\mathrm{b}}$ & $0.76494 \pm 0.00423$ & $0.76697 \pm 0.00380$ & $0.76523 \pm 0.00383$ & $0.76577 \pm 0.00227$ \\
10 & $0.41715 \pm 0.00272$ & $0.41573 \pm 0.06278$ & $0.41842 \pm 0.00334$ & $0.41695 \pm 0.00168$ \\
13 & $0.74989 \pm 0.00389$ & $0.76110 \pm 0.00398$ & $0.75893 \pm 0.00364$ & $0.75862 \pm 0.00251$ \\
$13 \mathrm{a}^{\mathrm{b}}$ & $0.75597 \pm 0.00390$ & $0.76043 \pm 0.00432$ & $0.74940 \pm 0.00441$ & $0.75539 \pm 0.00242$ \\
16 & $0.53083 \pm 0.00335$ & $0.53349 \pm 0.00332$ & $0.53664 \pm 0.00347$ & $0.53358 \pm 0.00195$ \\
18 & $0.8820 \pm 0.00302$ & $0.88620 \pm 0.00278$ & $0.88721 \pm 0.00325$ & $0.88714 \pm 0.00173$
\end{tabular}

a. From Table 2

b. Cases la and 13a were evaluated with the alternate unit cell shown in Figure 1 
NMSL: $\quad 90240$

Engineer: $\mathrm{MSOOL}, 3$

Date:

December 1991

Page: 73 of 116

TABLE 4. SUMMARY OF KENO-V.A RESULTS FOR PU SOLUTION SHOWING THE EFFECTS OF VARIATION IN THE VOLUME OF FUEL

\begin{tabular}{|c|c|c|}
\hline Case ID & Descrietion & $k \pm \sigma$ \\
\hline 1 & $\begin{array}{l}200 \mathrm{ml} \text { Pu solution }(1000 \mathrm{~g} / 1 \text { in } 92 \text { vol. } \\
\text { water, } 8 \text { vol. } \% \text { polyethylene) per can, cans } \\
\text { stacked } 3 \text { high, fuel offset axtally and } \\
\text { radially in can, } 30 \mathrm{~cm} \text { concrete reflector } \\
\text { above cans, } 60 \mathrm{~cm} \text { concrete reflector below } \\
\text { cans. }\end{array}$ & $0.90225 \pm 0.00356$ \\
\hline 2 & Same as Case 1 except fuel volume is $225 \mathrm{ml}$. & $0.93939 \pm 0.00359$ \\
\hline 3 & Same as Case 1 except fuel volume is $230 \mathrm{ml}$. & $0.94857 \pm 0.00320$ \\
\hline 4 & Same as Case 1 except fuel volume is $250 \mathrm{ml}$. & $0.98180 \pm 0.00327$ \\
\hline 5 & Same as Case 1 except fuel volume is $270 \mathrm{ml}$. & $1.00097 \pm 0.00329$ \\
\hline 6 & Same as Case 1 except fuel volume is $275 \mathrm{ml}$. & $1.00572 \pm 0.00336$ \\
\hline 7 & Same as Case 1 except fuel volume is $300 \mathrm{ml}$. & $1.04231 \pm 0.00349$ \\
\hline 8 & $\begin{array}{l}\text { Normal case, } 100 \mathrm{ml} \text { fuel volume infinite } \\
\text { planar array, not stacked, fuel centered } \\
\text { in can. }\end{array}$ & $0.39345 \pm 0.00298$ \\
\hline
\end{tabular}


NMSL: $\quad 90240$

Engineer: $\mathrm{MSOOL}_{2} 3$

Date: December 1991

Page: 14 of 116

TABLE 5. SUMMARY OF KENO-V.A RESULTS FOR PU SOLUTION SHOWING THE EFFECTS OF ALL DEGREES OF MODERATION

\begin{tabular}{|c|c|c|}
\hline Case 10 & Descriotion & $k \pm \sigma$ \\
\hline 1 & $\begin{array}{l}200 \mathrm{ml} \text { Pu solution ( } 1000 \mathrm{~g} / 1 \text { in } 92 \text { vol.\% } \\
\text { water, } 8 \text { vol.\% polyethylene) per can, planar, } \\
30 \mathrm{~cm} \text { concrete above cans, } 60 \mathrm{~cm} \text { concrete } \\
\text { below cans. Flooded between cans only with } \\
\text { water volume fraction }=1,00 \text {. }\end{array}$ & $0.62225 \pm 0.003) 2$ \\
\hline 2 & Same as Case 1 except WVF $=0.75$ & $0.60386 \pm 0.00342$ \\
\hline 3 & Same as Case 1 except WVF $=0.50$. & $0.59874 \pm 0.00293$ \\
\hline 4 & Same as Case 1 except WVF $=0.25$. & $0.58709 \pm 0.00322$ \\
\hline 5 & Same as Case 1 except WVF $=0.10$ & $0.57580 \pm 0.00313$ \\
\hline 6 & Same as Case 1 except WVF $=0.0$ & $0.57341 \pm 0.00312$ \\
\hline 7 & $\begin{array}{l}100 \mathrm{ml} \text { fuel volume, fuel offset in can, } \\
\text { cans stacked } 3 \mathrm{high} \text {, flooded between cans } \\
\text { only with a water volume fraction }=1.00 \text {. }\end{array}$ & $0.73881 \pm 0.00315$ \\
\hline 8 & Same as Case 7 except WVF $=0.75$. & $0.74358 \pm 0.00322$ \\
\hline 9 & Same as Case 7 except WVF $=0.50$ & $0.73065 \pm 0.00306$ \\
\hline 10 & Same as Case 7 except WVF $=0.25$. & $0.71046 \pm 0.00312$ \\
\hline 11 & Same as Case 7 except WVF $=0.10$ & $0.69074 \pm 0.00316$ \\
\hline 12 & Same as Case 7 except WVF $=0.0$ & $0.66872 \pm 0.00309$ \\
\hline 13 & $\begin{array}{l}\text { Normal case, } 100 \mathrm{ml} \text { fuel volume, infinite } \\
\text { planar array }\left(k_{d}=0.39345 \pm 0.00298\right. \\
\left.k_{2}=0.38931 \pm 0.00289, k_{3}=0.39186 \pm 0.00280\right)\end{array}$ & $0.39151 \pm 0.00166^{\circ}$ \\
\hline 14 & $\begin{array}{l}\text { Same as Case } 13 \text { except flooded } \\
\text { between cans only, WVF }=1.00 \text {. }\end{array}$ & $0.43140 \pm 0.00265$ \\
\hline
\end{tabular}


NMSL: $\quad 90240$

Engineer: MSOOL,3

Date: December 1991

Page: 15 of 116

TABLE 5. continued

\begin{tabular}{lll}
\hline 15 & $\begin{array}{l}\text { Same as Case 13 except flooded } \\
\text { inside cans only, WVF }=1.00 .\end{array}$ & $0.33474 \pm 0.00258$ \\
16 & $\begin{array}{l}\text { Same as Case } 13 \text { except flooded } \\
\text { everywhere, WVF }=1.00\end{array}$ & $0.32486 \pm 0.00260$ \\
& & \\
17 & $\begin{array}{l}200 \mathrm{ml} P u \text { solution }(1000 \mathrm{~g} / 1) \text { per can } \\
\text { stacked } 3 \text { high, } 1 / 2 \text { inch lead shielding } \\
\left(k_{1}=0.92499 \pm 0.00307, k_{2}=0.92654 \pm 0.00306,\right.\end{array}$ & $0.92630 \pm 0.00185^{\circ}$ \\
& $\left.k_{3}=0.92772 \pm 0.00354\right)$.
\end{tabular}

a. Weighted average 
NMSL: $\quad \frac{90240}{M S 001}$

Engineer: MSO01,3

Date: December 1091

Page: 76 of 116

TABLE 6. SUMMARY OF KENO-V.A RESULTS FOR PLUTONIUM SOLUTION

\begin{tabular}{cccccc}
\hline ID & $k_{1} \pm \sigma^{*}$ & $k_{2} \pm \sigma$ & $k_{3} \pm \sigma$ & $k \pm \sigma$ \\
1 & $0.90225 \pm 0.00356$ & $0.90119 \pm 0.00363$ & $0.90423 \pm 0.00355$ & $0.90258 \pm 0.00207$ \\
2 & $0.93939 \pm 0.00359$ & $0.94289 \pm 0.00348$ & $0.94216 \pm 0.00363$ & $0.94150 \pm 0.00206$ \\
3 & $0.94857 \pm 0.00320$ & $0.95523 \pm 0.00337$ & $0.95814 \pm 0.00389$ & $0.95341 \pm 0.00199$ \\
4 & $0.98180 \pm 0.00327$ & $0.97851 \pm 0.00324$ & $0.97584 \pm 0.00315$ & $0.97864 \pm 0.00186$ \\
5 & $1.00097 \pm 0.00329$ & $0.99956 \pm 0.00369$ & $1.00738 \pm 0.00364$ & $1.00255 \pm 0.00204$ \\
6 & $1.00572 \pm 0.00336$ & $1.00919 \pm 0.00319$ & $1.00817 \pm 0.00304$ & $1.00777 \pm 0.00184$ \\
8 & $0.39345 \pm 0.00298$ & $0.38931 \pm 0.00289$ & $0.39186 \pm 0.00280$ & $0.39151 \pm 0.00167$
\end{tabular}

a. From Table 4 


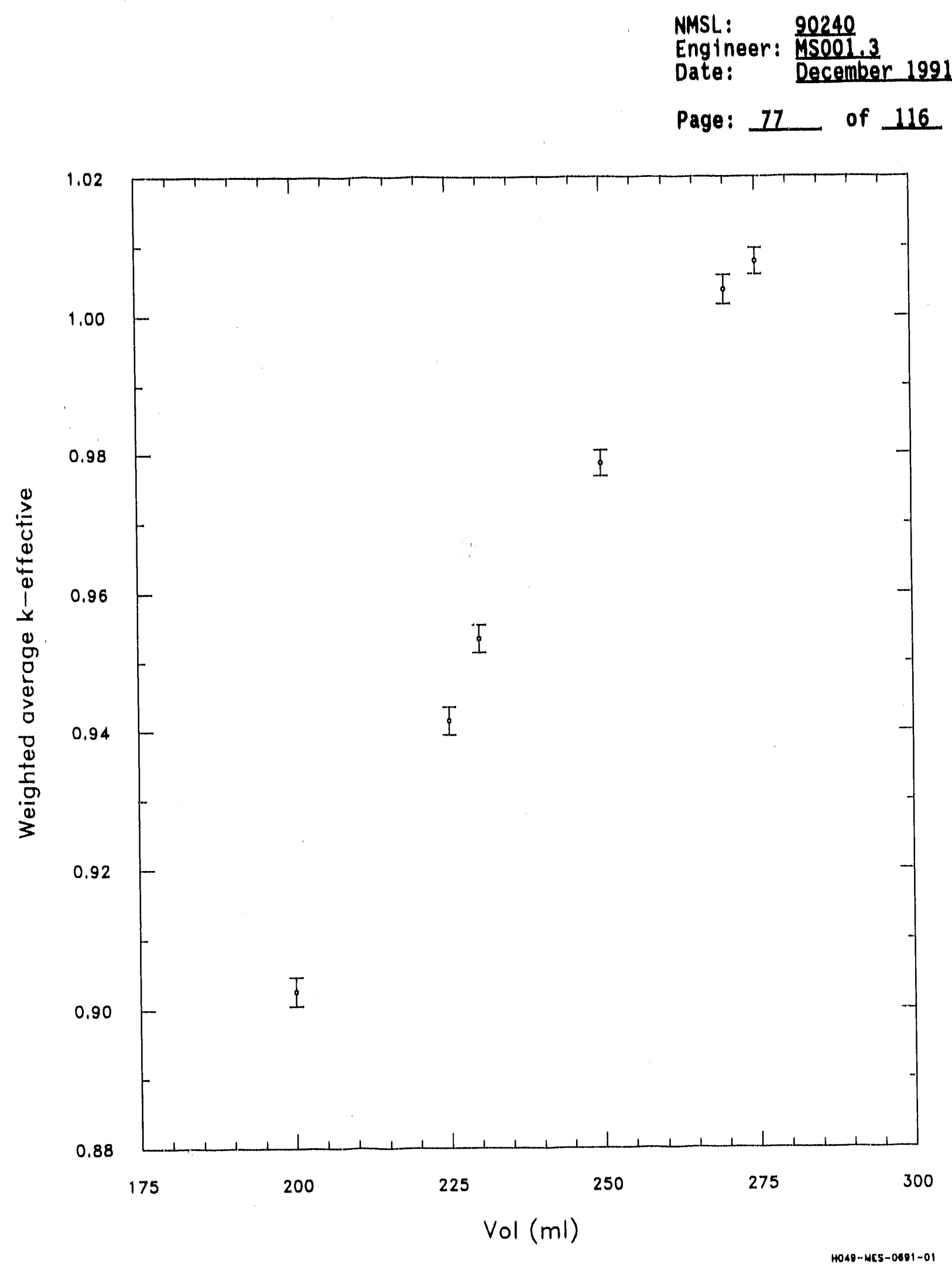

Figure 3. Volume of Pu solution vs. k-effective, double batched 1 gallon cans, stacked 3 high (offset spherical fuel). 
NMSL: $\quad 90240$

Engineer: $\mathrm{MSOO1}, 3$

Date: December 1991

Page: 78 of 116

TABLE 7. SUMMARY OF KENO-V.A RESULTS SHOWING THE EFFECTS OF INTERACTION WITH SLAB OF PLUTONIUM SOLUTION HAVING A K KEF OF 0.90

(REFERENCE 1, SECTION 5.2.4)

Case ID

1

2

3

3

4

5

6

7

7 Same as Case 5 except cans contain $100 \mathrm{~g}$ of U-233 $\left(k_{1}=0.88536 \pm 0.00403, k_{2}=0.87722 \pm\right.$ $\left.0.00337, k_{3}=0.87397 \pm 0.00407\right)^{2}$.

8 Same as Case 4 except sprinkler flooded at

0.2 WVF between cans.

Description

Large array $(25 \times 50 \times 1)$ of cans against

Pu solution slab; 100 grams Pu metal per can

$\left(k_{1}=0.88934 \pm 0.00393, k_{2}=0.89408 \pm 0.00378\right.$, $\left.k_{3}=0.88495 \pm 0.00415\right)$.

Same as Case 1 except cans contain 50 grams of Pu metal and are stacked 3 high

$\left(k_{1}=0.88563 \pm 0.00410, k_{2}=0.88720 \pm 0.00382\right.$, $\left.k_{3}=0.88002 \pm 0.00392\right)$.

Same as Case 1 except cans contain $200 \mathrm{ml}$ of $\mathrm{Pu}$ Solution $(1000 \mathrm{~g} / \mathrm{l})\left(k_{1}=0.88861 \pm 0.00421\right.$. $\left.k_{2}=0.88649 \pm 0.00413, k_{3}=0.89351 \pm 0.00423\right)$.

Same as Case 1 except cans contain $100 \mathrm{ml}$ of $\mathrm{Pu}$ solution $(1000 \mathrm{~g} / \mathrm{L})$ and cans are stacked $3 \mathrm{high}\left(k_{1}=0.88019 \pm 0.00382, k_{2}=0.87909 \pm\right.$ $\left.0.00383, k_{3}=0.88135 \pm 0.00356\right)$.

Same as Case 1 except cans contain $100 \mathrm{~g}$ of Pu metal and cans are stacked

3 high $\left(k_{1}=0.87947 \pm 0.00387, k_{2}=0.88295 \pm\right.$ $\left.0.00408, k_{3}=0.87772 \pm 0.00403\right)$.

Same as Case 1 except cans contain $200 \mathrm{ml}$ of $\mathrm{Pu}$ solution $(1000 \mathrm{~g} / \mathrm{L})$ and cans are stacked 3 high $\left(k_{2}=0.89063 \pm 0.00381, k_{2}=0.88298 \pm\right.$ $\left.0.00363, k_{3}=0.87957 \pm 0.00386\right)$.

\author{
$k \pm \sigma$ \\ $0.88974 \pm 0.00228^{\circ}$ \\ $0.88430 \pm 0.00228^{\circ}$ \\ $0.88949 \pm 0.00242^{n}$ \\ $0.88027 \pm 0.00215^{a}$ \\ $0.88000 \pm 0.00230^{\circ}$ \\ $0.88439 \pm 0.00217^{\circ}$ \\ $0.87867 \pm 0.00218$ \\ $0.92651 \pm 0.00392$
}

a. Weighted average 
NWSL: $\quad 90240$

Engineer: $\mathrm{MSO01.3}$

Date: December 1991

Page: 79 of 116

TABLE 8. SUMMARY OF KENO-V.A RESULTS FOR ALTERNATE GEOMETRIES

\begin{tabular}{|c|c|c|}
\hline Case 10 & Description & $k \pm \sigma$ \\
\hline 1 & $\begin{array}{l}\text { "Pile" of } 60100 \mathrm{~g} \text { spheres, close-packed } \\
\text { fully water reflected (vehicle accident) } \\
\left(k_{1}=0.92801 \pm 0.00409, k_{1}=0.92929 \pm 0.00410,\right. \\
\left.k_{3}=0.92768 \pm 0.00378 .\right)\end{array}$ & $0.92829 \pm 0.00230^{\circ}$ \\
\hline 2 & $\begin{array}{l}12550 \mathrm{~J} \text { spheres, rectangular pitch, } \\
\text { close packed }\left(k_{d}=0.90321 \pm 0.00439\right. \\
\left.k_{2}=0.90950 \pm 0.00397, k_{3}=0.90786 \pm 0.00435\right)\end{array}$ & $0.90704 \pm 0.00244^{\circ}$ \\
\hline 3 & $\begin{array}{l}12550 \mathrm{~g} \text { sphere, rectangular pitch, } \\
\text { separation } 1 \mathrm{~cm}\end{array}$ & $0.84565 \pm 0.00381$ \\
\hline 4 & $\begin{array}{l}\text { An infinite rectangular array of one- } \\
\text { gallon cans, stacked } 20 \mathrm{high}, 100 \mathrm{~g} \text { per } \\
\text { can, offset fuel }\end{array}$ & $0.72974 \pm 0.00345$ \\
\hline 5 & $\begin{array}{l}\text { Same as Case } 4 \text { with triangular pitch } \\
\text { (see Case } 1 \text { of Table } 2 \text { ) }\end{array}$ & $0.76716 \pm 0.00394$ \\
\hline 6 & $\begin{array}{l}\text { An infinite planar array with rectangular } \\
\text { pitch of one-gallon cans, } 100 \mathrm{~g} \text { per can, } \\
\text { centered fuel }\end{array}$ & $0.70696 \pm 0.00297$ \\
\hline 7 & Same as Case 6 with triangular pitch & $0.75232 \pm 0.00374$ \\
\hline 8 & $\begin{array}{l}\text { Cylindrical fuel, Pu, } 100 \mathrm{~g} / \text { can. Same as } \\
\text { Case } 1, \text { Table } 2 \text { except for cylindrical fuel } \\
\text { geometry }\left(k_{2}=0.77756 \pm 0.00370, k_{2}=0.77122\right. \\
\left. \pm 0.00362, k_{3}=0.77038 \pm 0.00409\right) .\end{array}$ & $0.77319 \pm 0.00370^{\circ}$ \\
\hline 9 & $\begin{array}{l}\text { Cylindrical fuel, Pu solution, } 200 \mathrm{ml} / \mathrm{can} \text {. } \\
\text { Same as Case } 1, \text { Table } 4 \text { except for cylindrical } \\
\text { fuel geometry }\left(k_{d}=0.91002 \pm 0.00350, k_{2}=0.90679\right. \\
\left. \pm 0.00350, k_{3}=0.91477 \pm 0.00368\right)\end{array}$ & $0.91039 \pm 0.00205^{\circ}$ \\
\hline 10 & $\begin{array}{l}\text { Cylindrical fue1, } U-233,100 \mathrm{~g} / \mathrm{can} \text {. Same as } \\
\text { Case } 14 \text {, Table } 9 \text { except for cyl indrical fuel } \\
\text { geometry (flooded between cans with. } 05 \text { water } \\
\text { volume fraction. })\left(k_{1}=0.82619 \pm 0.00364, k_{2}=0.824\right. \\
\left. \pm 0.00365, k_{3}=0.83050 \pm 0.00380\right) .\end{array}$ & $0.82690 \pm 0.00213^{\circ}$ \\
\hline
\end{tabular}

a. Weighted average 
NMSL: : $\quad \frac{90240}{M S O 01}$

Engineer: MSO01.3

Date: December 1991

Page: 80 of 116

TABLE 9. SUMMARY OF KENO-V.A RESULTS FOR U-233 METAL SHOWING THE EFFECTS OF ALL DEGREES OF MODERATION

\begin{tabular}{|c|c|c|}
\hline Case ID & Descriotion & $k \pm \sigma$ \\
\hline 1 & $\begin{array}{l}100 \text { grams } U-233 \text { metal per can, cans stacked } \\
20 \text { high, fuel offset axially and radially } \\
\text { in can, } 1 \text { ft. concrete reflector above cans, } \\
2 \mathrm{ft} \text {. concrete reflector below cans, the } \\
\text { remaining volume inside and between cans is } \\
\text { void. }\end{array}$ & $0.79622 \pm 0.00408$ \\
\hline 2 & $\begin{array}{l}\text { Same as Case } 1 \text { except moderated/reflected } \\
\text { inside and between cans with polyethylene } \\
\text { with a volume fraction of } 0.01 \text {. }\end{array}$ & $0.80980 \pm 0.00352$ \\
\hline 3 & $\begin{array}{l}\text { Same as Case } 1 \text { except moderated/reflected } \\
\text { inside and between cans with priyethylene } \\
\text { with a volume fraction of } 0.1, \text {. }\end{array}$ & $0.65447 \pm 0.00306$ \\
\hline 4 & $\begin{array}{l}\text { Same as Case } 1 \text { except moderated/reflected } \\
\text { inside and between cans with polyethylene } \\
\text { with a volume fraction of } 0.10 \text {. }\end{array}$ & $0.53258 \pm 0.00274$ \\
\hline 5 & $\begin{array}{l}\text { Same as Case } 1 \text { except moderated/reflected } \\
\text { ifistde and between cans with polyethylene } \\
\text { with a volume fraction of } 0.25 \text {. }\end{array}$ & $0.37072 \pm 0.00257$ \\
\hline 6 & $\begin{array}{l}\text { Same as Case } 1 \text { except moderated/reflected } \\
\text { inside and between cans with polyethylene } \\
\text { with a volume fraction of } 1.00 \text {. }\end{array}$ & $0.44877 \pm 0.00289$ \\
\hline 7 & $\begin{array}{l}\text { Same as Case } 1 \text { except moderator is } \\
\text { polyethylene with a volume fraction of } \\
1.0 \text { between cans only. }\end{array}$ & $0.55195 \pm 0.00291$ \\
\hline 8 & $\begin{array}{l}\text { Same as Case } 1 \text { except moderator is } \\
\text { polyethylene with a volume fraction of } \\
1.00 \text { inside cans only. }\end{array}$ & $0.42662 \pm 0.00274$ \\
\hline 9 & $\begin{array}{l}\text { Same as Case } 1 \text { except moderated/reflected } \\
\text { inside and between cans with water } \\
\text { with a volume fraction of } 1.0 \text { (flooding). }\end{array}$ & $0.42510 \pm 0.00282$ \\
\hline 10 & $\begin{array}{l}\text { Same as Case } 1 \text { except moderated/reflected } \\
\text { between cans only with water } \\
\text { with a volume fraction of } 1.0 \text { (flooding). }\end{array}$ & $0.58126 \pm 0.00303$ \\
\hline
\end{tabular}


NMSL: $\quad 90240$

Engineer: $\mathrm{MSOON} .3$

Date:

December 1991

Page: 81 of 116

TABLE 9. CONTINUED

Case ID

Description

$k \pm \sigma$

11 Same as Case 1 except moderated/reflected

$0.57172 \pm 0.00280$ inside and between cans with water with a volume fraction of 0.1 (sprinkler accident).

12 Same as Case 1 except moderated/reflected between cans only with water with a volume fraction of 0.1 (sprinkler accident).

13 Same as Case 1 except moderated/reflected between cans only with water with a volume fraction of 0.07 (sprinkler accident).

14 Same as Case 1 except moderated/reflected between cans only with water with a volume fraction of 0.05 (sprinkler accident $).\left(k_{1}=0.82506 \pm 0.00336 \quad k_{2}=0.82256\right.$ $\pm 0.00409, k_{3}=0.83204 \pm 0.00358$ )

$0.82445 \pm 0.00338$

$0.82676 \pm 0.00341$

$0.82681 \pm 0.00210^{\circ}$

Same as Case 1 except moderated/reflected between cans only with water with a volume fraction of 0.02 (sprinkler accident).

16 Normal case, 50 grams U-233 per can, stacked $20 \mathrm{high}$, the remaining volume inside and between cans is void $\left(k_{1}=0.57202 \pm 0.00373\right.$, $\left.k_{2}=0.57595 \pm 0.00361, k_{3}=0.56682 \pm 0.00367\right)$.

$17100 \mathrm{~g} \mathrm{U}-233$ metal slurry $(5000 \mathrm{~g} / 1,20 \mathrm{ml})$ $U$ metal displaces $92 \%$ water $8 \%$ polyethylene stacked 20 high

$0.82138 \pm 0.00352$

Same as Case 17 except cans contain $1 / 2$ inch lead shielding and are stacked 3 high

$0.57164 \pm 0.00212^{a}$

$0.70023 \pm 0.00336$

$0.26011 \pm 0.00215$

18

a. Heighted average 
NMSL: $\quad 90240$

Engineer: $\mathrm{MSOOT}, 3$

Date:

December 1991

Page: 82 of 116

TABLE 10. SUMMARY OF KENO-V.A RESULTS FOR U-233 METAL SHOWING THE EFFECTS OF STACKING CANS CONTAINING $1 / 2$ INCH LEAD SHIELDING

\begin{tabular}{|c|c|c|}
\hline Case ID & Descrintion & $k \pm \sigma$ \\
\hline 1 & $\begin{array}{l}100 \mathrm{~g} \mathrm{U}-233 \text { metal per can, stacked } 20 \text { high, } \\
\text { cans contain } 1 / 2 \text { inch lead shielding }\end{array}$ & $1.14697 \pm 0.00476$ \\
\hline 2 & $\begin{array}{l}100 \mathrm{~g} \mathrm{U} \text { U-233 metal per can, stacked } 15 \text { high, } \\
\text { cans contain } 1 / 2 \text { inch lead shielding }\end{array}$ & $0.92770 \pm 0.0445$ \\
\hline 3 & $\begin{array}{l}100 \mathrm{~g} \mathrm{U}-233 \text { metal per can, stacked } 10 \text { high, } \\
\text { cans contain } 1 / 2 \text { inch lead shielding }\end{array}$ & $0.67499 \pm 0.00299$ \\
\hline 4 & $\begin{array}{l}100 \mathrm{~g} \mathrm{U}-233 \text { metal per can, stacked } 5 \text { high, } \\
\text { cans contain } 1 / 2 \text { inch lead shielding }\end{array}$ & $0.45901 \pm 0.00266$ \\
\hline 5 & $\begin{array}{l}100 \mathrm{~g} \mathrm{U}-233 \text { metal per can, stacked } 3 \text { high, } \\
\text { cans contain } 1 / 2 \text { inch lead shielding }\end{array}$ & $0.37450 \pm 0.00260$ \\
\hline
\end{tabular}


NMSL: $\quad 90240$

Engineer: $\mathrm{MSOOD} .3$

Date: $\quad$ December 1991

Page: 83 of 116

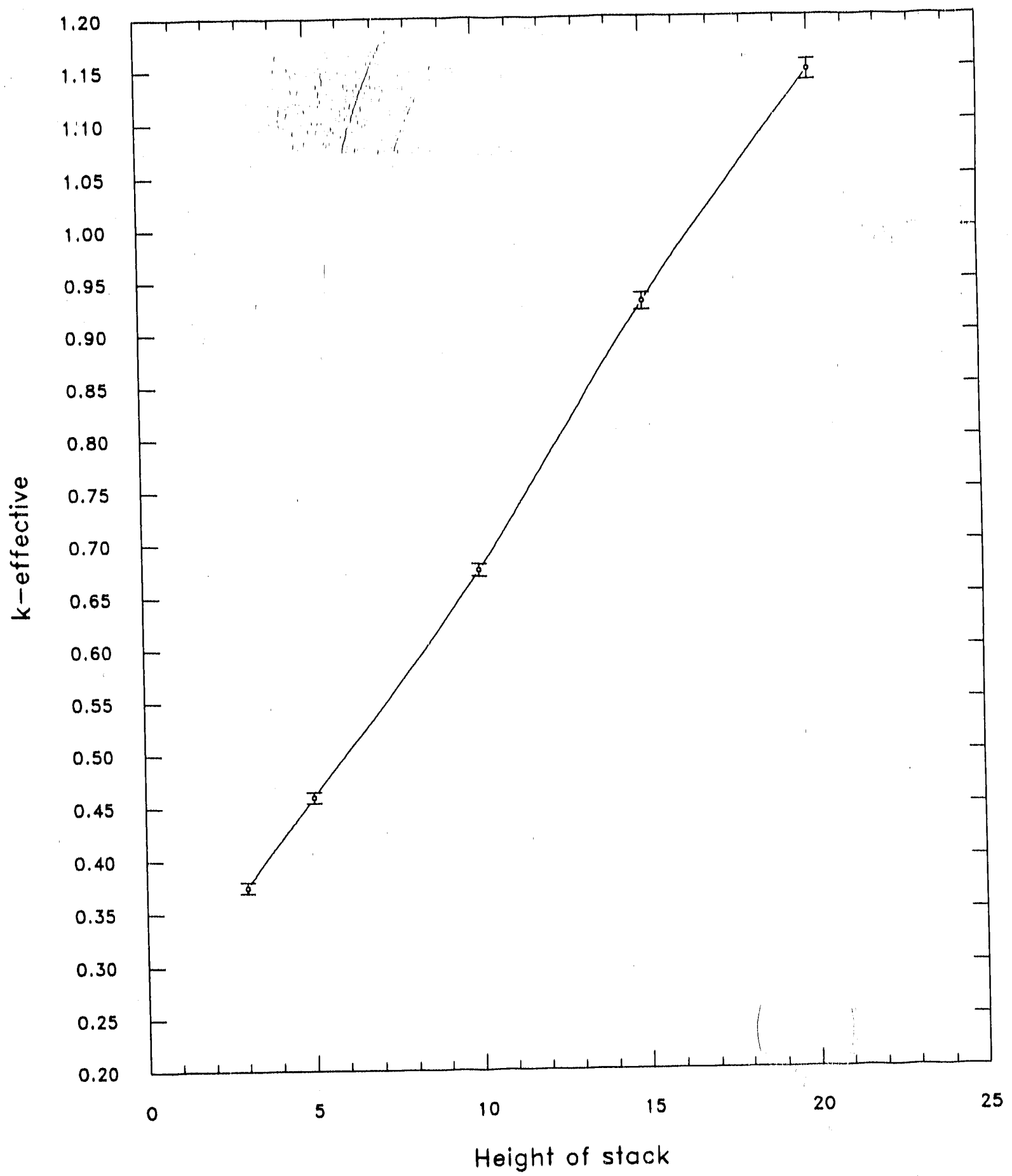

Figure 4. Effects of stacking arrays of cans with $1 / 2$ inch lead shielding, 100 grams $U-233$ per can. 
NMSL: $\quad 90240$

Engineer: MSOOL. 3

Date:

December 1991

Page: 84 of 116

TABLE 11. SUMMARY OF KENO-V.A RESULTS FOR PU METAL SHOWING THE EFFECT OF INCREASING DENSITY

Case 10

Descriotion

$k \pm \sigma$

$1200 \mathrm{~g}$ Pu slurry (92 vol.\% water, 8 vol.\% polyethylene) per can, $200 \mathrm{ml}$, density $1 \mathrm{~g} / \mathrm{ml}$ stacked $3 \mathrm{high}$

2 Same as Case 1 , except $150 \mathrm{ml}$, density 1.3 $\mathrm{g} / \mathrm{m} 1$

$0.82158 \pm 0.00342$

Same as Case 1, except $100 \mathrm{ml}$, density 2.0

$0.72848 \pm 0.00308$ $\mathrm{g} / \mathrm{m} \mathbf{1}$

4 Same as Case 1, except $66.7 \mathrm{ml}$, density $3.0 \quad 0.65338 \pm 0.00324$ $\mathrm{g} / \mathrm{m} \mathbf{1}$

5 Same as Case 1 , except $50 \mathrm{ml}$, density 4.0 $\mathrm{g} / \mathrm{ml}$

$0.61673 \pm 0.00298$

Same as Calse 1, except $40 \mathrm{ml}$, density 5.0 $g / m 1$

$0.58420 \pm 0.00304$

Same as Case 1 , except $33.3 \mathrm{ml}$, density $6.0 \quad 0.56429 \pm 0.00274$ $\mathrm{g} / \mathrm{ml}$

8 Same as Case 1, except $28.6 \mathrm{ml}$, density 7.0 $g / m 1$

$0.54785 \pm 0.00283$

Same as Case 1, except $25 \mathrm{ml}$, density 8.0 $\mathrm{g} / \mathrm{m} \mathrm{l}$

$0.54413 \pm 0.00288$

10 Same as Case 1, except $22.2 \mathrm{ml}$, density 9.0 $\mathrm{g} / \mathrm{ml}$

$0.54474 \pm 0.00290$

11 Same as Case 1 , except $20 \mathrm{ml}$, density 10.0

$0.53389 \pm 0.00302$ $g / m i$ 
NMSL: $\quad 90240$

Engineer: MSO01.3

Date:

December 1991

Page: 85 of 116

\section{TABLE 11. CONTINUED}

12 Same as Case 1, except $17.5 \mathrm{ml}$, density $11.4 \quad 0.53951 \pm 0.00327$ $\mathrm{g} / \mathrm{m} \mathbf{1}$

13 Same as Case 1, except $15 \mathrm{ml}$, density $13.3 \quad 0.53542 \pm 0.00308$ $g / m 1$

14 Same as Case 1, except $14.2 \mathrm{ml}$, density $14.10 .53952 \pm 0.00321$ $\mathrm{g} / \mathrm{m} \mathbf{1}$

15 Same as Case 1, except $12.5 \mathrm{ml}$, density $16.0 \quad 0.54476 \pm 0.00321$ $\mathrm{g} / \mathrm{ml}$

16 Same as Case 1 , except $11.1 \mathrm{ml}$, density $18.0 \quad 0.54859 \pm 0.00301$ $g / m 1$

17 Same as Case 1 , except $10.08 \mathrm{ml}$, density $19.84 \quad 0.55603 \pm 0.00317$ $\mathrm{g} / \mathrm{ml}$ 
NMSL: $\quad 90240$

Engineer: MSOD 3

Date: Dece 1991

Page: 86 of 116

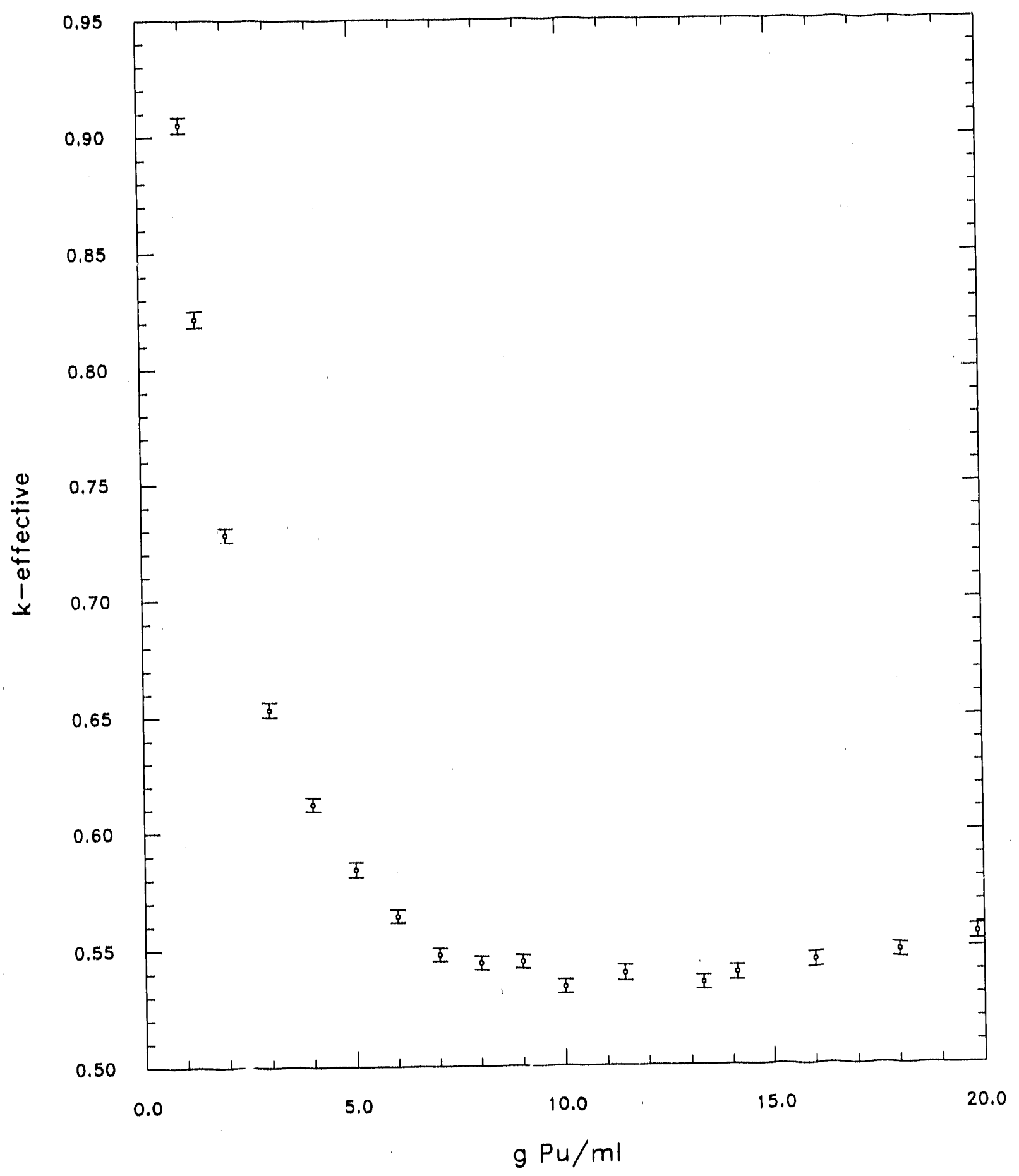

Figure 5. Density vs k-effective; 200 grams Pu per can, cans stacked 3 high.

1049- HES-0691-04 
NMSL: $\quad 90240$

Engineer: MSOOL.3

Date: December 1991

Page: 87 of 116

\section{DRAFT LIMIT}

Limits estabiished from this evaluation are based on the requirements for critfcality safety. If stricter 1 imits apply due to Safeguards and Security or other reasons, compliance with the most restrictive 1 imits is required.

The following limits apply to RFP one-gallon containers regardless of inner containment. Separation limits from other fisstle material are not required. Beryllium shall not be placed in one-gallon cans.

\section{Storage Limits}

Solids and slurries (mass $1 \mathrm{imit}$ ):

1. The mass of fissile material (uranium or plutonium metal or oxide) shall not exceed $50 \mathrm{~g}$ per one-galion container. Metal slurries (any liquid containing undissolved $U$ or $\mathrm{Pu}$ solids) are also subject to this 50 g mass limit. The mass limit applies to the bulk weight of material. 2. Containers shall be limited to planar arrays (i.e., stacking of containers is not allowed).

Plutonium solutions (volume limit):

1. The volume of plutonium solution (urganic or aqueous with no visible solids) shall not exceed $100 \mathrm{ml}$ per one-gallon container.

2. Containers shall be limited to planar arrays (i.e., stacking of containers is not allowed).

\section{Iransport Limits}

Additionally, no more than 40 containers shall be allowed to be transported at one time. Because cans in transport are at risk of being damaged, limiting to 40 the number of containers allowed in one vehicle eliminates concerns over more than that number of cans being breached in a single location so that their collective contents coùiud accuimulate î́ à crittical geometry. 
NMSL: $\quad \frac{90240}{15001}$

Engtneer: MSOOL.3

Date: December 1921

Page: 88 of 116

\section{CALCULATIONS}

\subsection{Calculated Number Densities for Matertals}

\begin{tabular}{|c|c|c|c|}
\hline Descriotion & $\begin{array}{l}\text { Nuclide or } \\
\text { Material }\end{array}$ & $\begin{array}{l}\text { KENO-V. } a^{5} \\
\text { Library ID }\end{array}$ & $\begin{array}{l}\text { Atom/barn-cm } \\
\text { (Volume Fraction) }\end{array}$ \\
\hline $\begin{array}{l}\text { U-233 metal with density of } \\
18.70 \mathrm{~g} / \mathrm{cm}^{3}\end{array}$ & $U-233$ & 92301 & $4.83300-2$ \\
\hline $\begin{array}{l}\text { U-233 slurry } \\
(5000 \mathrm{~g} / 1 \mathrm{U})\end{array}$ & $\begin{array}{l}\text { U-233 } \\
\text { Water } \\
\text { Polyethylene }\end{array}$ & $\begin{array}{l}92303 \\
92304 \\
502 \\
402\end{array}$ & $\begin{array}{l}1.29227-3 \\
1.16304-3 \\
(0.6740) \\
(0.0586)\end{array}$ \\
\hline $\begin{array}{l}\text { Pu metal wjth density of } \\
19.84 \mathrm{~g} / \mathrm{cm}^{3}\end{array}$ & $\begin{array}{l}\text { Pu-239 } \\
P u-240\end{array}$ & $\begin{array}{l}94901 \\
94003 \\
94004\end{array}$ & $\begin{array}{l}4.74882-2 \\
1.64930-3 \\
8.39647-4\end{array}$ \\
\hline $\begin{array}{l}\text { Pu slurry } \\
(5000 \mathrm{~g} / 1 \mathrm{PL} ;\end{array}$ & $\begin{array}{l}\text { Pu-239 } \\
\text { Pu-240 } \\
\text { Water } \\
\text { Polyethylene }\end{array}$ & $\begin{array}{l}94904 \\
94905 \\
94007 \\
94008 \\
502 \\
402\end{array}$ & $\begin{array}{l}1.09505-2 \\
1.01726-3 \\
6.05333-4 \\
2.19226-5 \\
(0.6881) \\
(0.0598)\end{array}$ \\
\hline $\begin{array}{l}\text { Pu solution } 1000 \mathrm{~g} / \mathrm{L} \text { in } \\
\text { in } 92 \text { vol. } \% \text { water, } 8 \text { vol. } \\
\text { polyethylene }\end{array}$ & $\begin{array}{l}\text { Pu-239 } \\
\text { Pu-240 } \\
\text { Water } \\
\text { Polyethylene }\end{array}$ & $\begin{array}{r}94907 \\
94908 \\
94010 \\
94011 \\
502 \\
402\end{array}$ & $\begin{array}{l}2.12069-3 \\
2.72866-4 \\
9.63766-5 \\
2.90746-5 \\
(0.92) \\
(0.08)\end{array}$ \\
\hline Carbon Steel & $\begin{array}{l}\mathrm{C} \\
\mathrm{Fe}\end{array}$ & $\begin{array}{r}6100 \\
26100\end{array}$ & $\begin{array}{l}3.92100-3 \\
8.34910-2\end{array}$ \\
\hline Lead & $\mathrm{Pb}$ & 82100 & $3.29600-2$ \\
\hline Ordinary Concrete & & 301 & $(1.00)$ \\
\hline
\end{tabular}


NMSL: $\quad 90240$

Engineer: MSOOL. 3

Date: December 1991

Page: 89 of 116

\subsection{Calculation of Average $k_{0}+4$}

As required at RFP, calculations upon which 1 imits are based were repeated three times with different random number sequences (accomplished by using three different start types [NST=0,1,2]). The ihree $k_{\text {off }}$ values: $k_{1}, k_{2}$, and $k_{3}$, were combined statistically as follows:

$$
\begin{aligned}
k & =\frac{\sum_{i=1}^{3}\left(k_{i} / \sigma_{i}^{2}\right)}{\sum_{i=1}^{3}\left(1 / \sigma_{i}^{2}\right)} \text { and } \\
\sigma & =\left[\sum_{i=1}^{3}\left(1 / q^{2}\right)\right]^{-\frac{1}{2}}
\end{aligned}
$$

These calculated $k_{\text {eff }}$ values were also verified to meet the RFP acceptance criteria in that each individual $k_{\text {eff }}$ value, when rounded to three decimal places, is within the range $k \pm 0.010$ where $k=\left(k_{1}+k_{2}+k_{3}\right) / 3$; and that each individual sigma is less than or equal to 0.005 . 
NMSL: $\quad 90240$

Engtneer: MSO01,3

Date:

December 1991

Page: 90 of 116

15. KENO-V.A INPUT LISTINGS

Listing 1. KENO-V.a Input Listing for Case 1 of Table 2.

Listing 2. KENO-V.a Input Listing for Case 13 of Table 2.

Lifting 3. KENO-V.a Input Listing for Case 19 of Table 2.

Listing 4. KENO-V.a Input Listing for Case 1 of Table 4.

Listing 5. KENO-V.a Input Listing for Case 8 of Table 4.

Listing 6. KENO-V.a Input Listing for Case 4 of Table 7.

Listing 7. KENO-V.a Input Listing for Case 5 of Table 7.

Listing 8. KENO-V.a Input Listing for Case 1 of Table 8.

Listing 9. KENO-V.a Input Listing for Case 4 of Table 8.

Listing 10. KENO-V.a Input Listing for Case 9 of Table 8.

Listing 11. KENO-V.a Input Listing for Case 14 of Table 9.

Listing 12. KENO-V.a Input Listing for Case 18 of Table 9.

Listing 13. KENO-V.a Input Listing for Case 2 of Table 11. 
NMSL: $\quad \frac{90240}{4 S 001}$

Engineer: $\mathrm{MSOOL}, 3$

Date: December 1991

Page: 91 of 116

Listing 1. KENO-V.a Input Listing for Case 1 of Table 2

GAL110 100 G PU METAL; INFINITE ARRAY; SPHERICAL FUEL

READ PARA

TME $=120.0 \quad$ GEN $=153 \quad$ NPG $=407 \quad L I B=41$

$F L X=N O \quad F D N=N O \quad A M X=N O \quad F A R=N O$

RUN=YES PLT=YES

END PARA

READ MIXT

$\begin{array}{llllll}\text { MIX }=1 & 94901 & 4.74882-2 & & \\ & 94003 & 1.64930-3 & 94004 & 8.39647-4 \\ \text { MIX-2 } & 6100 & 3.92100-3 & 26100 & 8.34910-2\end{array}$

MIX=3 $301 \quad 1.0$

END MIXT

READ GEOM

UNIT 1

ZHEMICYL+X

HOLE

$\begin{array}{llll}0 & 1 & 8.308975 & 2 P 9.737725\end{array}$

$\begin{array}{lll}0.0 & 7.245345 & -8.67409\end{array}$

$\begin{array}{lllll}2 H E M I C Y L+X & 2 & 1 & 8.334375 & 2 \mathrm{Pg} .763125\end{array}$

UNIT 2

ZHEMICYL - $X$

$\begin{array}{llll}0 & 1 & 8.308975 & 2 P 9.737725\end{array}$

HOLE

$\begin{array}{lll}0 & 0.07 .245345 & -8.67409\end{array}$

ZHEMICYL-X $\quad 21 \quad 8.334375 \quad 2 P 9.763125$

UNIT 3

ZHEMICYL+Y

$\begin{array}{llll}0 & 1 & 8.308975 & 2 P 9.737725\end{array}$

HOLE

$\begin{array}{lllll}6 & 7.245345 & 0.0 & -8.67409\end{array}$

ZHEMICYL+Y

$21.8 .334375 \quad 2 P 9.763125$

UNIT 4

HEMISPHE+X 111.06363

UNIT 5

HEMISPHE $-X \quad 111.06363$

UNIT 6

HEMISPHE+Y 111.06363

UNIT 7

HEMISPHE-Y 1111.06363

UNIT 8

ZHEMICYL+X $\quad 0118.308975 \quad 2 P 9.737725$

HOLE $4 \quad 0.07 .245345+8.67409$

ZHEMICYL+X $21 \quad 8.334375 \quad 2$ P9.763125

UNIT 9

ZHEMICYL-X $\quad 01 \quad 8.308975 \quad 2 P 9.737725$

HOLE $\quad 5 \quad 0.07 .245345+8.67409$

ZHEMICYL-X $\quad 21 \quad 8.334375 \quad 2 P 9.763125$

UNIT 10

ZHEMICYL+Y $\quad 0118.308975 \quad 2 P 9.737725$

HOLE $\quad 6 \quad 7.2453450 .0+8.67409$

ZHEMICYL+Y $\quad 21 \quad 8.334375 \quad 2 P 9.763125$

UNIT 11

CON=* UNIT CELL, FUEL OFFSET TO BOTTON OF CAN *

ZHEMICYL-Y $\quad 018.308975 \quad 2$ P9.737725

HOLE

$7.245345 \quad 0.0 \quad-8.67409$ 
NMSL: $\quad 90240$

Engineer: MSOO1.3

Date: December 1991

Page: 92 of 116

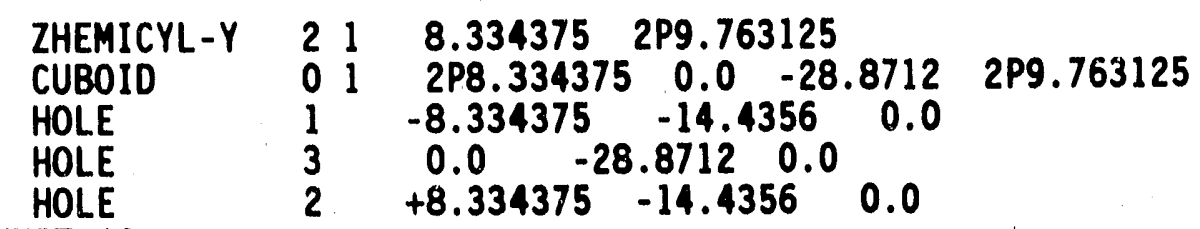

UNIT 12

COM=* UNIT CELL, FUEL OFFSET TO TOP OF CAN *

ZHEMICYL-Y O $\quad 8$ 8.308975 2 P9.737725

$\begin{array}{lll}\text { HOLE } & 7 & 7.2453450 .0+8.67409\end{array}$

ZHEMICYL-Y $21 \quad 8.334375 \quad 2 P 9.763125$

$\begin{array}{lllllll}\text { CUBOID } & 0 & 1 & 2 \text { P8.334375 } & 0.0 & -28.8712 & 2 P 9.763125\end{array}$

$\begin{array}{lllll}\text { HOLE } & 8 & -8.334375 & -14.4356 & 0.0\end{array}$

$\begin{array}{lllll}\text { HOLE } & 10 & 0.0 & -28.8712 & 0.0\end{array}$

$\begin{array}{lllll}\text { HOLE } & 9 & +8.334375 & -14.4356 & 0.0\end{array}$

UNIT 13

COM=* ARRAY OF CANS STACKED TWO HIGH *

$\begin{array}{llllll}\text { ARRAY } & 1 & -8.34 & -29.0 & -19.528\end{array}$

GLOBAL

UNIT 14

COM=* ARRAY OF CANS STACKED TWENTY HIGH *

$\begin{array}{lllll}\text { ARRAY } & 2 & -8.34 & -29.0 & -195.28\end{array}$

REPLICATE $3 \quad 2 \quad 4 * 0.0 \quad 2 * 5.0 \quad 6$

END GEOM

REPLICATE $3 \quad 8 \quad 5 * 0.0 \quad 5.0 \quad 6$

READ START NST $=0$ END START

READ ARRAY ARA $=1 \quad N U X=1 \quad N U Y=1 \quad N U Z=2$

FILL 1211 END FILL

$A R A=2 \quad N U X=1 \quad N U Y=1 \quad N U Z=10$

FILL F13 END FILL

END ARRAY

READ BIAS ID=301 213 FND BIAS

READ BOUNDS XYF=MIRROR END BOUNDS

READ PLOT

PLT $=Y$ YES PIC $=$ MIX NCH=' $* 0 *$.

TTL $=$ * "X-Y SLICE THROUGH ORIGIN" *

$X U L=-8.34 \quad$ YUL $=0.0 \quad Z U L=-18.6$

$X L R=8.34 \quad Y L R=-29.0 \quad Z L R=-18.6$

$U A X=1.0 \quad V D N=-1.0 \quad N A X=130 \quad$ END

END PLOT

END DATA 
NMSL: $\quad 90240$

Engineer: $\mathrm{MSO01}, 3$

Date: December 1991

Page: 93 of 116

Listing 2. KENO-V.a Input Listing for Case 13 of Table 2

GAL121 100 G PU METAL; INFINITE ARRAY; SPHERICAL FUEL, FLOODED

READ PARA

TME $=80.0$ GEN=153 NPG=407 LIB=\{.

$F L X=N O \quad F D N=N O \quad A M X-N O \quad F A R=N O$

END PARA

RUN-YES PLT=YES

READ MIXT

MIX=1 $94901 \quad 4.74882-2$

$\begin{array}{lllll} & 94003 & 1.64930-3 & 94004 & 8.39647-4 \\ \text { MIX=2 } & 6100 & 3.92100-3 & 26100 & 8.34910-2 \\ \text { MIX=3 } & 301 & 1.0 & & \\ \text { MIX=4 } & 502 & 0.1 & & \end{array}$

END MIXT

READ GEOM

UNIT 1

ZHEMICYL+X $\quad 011 \quad 8.308975 \quad 2 P 9.737725$

$\begin{array}{lllll}\text { HOLE } & 4 & 0.0 & 7.245345 & -8.67409\end{array}$

ZHEMICYL+X $\quad 211 \quad 8.334375 \quad 2 P 9.763125$

UNIT 2

ZHEMICYL-X $\quad 0 \quad 1 \quad 8.308975 \quad 2 P 9.737725$

$\begin{array}{lllll}\text { HOLE } & 5 & 0.07 .245345 & -8.67409\end{array}$

ZHEMICYL-X $\quad 211 \quad 3.334375 \quad 2 P 9.763125$

UNIT 3

ZHEMICYL+Y $\quad 0 \quad 1 \quad 8.308975 \quad 2 P 9.737725$

$\begin{array}{llllll}\text { HOLE } & 6 & 7.245345 & 0.0 & -8.67409\end{array}$

ZHEMICYL+Y $211 \quad 8.334375 \quad 2 P 9.763125$

UNIT 4

HEMISPHE+X 1111.05363

UNIT 5

HEMISPHE-X 1111.06363

UNIT 6

HEMISPHE+Y 1111.06363

UNIT 7

HEMISPHE-Y 1111.06363

UNIT 8

ZHEMICYL+X $\quad 0 \quad 1 \quad 8.308975 \quad 2 P 9.737725$

HOLE ... $4 \quad 0.07 .245345+8.67409$

ZHEMICYL+X $\quad 21 \quad 8.334375 \quad 2 P 9.763125$

UNIT 9

ZHEMICYL-X $\quad 001 \quad 8.308975 \quad 2 P 9.737725$

HOLE $\quad 5 \quad 0.07 .245345+8.67409$

ZHEMICYL-X $\quad 21 \quad 8.334375 \quad 2 P 9.763125$

UNIT 10

ZHEMICYL+Y $\quad 0 \quad 1 \quad 8.308975 \quad 2 P 9.737725$

$\begin{array}{llll}\text { HOLE } & 6 & 7.245345 & 0.0+8.67409\end{array}$

ZHEMICYL+Y $\quad 211 \quad 8.334375 \quad 2 P 9.763125$

UNIT 11

COM=* UNIT CELL, FUEL OFFSET TO BOTTOM OF CAN *

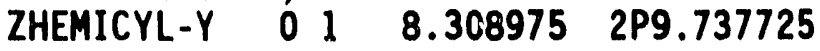


NMSL: $\quad 90240$

Engineer: MSOO1.3

Date: $\quad$ December 1991

Page: 9 - of 116

$\begin{array}{llllll}\text { HOLE } & 7 & 7.245345 & 0.0 & -8.67409 & \\ \text { ZHEMICYL-Y } & 2 & 1 & 8.334375 & 2 P 9.763125 & \\ \text { CUBOID } & 4 & 2 P 8.334375 & 0.0 & -28.8712 & 2 P 9.763125 \\ \text { HOLE } & 1 & -8.334375 & -14.4356 & 0.0 & \\ \text { HOLE } & 3 & 0.0 & -28.8712 & 0.0 & \end{array}$

UNIT 12

COM=* UNIT CELL, FUEL OFFSET TO TOP OF CAN *

ZHEMICYL-Y $01 \quad 8.3089752$ 2P9.737725

$\begin{array}{lll}\text { HOLE } & 7 & 7.2453450 .0+8.67409\end{array}$

ZHEMICYL-Y $\quad 21 \quad 8.334375 \quad 2$ P9.753125

CUBOID

HOLE

HOLE

$\begin{array}{lllll}4 & 1 & 2 P 8.334375 & 0.0 & -28.8712\end{array}$

$\begin{array}{llll}8 & -8.334375 & -14.4356 & 0.0\end{array}$

HOLE

$\begin{array}{llll}10 & 0.0 & -28.8712 & 0.0\end{array}$

$9+8.334375 \quad-14.4356 \quad 0.0$

$2 P 9.763125$

UNIT 13

COM $=$ * ARRAY OF CANS STACKED TWO HIGH *

GLOBAL

$\begin{array}{lllll}\text { ARRAY } & 1 & -8.34 & -29.0 & -19.528\end{array}$

UNIT 14

COM=* ARRAY OF CANS STACKED TWENTY HIGH *

$\begin{array}{llllll}\text { ARRAY } & 2 & -8.34 & -29.0 & -195.28\end{array}$

REPLICATE $3 \quad 2 \quad 4 * 0.0 \quad 2 * 5.06$

END GEOM

REPLICATE $3 \quad 3 \quad 5 * 0.0 \quad 5.0 \quad 6$

READ START NST $=0$ END START

READ ARRAY ARA $=1 \quad N U X=1 \quad N U Y=1 \quad N U Z=2$

FILL 1211 END FILL

$A R A=2 \quad N U X=1 \quad N U Y=1 \quad N U Z=10$

FILL F13 END FILL

END ARRAY

READ BIAS ID $=301213$ END BIAS

READ BOUNDS XYF=MIRROR END BOUNDS

READ PLOT

PLT $=Y E S \quad P I C=M I X \quad N C H=\prime$ *O\#.'

TTL $=\star$ "X-Y SLICE THROUGH FUEL" *

$X U L=-8.34 \quad Y U L=0.0 \quad Z U L=-18.468$

$X L R=8.34 \quad Y L R=-29.0 \quad Z L R=-18.468$

$U A X=1.0 \quad V D N=-1.0 \quad N A X=130 \quad$ END

END PLOT

END DATA 
NMSL: $\quad \frac{90240}{\text { Engineer: }}$

Date: December 1991

Page: 95 of .116

Listing 3. KENO-V.a Input Listing for Case 19 of Table 2

SLURP $5000 \mathrm{G} / \mathrm{L}$ PU; INFINITE ARRAY STACKED $20 \mathrm{HI} ; .02$ LITER VOL

READ PARA

TME $=170.0 \quad$ GEN $=153 \quad$ NPG $=507 \quad L I B=41$

$F L X=N O \quad F D N=N O \quad A M X=N O \quad F A R=N O$

END PARA

RUN-YES PLT=YES

READ MIXT

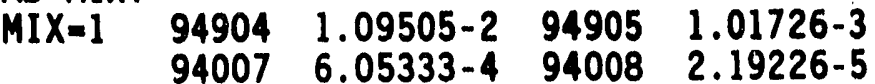

$\begin{array}{llll}502 & .6881 & 402 & .0598\end{array}$

MIX=2 $6100 \quad 3.92100-3 \quad 26100 \quad 8.34910-2$

MIX=3 $301 \quad 1.0$

END MIXT

READ GEOM

UNIT 1

HEMISPHE $+X \quad 111.68389$ ORIGIN 0.0

ZHEMICYL+X $\quad 0118.308975 \quad 2 P 9.737725$

$6.625085-8.053835$

ZHEMICYL+X $\quad 21 \quad 8.334375 \quad 2 P 9.763125$

UNIT 2

HEMISPHE- $X \quad 111 \quad 1.68389$ ORIGIN 0.0

ZHEMICYL- $X \quad 0 \quad 1 \quad 8.308975 \quad 2 P 9.737725$

ZHEMICYL-X $21 \quad 8.334375 \quad 2 P 9.763125$

$6.625085-8.053835$

UNIT 3

$\begin{array}{llllllll}\text { HEMISPHE } Y & 1 & 1 & 1.68389 & \text { ORIGIN } & 6.625085 & 0.0 & -8.053835\end{array}$

ZHEMICYL+Y $\quad 0 \quad 1 \quad 8.308975 \quad 2 P 9.737725$

ZHEMICYL+Y $\quad 21 \quad 8.334375 \quad 2 P 9.763125$

UNIT 4

HEMISPHE-Y $\quad 1 \quad 1 \quad 1.68389$ ORIGIN $6.6250850 .0 \quad-8.053835$

ZHEMICYL-Y $\quad 0118.308975$ 2P9.737725

ZHEMICYL-Y $\quad 21 \quad 8.334375 \quad 2 P 9.763125$

CUBOID $\quad 01$

$\begin{array}{llll}2 \mathrm{~PB} .334375 & 0.0 & -28.8712 & 2 \mathrm{Pg} .763125\end{array}$

HOLE

HOLE

HOLE

UNIT 5

HEMISPHE +X $\quad 11 \quad 1.68389$ ORIGIN $0.0 \quad 6.625085 \quad 8.053835$

ZHEMICYL+X $\quad 0 \quad 1 \quad 8.308975 \quad 2 P 9.737725$

ZHEMICYL+X $21 \quad 8.334375 \quad 2 P 9.763125$

UNIT 6

HEMISPHE $-X \quad 11$

ZHEMICYL-X 001

1.68389 ORIGIN 0.0

6.6250858 .053835

ZHEMICYL $-X$

$8.308975 \quad 2 P 9.737725$

ITE 7

HEMISPHE $+Y \quad 11$

$8.3343752 P 9.763125$

ZHEMICYL+Y 01

$\begin{array}{lllll}1.68389 & \text { ORIGIN } & 6.625085 & 0.0 & 8.053835\end{array}$

ZHEMICYL+Y

$8.308975 \quad 2 P 9.737725$

$8.3343752 P 9.763125$

UNIT 8

HEMISPHE-Y $111 \quad 1.68389$ ORIGIN $6.625085 \quad 0.0 \quad 8.053835$

ZHEMICYL-Y $\quad 0 \quad 1 \quad 8.308975 \quad 2 P 9.737725$ 
NMSL: $\quad 90240$

Engineer: MSOOI.3

Date: $\quad$ December 1991

Page: 96 of 116

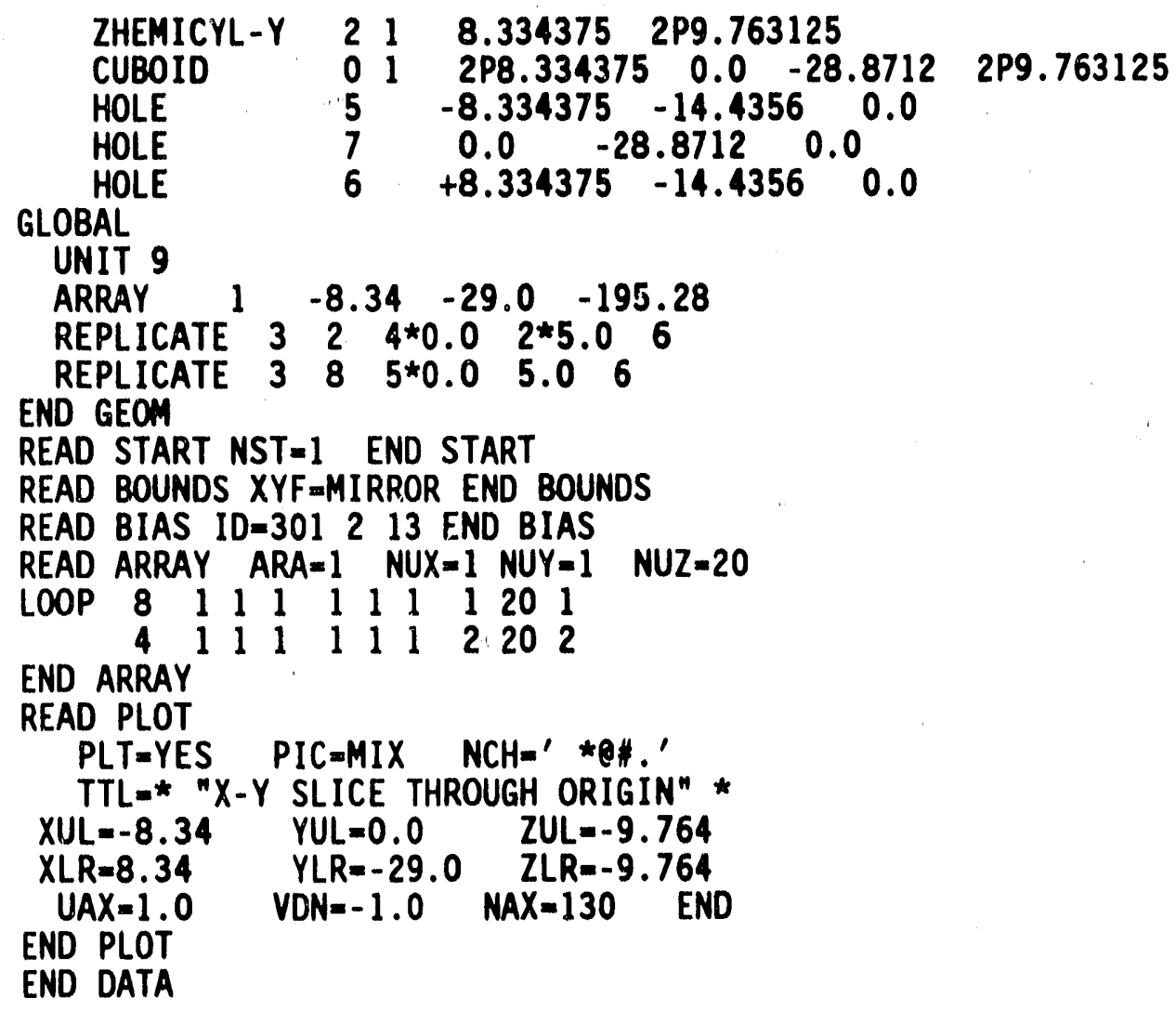


NMSL:
Engineer: $\frac{\frac{90240}{\text { MSOO1.3 }}}{\text { Date: }}$ December 1991

Page: 97 of 116

Listing 4. KENO-V.a Input Listing for Case 1 of Table 4

GAL504 $1000 \mathrm{G} / \mathrm{L}$ PU; INFINITE ARRAY STACKED $3 \mathrm{HI;} \mathrm{.20} \mathrm{LITER} \mathrm{VOL}$

READ PARA

TME $=70.0 \quad$ GEN=153 NPG $=407 \quad$ LIB $=41$

$F L X=N O \quad F D N=N O \quad A M X=N O \quad F A R=N O$

END PARA

RUN=YES PLT=YES

READ MIXT

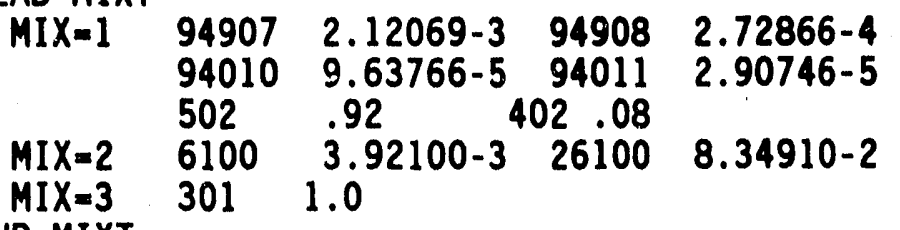

END MIXT

READ GEOM

UNIT 1

$\begin{array}{llllllll}\text { HEMISPHE+X } & 1 & 1 & 3.62783 & \text { ORIGIN } & 0.0 & 4.681145 & -6.109895 \\ \text { ZHEMICYL+X } & 0 & 1 & 8.308975 & 2 P 9.737725 & & \\ \text { ZHEMICYL+X } & 2 & 1 & 8.334375 & 2 P 9.763125 & & \\ \text { UNIT 2 } & & & & & & & \\ \text { HEMISPHE-X } & 1 & 1 & 3.62783 & \text { ORIGIN } & 0.0 & 4.681145 & -6.109895 \\ \text { ZHEMICYL-X } & 0 & 1 & 8.308975 & 2 P 9.737725 & & \\ \text { ZHEMICYL-X } & 2 & 1 & 8.334375 & 2 P 9.763125 & & \\ \text { ZHIT 3 } & & & & & & & \\ \text { HEMISPHE+Y } & 1 & 1 & 3.62783 & \text { ORIGIN } & 4.681145 & 0.0 & -6.109895 \\ \text { ZHEMICYL+Y } & 0 & 1 & 8.308975 & 2 P 9.737725 & & \\ \text { ZHEMICYL+Y } & 2 & 1 & 8.334375 & 2 P 9.763125 & & & \end{array}$

UNIT 4

COM=* UNIT CELL WITH FUEL OFFSET TO BOTTOM OF CANS *

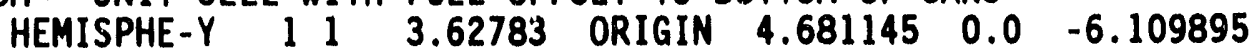

ZHEMICYL-Y $\quad 0 \quad 1 \quad 8.308975 \quad 2$ P9.737725

ZHEMICYL-Y $21 \quad 8.334375 \quad 2 P 9.763125$

$\begin{array}{lllllll}\text { CUBOID } & 0 & 1 & 2 P 8.334375 & 0.0 & -28.8712 & 2 P 9.763125\end{array}$

$\begin{array}{lllll}\text { HOLE } & 1 & -8.334375 & -14.4356 & 0.0\end{array}$

$\begin{array}{lllll}\text { HOLE } & 3 & 0.0 & -28.8712 & 0.0\end{array}$

$\begin{array}{lllll}\text { HOLE } & 2 & +8.334375 & -14.4356 & 0.0\end{array}$

UNIT 5

$\begin{array}{llllllll}\text { HEMISPHE }+X & 1 & 1 & 3.62783 & \text { ORIGIN } & 0.0 & 4.681145 & 6.109895\end{array}$

ZHEMICYL+X $\quad 0118.308975 \quad 2 P 9.737725$

ZHEMICYL+X $\quad 21 \quad 8.334375 \quad 2 P 9.763125$

UNIT 6

HEMISFHE $-X \quad 11 \quad 3.62783$ ORIGIN $\quad 0.0 \quad 4.681145 \quad 6.109895$

ZHEMIC II:-X $\quad 011 \quad 8.308975 \quad 2 P 9.737725$

ZHEMICYL-X $\quad 21 \quad 8.334375 \quad 2 P 9.763125$

UNIT 7

HEMISPHE+Y $\quad 1113.62783$ ORIGIN $4.681145 \quad 0.0 \quad 6.109895$

ZHEMICYL+Y $\quad 0118.308975 \quad 2 P 9.737725$

ZHEMICYL+Y $21 \quad 8.334375 \quad 2 P 9.763125$

UNIT 8

COM=* UNIT CELL WITH FUEL OFFSET TO TOP OF CANS * 
NMSL: $\quad 90240$

Engineer: $\mathrm{MSO01}, 3$

Date: December 1991

Page: 98 of 116

$\begin{array}{lllllll}\text { HEMISPHE-Y } & 1 & 1 & 3.62783 & \text { ORIGIN } 4.681145 & 0.0 & 6.109895 \\ \text { ZHEMICYL-Y } & 0 & 1 & 8.308975 & 2 P 9.737725 & & \\ \text { ZHEMICYL-Y } & 2 & 1 & 8.334375 & 2 P 9.763125 & & \\ \text { CUBOID } & 0 & 1 & 2 P 8.334375 & 0.0 & -28.8712 & 2 P 9.763125 \\ \text { HOLE } & 5 & -8.334375 & -14.4356 & 0.0 & \\ \text { HOLE } & 7 & 0.0 & -28.8712 & 0.0 & & \\ \text { HOLE } & 6 & +8.334375 & -14.4356 & 0.0 & \end{array}$

GLOBAL

COM=* ARRAY OF CANS STACKED THREE HIGH *

UNIT 9

$\begin{array}{lllll}\text { ARRAY } & 1 & -8.34 & -29.0 & -19.528\end{array}$

REPLICATE $3 \quad 2 \quad 4 * 0.0 \quad 2 * 5.0 \quad 6$

REPLICATE $3 \quad 8 \quad 5 * 0.0 \quad 5.06$

END GEOM

READ START NST $=0$ END START

READ BOUNDS XYF-MIRROR END BOUNDS

READ BIAS ID=301 2 13 END BIAS

READ ARRAY ARA=1 NUX=1 NUY=1 NUZ=3 FILL 844 END FILL

END ARRAY

READ PLOT

PLT $=Y$ YES PIC=MIX NCH=' $* 0 *{ }^{\prime}$

TTL $=$ * "X-Y SLICE THROUGH ORIGIN" *

$X U L=-8.34 \quad$ YUL $=0.0 \quad Z U L=-9.764$

$X L R=8.34 \quad Y L R=-29.0 \quad Z L R=-9.764$

$U A X=1.0 \quad V D N=-1.0 \quad N A X=130 \quad$ END

END PLOT

END DATA 
NMSL: $\quad 90240$

Engineer: MSOO1.3

Date: December 1991

Page: 99 of 116

Listing 5. KENO-V.a Input Listing for Case 8 of Table 4

GAL503 $1000 \mathrm{G} / \mathrm{L}$ PU;INFINITE PLANAR ARRAY; . 10 LITER VOL READ PARA

TME $=60.0 \quad$ GEN $=153 \quad$ NPG $=407 \quad$ LIB $=41$

$F L X=N O \quad F D N=N O \quad A M X=N O \quad F A R=N O$

END PARA

RUN=YES PLT=YES

READ MIXT

$\begin{array}{lllll}M I X=1 & 94907 & 2.12069-3 & 94908 & 2.72866-4 \\ & 94010 & 9.63766-5 & 94011 & 2.90746-5\end{array}$

MIX=2 $6100 \quad 3.92100-3 \quad 26100 \quad 8.34910-2$

MIX $=3 \quad 301 \quad 1.0$

END MIXT

READ GEOM

UNIT 1

HEMISPHE $+X \quad 1 \quad 1 \quad 2.879412$

ZHEMICYL $+X \quad 0118.308975 \quad 2 P 9.737725$

$\begin{array}{lllll}\text { ZHEMICYL+X } & 21 & 8.334375 & 2 P 9.763125\end{array}$

UNIT 2

HEMISPHE $-X \quad 112.879412$

ZHEMICYL-X $\quad 0118.308975 \quad 2$ P9.737725

ZHEMICYL-X $21 \quad 8.334375 \quad 2 P 9.763125$

UNIT 3

HEMISPHE $+Y \quad 112.879412$

ZHEMICYL+Y $0118.308975 \quad 2 P 9.737725$

GLOBAL

ZHEMICYL+Y $21 \quad 8.334375 \quad 2 P 9.763125$

UNIT 4

HEMISPHE-Y $\quad 112.879412$

ZHEMICYL-Y $0118.308975 \quad 2 P 9.737725$

ZHEMICYL-Y $21 \quad 8.334375 \quad 2 P 9.763125$

CUBOID

HOLF

HOLE

01

$2 \mathrm{P} 8.334375 \quad 0.0 \quad-28.8712 \quad 2 \mathrm{Pg} .763125$

HOLE

$1 \quad-8.334375-14.4356$

$0.034375 \quad 0.006$

$\begin{array}{lll}0.0 & -28.8712 & 0.0\end{array}$

REPLICATE $3 \quad 2 \quad 4 * 0.0 \quad 2 * 5.0 \quad 6$

REPLICATE $3 \quad 8 \quad 5 * 0.0 \quad 5.0 \quad 6$

END GEON

READ START NST $=0$ END START

READ BOUNDS XYF=MIRROR END BOUNDS

READ BIAS ID=301 213 END BIAS

READ PLOT

PLT $=Y E S \quad P I C=M I X \quad N C H=\prime * Q * .^{\prime}$

TTL $=$ * "X-Y SLICE THROUGH ORIGIN" *

$X U L=-8.34 \quad Y U L=0.0 \quad Z U L=0.0$

$X L R=8.34 \quad Y L R=-29.0 \quad Z L R=0.0$

$U A X=1.0 \quad V D N=-1.0 \quad N A X=130 \quad$ END

END PLOT

END DATA 
NMSL: $\quad 90240$

Engineer: MSOO1.3

Date: December 1991

Page: 100 of 116

Listing 6. KENO-V.a Input Listing for Case 4 of Table 7

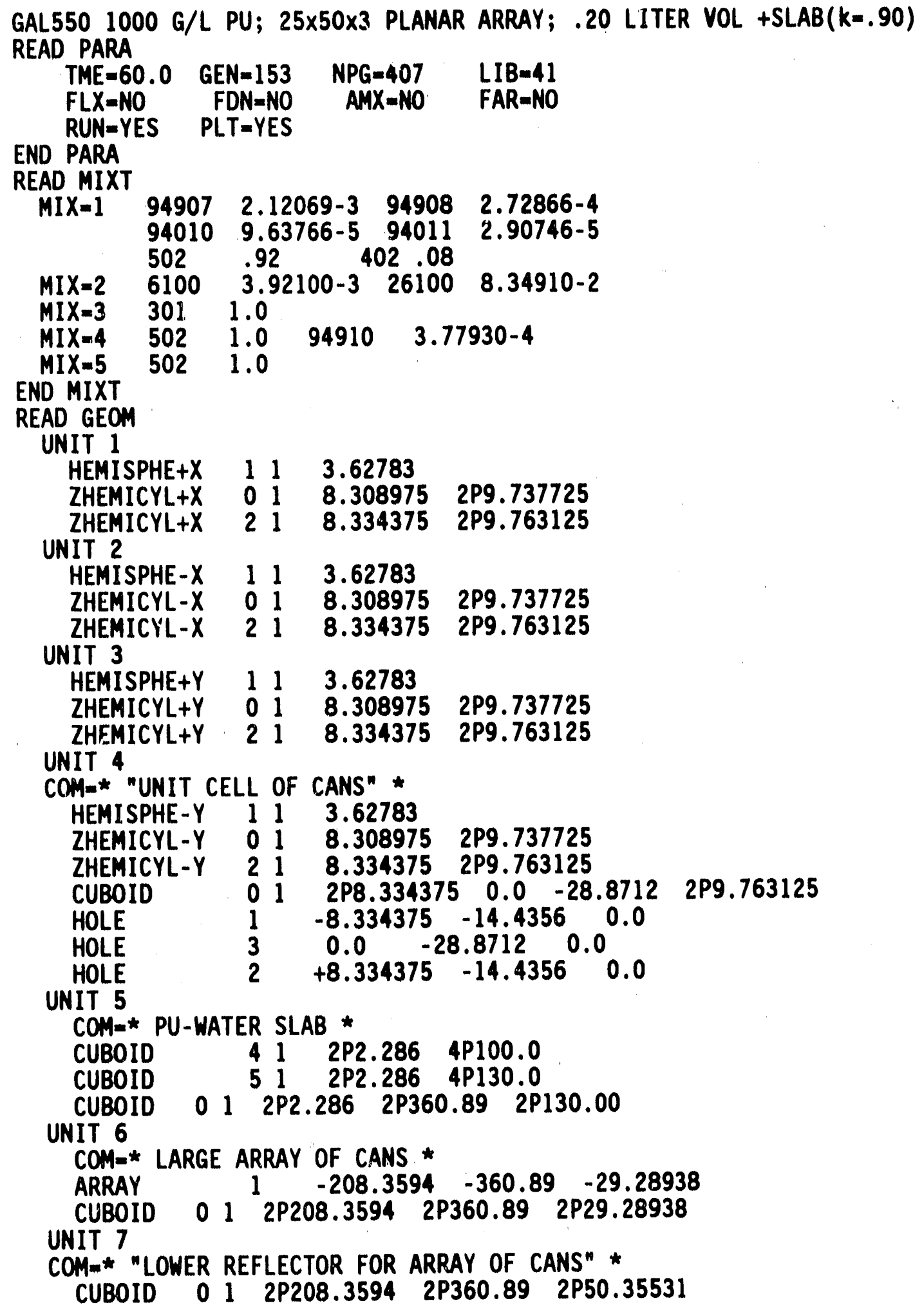


NMSL: $\quad \frac{90240}{4 S 001}$

Engineer: MSO01.3

Date: December 1991

Page: 101 of 116

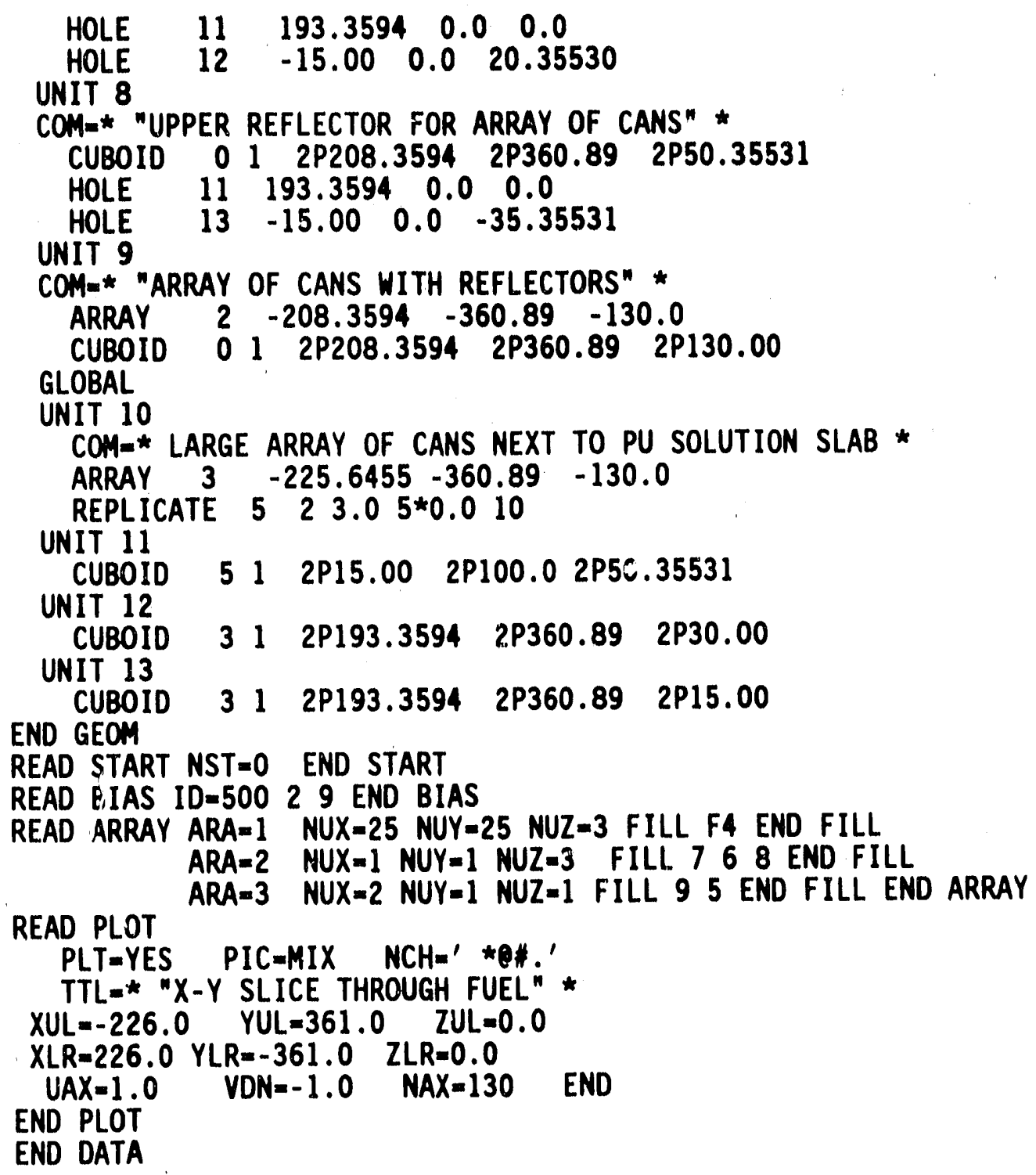


NMSL: $\quad 90240$

Engineer: MSO01.3

Date:

December 1991

Page: 102 of 116

Listing 7. KENO-V.a Input Listing for Case 5 of Table 7

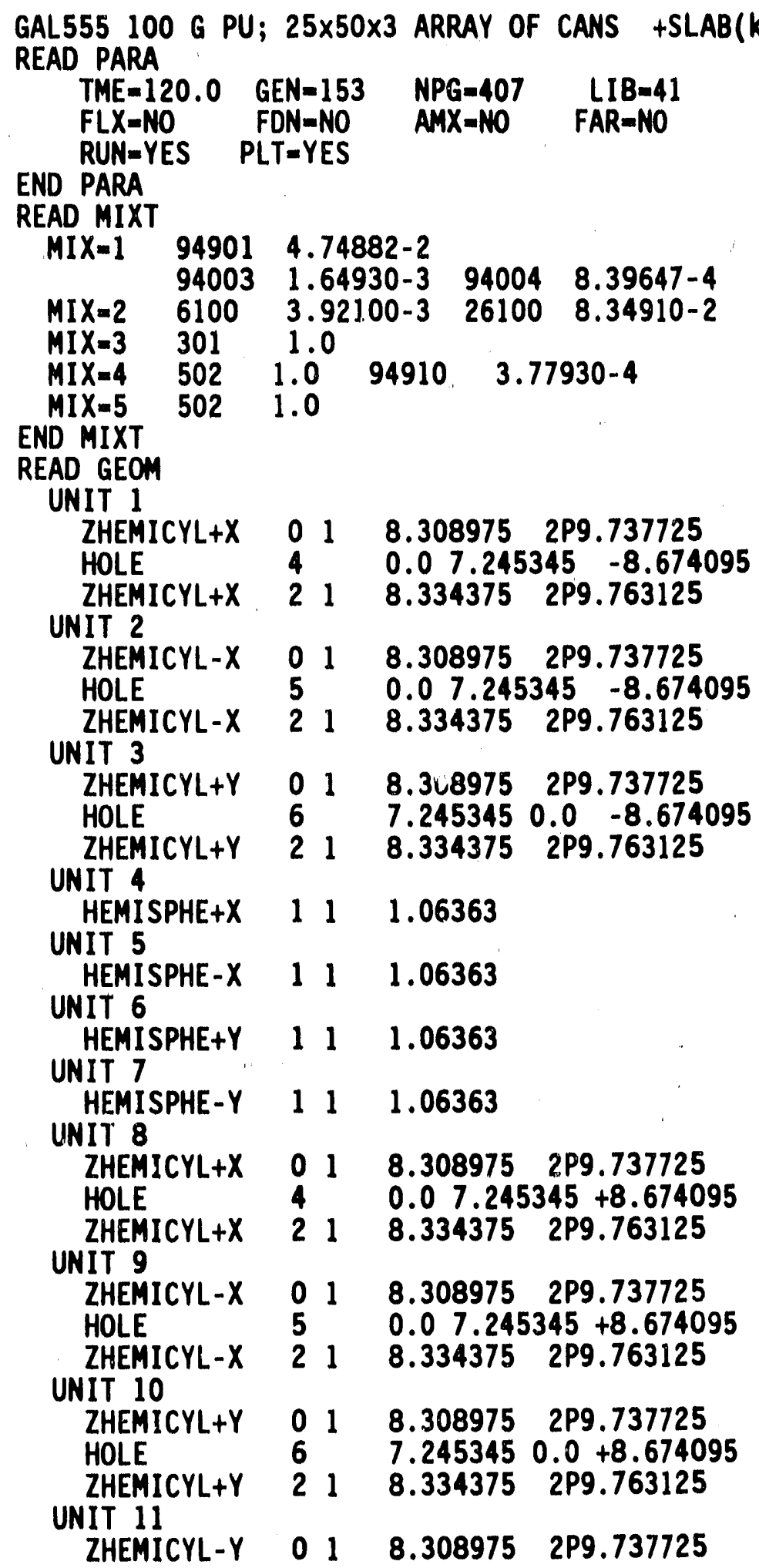


NMSL: $\quad 90240$

Engineer: MSOOL.3

Date: December 1991

Page: 103 of 116

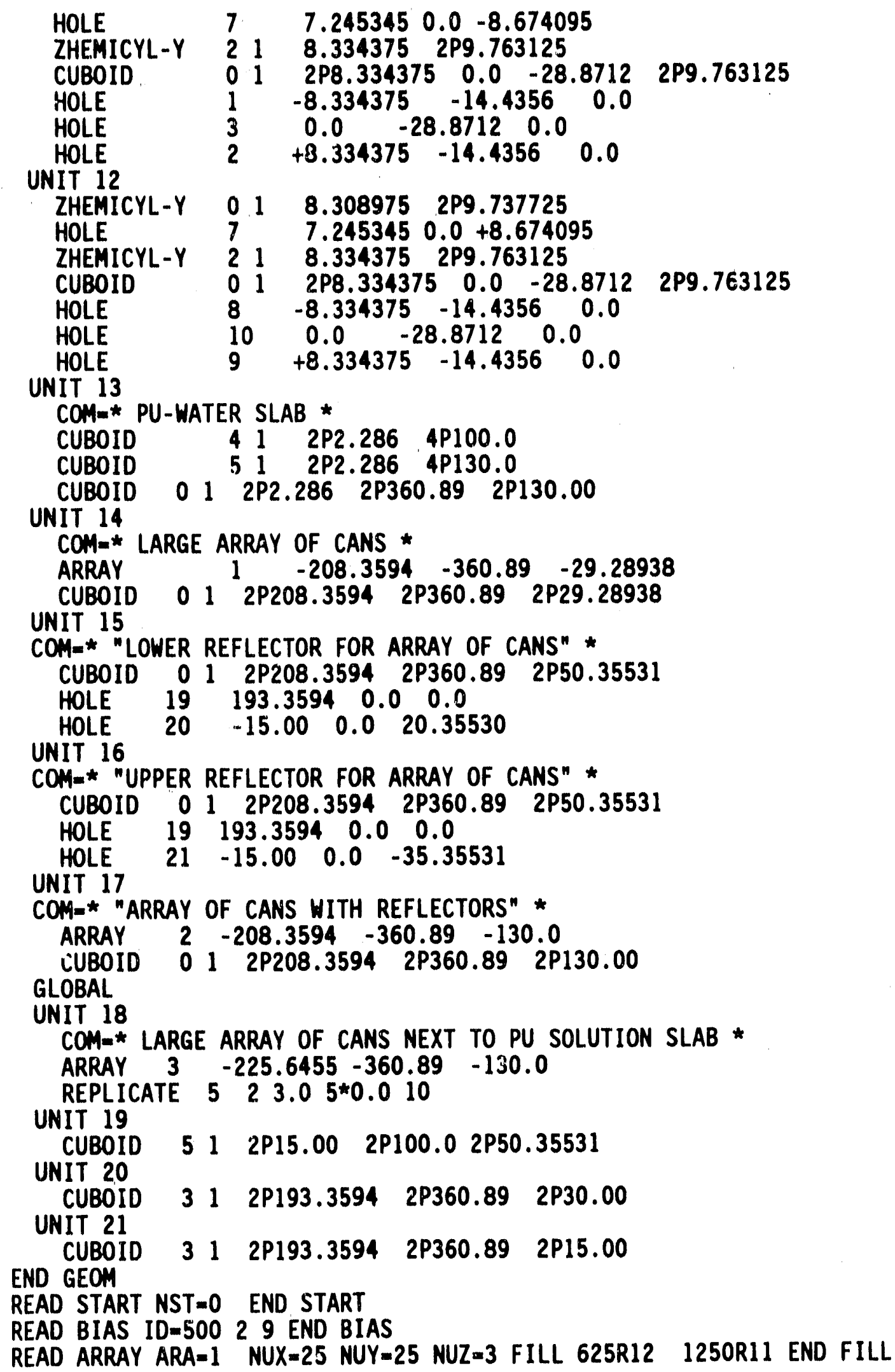


NMSL: $\quad 90240$

Engineer: MSOO1.3

Date: December 1991

Page: 104 of 116

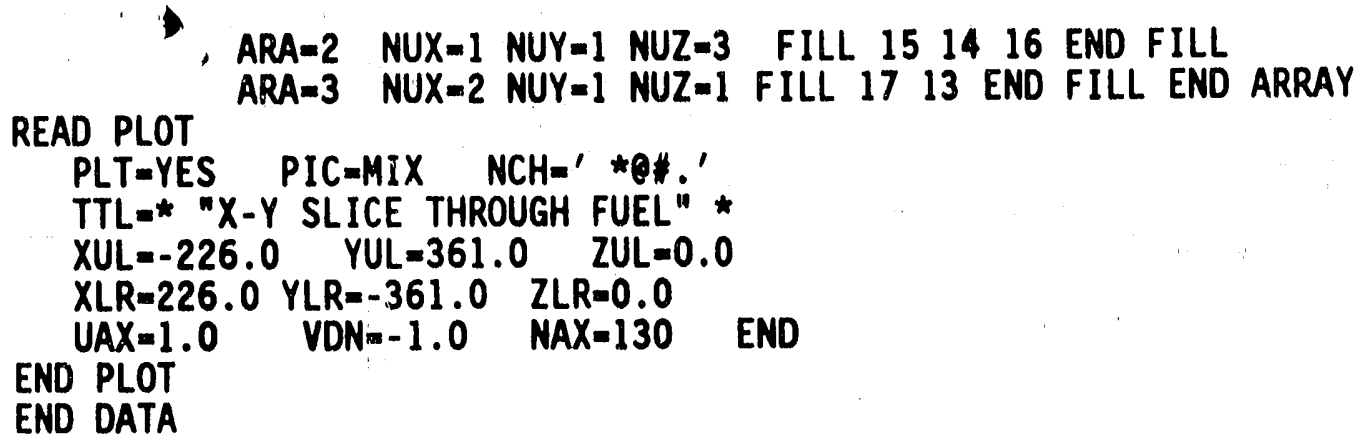


NMSL: $\quad 90240$

Engineer: MSO01.3

Date: December 1991

Page: 105 of 116

Listing 8. KENO-V.a Input Listing for Case 1 of Table 8

PILE OF 60100 G SPHERES OF PU METAL

READ PARA

TME $=120.0$ GEN-153 NPG=407 LIB=41

$F L X=N O \quad F D N=N O \quad A M X=N O \quad F A R-N O$

END PARA

RUN-YES PLT-YES

READ MIXT

$\begin{array}{lllll}\text { MIX-1 } & 94901 & 4.74882-2 & & \\ \text { MIX=2 } & 94003 & 1.64930-3 & 94004 & 8.39647-4 \\ 1.0 & & & \end{array}$

END MIXT

READ GEOM

UNIT 1

SPHERE $\quad 1111.06362$

GLOBAL

UNIT 2

CUBOID

HOLE

HOLE

HOLE

HOLE

HOLE

HOLE

HOLE

HOLE

HOLE

HOLE

HOLE

HOLE

HOLE

HOLE

HOLE

HOLE

HOLE

HOLE

HOLE

HOLE

HOLE

HOLE

HOLE

HOLE

HOLE

HOLE

HOLE

HOLE

HOLE

HOLE

HOLE

HOLE

$\begin{array}{ccccc}21 & 2 P 4.748152 & 2 P 5.31815 & 6.590414 & -2.910251 \\ 1 & 0.0 & 1.06363 & 0.0 & \\ 1 & 0.0 & -1.06363 & 0.0 & \\ 1 & 0.0 & 3.1989 & 0.0 & \\ 1 & 0.0 & -3.19089 & 0.0 & \\ 1 & 1.842261 & 0.0 & 0.0 & \\ 1 & -1.842261 & 0.0 & 0.0 \\ 1 & 1.842261 & -2.12726 & 0.0 \\ 1 & -1.842261 & -2.12726 & 0.0 & \\ 1 & 1.842261 & 2.12726 & 0.0 \\ 1 & -1.842261 & 2.12726 & 0.0 & \\ 1 & 0.0 & 0.0 & 1.842261 & \\ 1 & 0.0 & 2.12726 & 1.842261 & \\ 1 & 0.0 & -2.12726 & 1.842261 & \\ 1 & 0.0 & 4.25452 & 1.842261 & \\ 1 & 0.0 & -4.25452 & 1.842261 & \\ 1 & 1.842261 & 1.06363 & 1.842261 \\ 1 & 1.842261 & -1.06363 & 1.842261 & \\ 1 & 1.842261 & 3.19089 & 1.842261 & \\ 1 & 1.842261 & -3.19089 & 1.842261 & \\ 1 & -1.842261 & -1.06363 & 1.842261 & \\ 1 & -1.842261 & 1.06363 & 1.842261 & \\ 1 & -1.842261 & 3.19089 & 1.842261 & \\ 1 & -1.842261 & -3.19089 & 1.842261 & \\ 1 & 3.684522 & 0.0 & 1.842261 & \\ 1 & -3.684522 & 0.0 & 1.842261 & \\ 1 & 3.684522 & 2.12726 & 1.842261 & \\ 1 & -3.684522 & 2.12726 & 1.842261 & \\ 1 & 3.684522 & -2.12726 & 1.842261 & \\ 1 & -3.684522 & -2.12726 & 1.842261 & \\ 1 & 0.0 & 0.0 & -1.846621 & \\ 1 & 0.0 & 2.12726 & -1.846621 & \\ 1 & 0.0 & -2.12726 & -1.846621 & \\ 1 & & & & \end{array}$


NMSL:
Engineer: $\frac{90240}{\text { MSO01.3 }}$
Date:

Page: 106 of 116

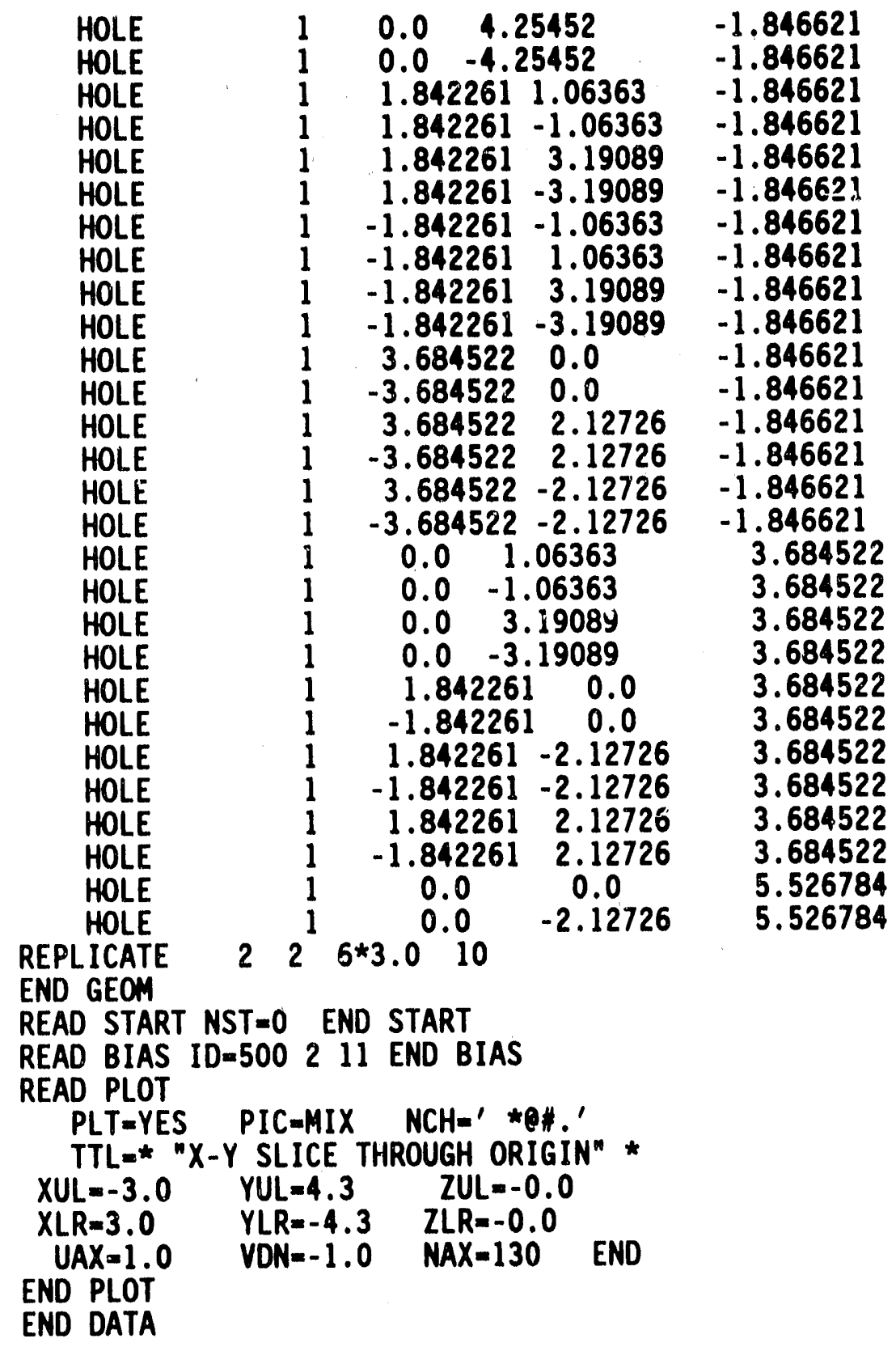


NMSL: $\quad 90240$

Engineer: $\mathrm{MSOO1}, 3$

Date: December 1991

Page: 107 of 116

Listing 9. KENO-V.a Input Listing for Case 4 of Table 8

CYL504 $1000 \mathrm{G} / \mathrm{L}$ PU; INFINITE ARRAY STACKED $3 \mathrm{HI} ; .20$ LITER VOL

READ PARA

TME $=70.0$ GEN=153 NPG=407 LIB $=41$

$F L X=N O \quad F D N=N O \quad A M X=N O \quad F A R=N O$

END PARA

RUN=YES PLT=YES

READ MIXT

MIX=1 $94907 \quad 2.12069-3 \quad 94908 \quad 2.72866-4$

$94010 \quad 9.63766-5 \quad 94011 \quad 2.90746-5$

MIX=2 $\quad 6100 \quad 3.92100-3 \quad 26100 \quad 8.34910-2$

MIX=3 $301 \quad 1.0$

END MIXT

READ GEOM

UNIT 1

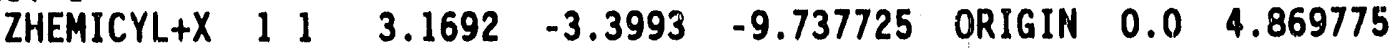

ZHEMICYL+X $\quad 0 \quad 1 \quad 8.308975 \quad 2 P 9.737725$

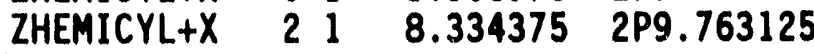

UNIT 2

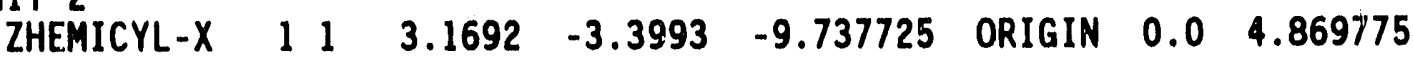

ZHEMICYL-X $\quad 0$ 1 $8.308975 \quad 2$ P9.737725

ZHEMICYL-X $\quad 21 \quad 8.334375 \quad 2 P 9.763125$

UNIT 3

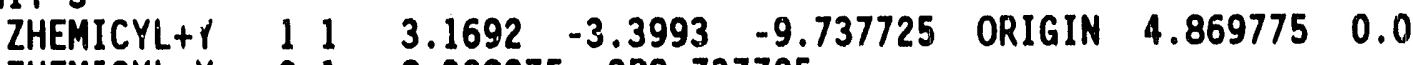

ZHEMICYL+Y $\quad 0 \quad 1 \quad 8.308975 \quad 2 P 9.737725$

ZHEMICYL+Y $\quad 21 \quad 8.334375 \quad 2 P 9.763125$

UNIT 4

COM=* UNIT CELL WITH FUEL OFFSET TO BOTTOM OF CANS *

ZHEMICYL-Y $1113.1692 \quad-3.3993 \quad-9.737725$ ORIGIN 4.8697750 .0

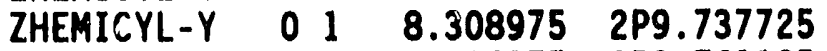

ZHEMICYL-Y $\quad 21 \%$

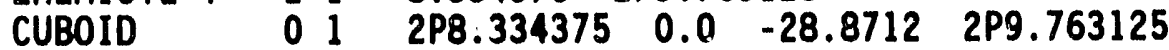

HOLE

HOLE

$\begin{array}{lll}-8.334375 & -14.4356 & 0.0\end{array}$

HOLE

UNIT 5

$\begin{array}{lllllllll}\text { ZHEMICYL+X } & 1 & 1 & 3.1692 & 9.737725 & 3.3993 & \text { ORIGIN } & 0.0 & 4.869775\end{array}$

ZHEMICYL+X $\quad 0$ 1 $\quad 8.308975 \quad 2 P 9.737725$

ZHEMICYL+X $\quad 218.8334375 \quad 2 P 9.763125$

UNIT 6

ZHEMICYL-X $\quad 1 \quad 1 \quad 3.1692 \quad 9.7377253 .3993 \quad$ ORIGIN $\quad 0.0 \quad 4.869775$

ZHEMICYL-X $\quad 0 \quad 1 \quad 8.308975 \quad 2 P 9.737725$

ZHEMICYL-X $\quad 21 \quad 8.334375 \quad 2 P 9.763125$

UNIT 7

ZHEMICYL+Y $\quad 111 \quad 3.1692 \quad 9.7377253 .3993 \quad$ ORIGIN $4.869775 \quad 0.0$

ZHEMICYL+Y $\quad 0 \quad 1 \quad 8.308975 \quad 2 P 9.737725$

ZHEMICYL+Y $\quad 218 \quad 8.334375 \quad 2 P 9.763125$

UNIT 8

COM=* UNIT CELL WITH FUEL OFFSET TO TOP OF CANS * 
NMSL: $\quad 90240$

Engineer: MSOO1.3

Date:

December 1991

Page: 108 of 116

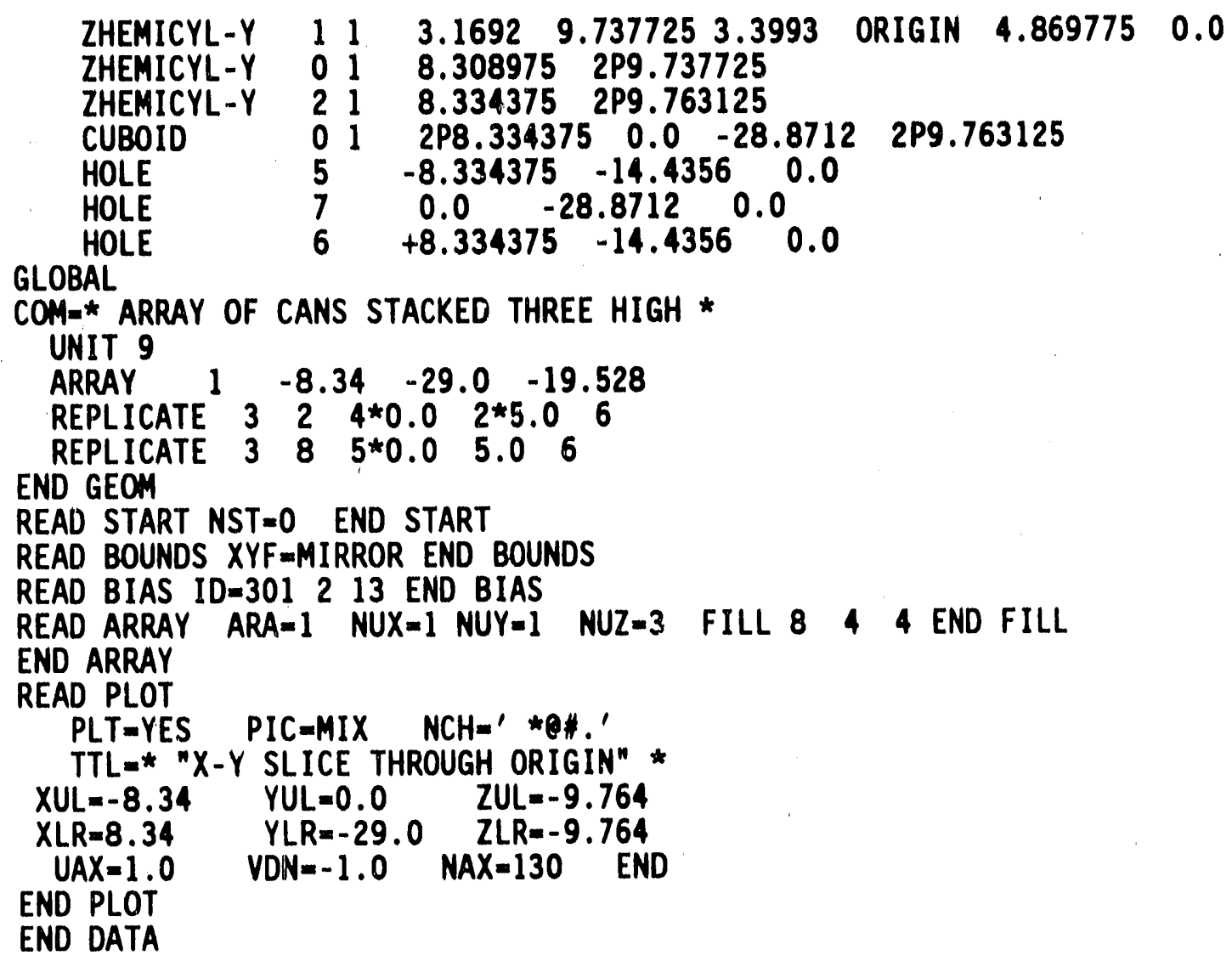

COM=* ARRAY OF CANS STACKED THREE HIGH *

UNIT 9

$\begin{array}{lllll}\text { ARRAY } & 1 & -8.34 & -29.0 & -19.528\end{array}$

REPLICATE $3 \quad 2 \quad 4 * 0.0 \quad 2 * 5.0 \quad 6$

REPLICATE $3 \quad 8 \quad 5 * 0.0 \quad 5.0 \quad 6$

END GEOM

READ START NST $=0$ END START

READ BOUNDS XYF=MIRROR END BOUNDS

READ BIAS ID $=301213$ END BIAS

READ ARRAY ARA=1 NUX=1 NUY=1 NUZ=3 FILL 8 \& END FILL

END ARRAY

READ PLOT

PLT $=Y E S \quad P I C=M I X \quad N C H=\prime * Q \#$.

TTL $=$ * " $X-Y$ SLICE THROUGH ORIGIN" *

$X U L=-8.34 \quad$ YUL $=0.0 \quad$ ZUL $=-9.764$

$X L R=8.34 \quad Y L R=-29.0 \quad Z L R=-9.764$

$U A X=1.0 \quad V D N=-1.0 \quad N A X=130 \quad$ END

END PLOT

END DATA 
NMSL:
Engineer: $\frac{\frac{90240}{M S 001.3}}{\text { Date: }} \quad \frac{\text { December } 1991}{\text { Date }}$

Page: 109 of 116

Listing 10. KENO-V.a Input Listing for Case 9 of Table 8

GAL161 100 G PU METAL; INFINITE ARRAY; SPHERICAL FUEL; RECTANGULAR PITCH READ PARA

TME $=120.0$ GEN=153 NPG-407 LIB=41

$F L X=N O \quad F D N=N O \quad A M X=N O \quad F A R=N O$

END PARA

RUN-YES PLT=YES

READ MIXT

$\begin{array}{lllll}M I X=1 & 94901 & 4.74882-2 & & \\ & 94003 & 1.64930-3 & 94004 & 8.39647-4\end{array}$

MIX=2 $6100 \quad 3.92100-3 \quad 26100 \quad 8.34910-2$

$M I X=3 \quad 301 \quad 1.0$

END MIXT

READ GEOM

UNIT 1

COM=* CAN WITH FUEL OFFSET TO RIGHT AND TOP OF CAN *

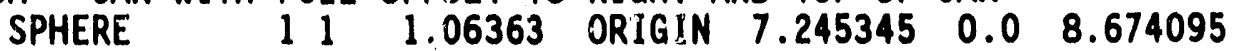

CYLINOER $\quad 0118.308975 \quad 2$ P9.737725

CYLINDER $\quad 21 \quad 8.334375 \quad 2 P 9.763125$

CUBOID $\quad 01$ 4P8.334375 2 P9.763125

UNIT 2

COM=* CAN WITH FUEL OFFSET TO LEFT AND IOP OF CAN *

$\begin{array}{llllll}S \text { SPHERE } & 1 & 1.06363 & \text { ORIGIN } & -7.245345 & 0.0\end{array}$

$\begin{array}{lllll}\text { CYLINDER } & 0 & 1 & 8.308975 & 2 P 9.737725\end{array}$

$\begin{array}{lllll}\text { CYLINDER } & 2 & 1 & \mathbf{8} .334375 & 2 P 9.763125\end{array}$

CUBOID $\quad 0 \mathrm{I} \quad 4$ P8.334375 2 P9.763125

UNIT 3

COM=* CAN WITH FUEL OFFSET TO RIGHT AND BOTTOM OF CAN *

$\begin{array}{lllllll} & \text { SPHERE } & 1 & 1.06363 & \text { ORIGIN } 7.245345 & 0.0 & -8.674095\end{array}$

CYLINDER $\quad 011 \quad 8.308975 \quad 2 P 9.737725$

$\begin{array}{lllll}\text { CYLINDER } & 21 & \mathbf{8} .334375 & 2 \mathrm{Pg} .763125\end{array}$

$\begin{array}{llll}\text { CUBOID } & 0 & 1 & 4 P 8.3343752 P 9.763125\end{array}$

UNIT 4

COM=* CAN WITH FUEL OFFSET TO LEFT AND BOTTOM OF CAN *

$\begin{array}{lllllll}S \text { SPHERE } & 1 & 1.06363 & \text { ORIGIN } & -7.245345 & 0.0 & -8.674095\end{array}$

CYLINDER $\quad 0 \quad 1 \quad 8.308975 \quad 2 P 9.737725$

$\begin{array}{lllll}\text { CYLINDER } & 2 & 1 & 8.334375 & 2 P 9.763125\end{array}$

CUBOID $\quad 01$ 4P8.334375 2P9.763125

UNIT 5

COM=* ARRAY OF CANS STACKED TWO HIGH *

$\begin{array}{llllll}\text { ARRAY } & 1 & -16.66875 & -8.334375 & -19.52625 \\ \text { CUBOID } & 0 & 1 & 2 \mathrm{P} 16.66875 & 2 \mathrm{P} 8.334375 & 2 \mathrm{P} 19.52625\end{array}$

GLOBAL

UNIT 6

COM=* ARRAY OF CANS STACKED TWENTY HIGH *

ARRAY $22-16.67-8.34-195.28$

REPLICATE $\quad 3 \quad 2 \quad 4 * 0.0 \quad 2 * 5.0 \quad 6$

END GEOM

$\begin{array}{lllllll}\text { REPLICATE } & 3 & 8 & 5 * 0.0 & 5.0 & 6\end{array}$

READ START NST $=0$ END START 
NMSL: $\quad 90240$

Engineer: $\mathrm{MSOO1.3}$

Date:

December 1991

Page: 110 of 116

\section{READ ARRAY}

$A R A=1 \quad N U X=2 \quad N U Y=1 \quad N U Z=2$

FILL 122344 END FILL

ARA-2 NUX=1 NUY=1 NUZ=10

FILL F5 END FILL

END ARRAY

READ BIAS ID=301 213 END BIAS

READ BOUNDS XYF-MIRROR END BOUNDS

READ PLOT

PLT-YES PIC-MIX NCH=' *O*.'

TTL $=\star$ " $X-Y$ SLICE THROUGH FUEL" *

$X U L=-16.67 \quad$ YUL $=8.34 \quad$ ZUL $=-9.764$

$X L R=16.67 \quad Y L R=-8.34 \quad Z L R=-9.764$

$U A X=1.0 \quad V D N=-1.0 \quad N A X=130 \quad$ END

END PLOT

END DATA 
NMSL: $\quad 90240$

Engineer: MSO01.3

Date: December 1991

Page: 111 of 116

Listing 11. KENO-V.a Input Listing for Case 14 of Table 9

USPR9 100 G U-233 METAL; INFINITE ARRAY; SPHERICAL FUEL

READ PARA

TME $=120.0 \quad G E N=153 \quad N P G=407 \quad L I B=41$

$F L X=N O \quad F D N=N O \quad A M X=N O \quad F A R=N O$

END PARA

RUN=YES PLT=YES

READ MIXT

$\begin{array}{lllll}\text { MIX-1 } & 92301 & 4.83300-2 & & \\ \text { MIX }=2 & 6100 & 3.92100-3 & 26100 & 8.34910-2 \\ \text { MIX=3 } & 301 & 1.0 & & \\ \text { MIX=4 } & 502 & 0.05 & & \end{array}$

END MIXT

READ GEOM

UNIT 1

ZHEMICYL+X

HOLE

ZHEMICYL+X

01

$8.308975 \quad 2 \mathrm{Pg} .737725$

$4 \quad 0.07 .224155 \quad-8.652905$

UNIT 2

ZHEMICYL-X

HOLE

21

$8.334375 \quad 2 P 9.763125$

ZHEMICYL-X

01

$8.3089752 P 9.737725$

$5 \quad 0.07 .224155 \quad-8.652905$

UNIT 3

ZHEMICYL+Y

HOLE

$\begin{array}{llll}21 & 8.334375 & 2 \mathrm{Pg} 9.763125\end{array}$

ZHEMICYL $+Y$

01

$8.308975 \quad 2 P 9.737725$

$\begin{array}{lllll}6 & 7.224155 & 0.0 & -8.652905\end{array}$

UNIT 4

$\begin{array}{llll}21 & 8.334375 & 2 P 9.763125\end{array}$

HEMISPHE $+X \quad 1111.084817$

UNIT 5

HEMISPHE - $X \quad 1111.084817$

UNIT 6

HEMISPHE+Y 1111.084817

UNIT 7

HEMISPHE-Y 1111.084817

UNIT 8

ZHEMICYL+X

HOLE

ZHEMICYL+X

UNIT 9

ZHEMICYL - X

HOLE

$\begin{array}{llll}0 & 1 & 8.308975 & 2 P 9.737725\end{array}$

$4 \quad 0.07 .224155+8.652905$

$\begin{array}{llll}21 & 8.334375 & 2 P 9.763125\end{array}$

ZHEMICYL-X

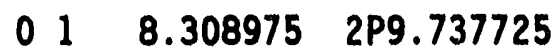

$5 \quad 0.07 .224155+8.652905$

UNIT 10

ZHEMICYL+Y

HOLE

ZHEMICYL+Y

$\begin{array}{llll}2 & 1 & 8.334375 & 2 P 9.763125\end{array}$

UNIT 11

ZHEMICYL-Y

HOLE

$\begin{array}{llll}0 & 1 & 8.308975 & 2 P 9.737725\end{array}$

$6 \quad 7.2241550 .0+8.652905$

$\begin{array}{llll}21 & 8.334375 & 2 P 9.763125\end{array}$

ZHEMICYL-Y

$\begin{array}{llll}0 & 1 & 8.308975 & 2 \mathrm{Pg} 9.737725\end{array}$

$7 \quad 7.224155 \quad 0.0 \quad-8.652905$

$21 \quad 8.334375 \quad 2 p 9.763125$ 
NMSL: $\quad 90240$

Eng ineer: $\mathrm{MSOO1.3}$

Date: December 1991

Page: 112 of 116

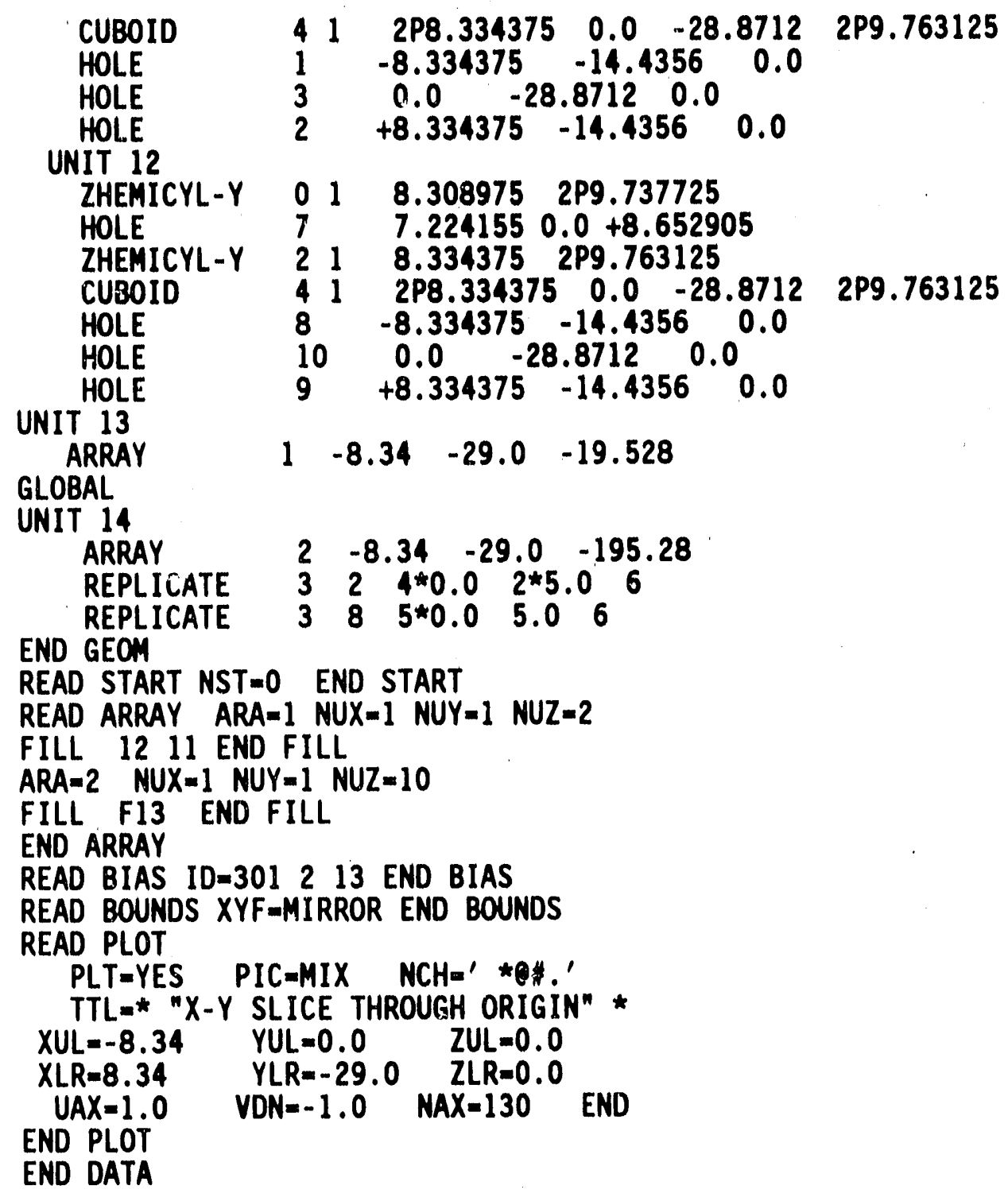


NMSL: $\quad 90240$

Engineer: MSOOL, 3

Date: December 1991

Page: 113 of 116

Listing 12. KENO-V.a Input Listing for Case 18 of Table 9

LEADSLR $5000 \mathrm{G} / \mathrm{L}$ U-233; INFINITE ARRAY STACKED $20 \mathrm{HI} ; .02$ LITER VOL, Pb READ PARA

TME $=170.0 \quad$ GEN $=153 \quad$ NPG $=407 \quad$ LIB $=41$

FLX-NO FDN=NO AMX=NO FAR-NO

END PARA

RUN-YES PLT=YES NUB=YES

READ MIXT

MIX=1 $92303 \quad 1.29227-3 \quad 92304 \quad 1.16304-3$

$\begin{array}{llll}502 & 0.674 & 402 & 0.0586\end{array}$

MIX=2 $\quad 6100 \quad 3.92100-3 \quad 26100 \quad 8.34910-2$

MIX $=3 \quad 301 \quad 1.0$

MIX=4 $82100 \quad 3.296-2$

ENID MIXT

READ GEOM

UNIT 1

HEMISPHE+X 1111.68389 ORIGIN 0.0

ZHEMICYL+X $\quad 011 \quad 7.038975 \quad 2$ P8.467725

ZHEMICYL+X $\quad 411 \quad 8.308975 \quad 2 P 9.737725$

ZHEMICYL+X $\quad 21 \quad 8.334375 \quad 2 P 9.763125$

UNIT 2

HEMISPHE-X 1111.68389 ORIGIN 0.0

ZHEMYCYL-X $\quad 0 \quad 1 \quad 7.038975 \quad 2$ P8.467725

$5.355085-6.783835$

ZHEMICYL-X $\quad 411 \quad 8.308975 \quad 2 P 9.737725$

ZHEMICYL-X $\quad 21 \quad 8.334375 \quad 2 P 9.763125$

$5.355085 \quad-6.783835$

UNIT 3

HEMISPHE+Y 11111.68389 ORIGIN $5.355085 \quad 0.0 \quad-6.783835$

ZHEMICYL+Y $001 \quad 7.038975 \quad 2 P 8.467725$

ZHEMICYL+Y $\quad 41 \quad 8.308975 \quad 2 P 9.737725$

ZHEMICYL+Y $\quad 211 \quad 8.334375 \quad 2 P 9.763125$

UNIT 4

HEMISPHE-Y $111 \quad 1.68389$ ORIGIN $5.3550850 .0 \quad-6.783835$

ZHEMICYL-Y $011 \quad 7.038975 \quad 2 P 8.467725$

ZHEMICYL-Y $\quad 411 \quad 8.308975 \quad 2 P 9.737725$

ZHEMICYL-Y $\quad 21 \quad 8.334375 \quad 2 P 9.763125$

CUBOID 01

HOLE

HOLE

HOLE

UNIT 5

$1 \quad-8.334375-14.4356 \quad 0.0$

$8712 \quad 2 \mathrm{PP} 9.763125$

$\begin{array}{lll}0.0 & -28.8712 \quad 0.0\end{array}$

$\begin{array}{lll}+8.334375 & -14.4356 & 0.0\end{array}$

HEMISPHE $+X \quad 1111.68389$ ORIGIN 0.0

ZHEMICYL+X $\quad 011 \quad 7.038975 \quad 2 P 8.467725$

ZHEMICYL+X $41 \quad 8.308975 \quad 2 P 9.737725$

ZHEMICYL+X $211 \quad 8.334375 \quad 2 P 9.763125$

UNIT 6

HEMISPHE- $X \quad 111.68389$ ORIGIN 0.0

ZHEMICYL-X $\quad 0 \quad 1 \quad 7.038975 \quad 2 P 8.467725$

ZHEMICYL-X $\quad 411 \quad 8.308975 \quad 2 P 9.737725$

ZHEMICYL-X $\quad 21 \quad 8.334375 \quad 2 P 9.763125$

$5.355085 \quad 6.783835$

UNIT 7 
NMSL: $\quad 90240$

Engineer: MSOO1.3

Date: December 1991

Page: 114 of 116

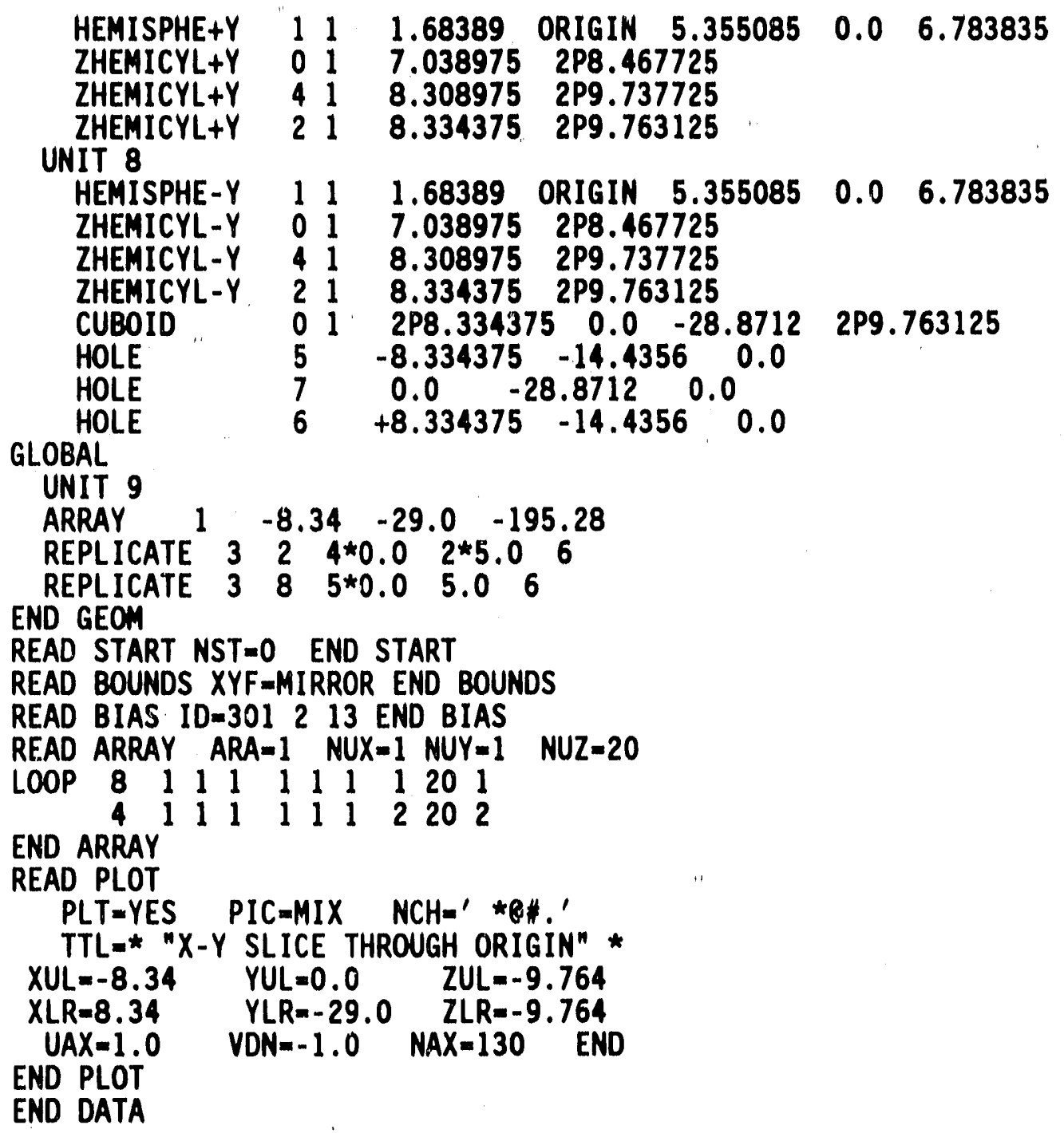


NMSL: $\quad 90240$

Engineer: MSOO1,3

Date:

December 1991

Page: 115 of 116

Listing 13. KENO-V.a Input Listing for Case 2 of Table 11

GALMIX1 PU METAL \& SOL; INFINITE ARRAY STACKED $3 \mathrm{HI}$

READ PARA

TME $=70.0 \quad$ GEN $=153 \quad$ NPG $=407 \quad$ LIB $=41$

$F L X=N O \quad F D N=N O \quad A M X=N O \quad F A R=N O$

END PARA

RUN=YES PLT=YES

READ MIXT

$\begin{array}{lllllll}\text { MIX }=1 & 94906 & 2.29941-3 & 94907 & \mathbf{8 . 9 1 9 9 9 - 4} & 94009 & \mathbf{5 . 4 4 4 9 9 - 5} \\ & 94010 & 1.12818-4\end{array}$

$\begin{array}{llll}94010 & 1.12818-4 & & \\ 502 & .8582 & 402 & .0746\end{array}$

MIX=2 $6100 \quad 3.92100-3 \quad 26100 \quad 8.34910-2$

MIX $=3 \quad 301 \quad 1.0$

END MIXT

READ GEOM

UNIT 1

$\begin{array}{llllllll}\text { HEMISPHE }+X & 1 & 1 & 3.29610 & \text { ORIGIN } & 0.0 & 5.012875 & -6.441625 \\ \text { ZHEMICYL+X } & 0 & 1 & 8.308975 & 2 P 9.737725 & & \end{array}$

ZHEMICYL+X $21 \quad 8.334375 \quad 2 P 9.763125$

UNIT 2

$\begin{array}{llllllll}\text { HEMISPHE } X & 1 & 1 & 3.29610 & \text { ORIGIN } & 0.0 & 5.012875 & -6.441625\end{array}$

ZHEMICYL-X $\quad 0 \quad 1 \quad 8.308975 \quad 2 P 9.737725$

ZHEMICYL-X $21 \quad 8.334375 \quad 2 P 9.763125$

UNIT 3

HEMISPHE+Y 1113.29610 ORIGIN $5.012875 \quad 0.0 \quad-6.441625$

ZHEMICYL+Y $011 \quad 8.308975 \quad 2 P 0.737725$

ZHEMICYL+Y $21 \quad 8.334375 \quad 2 P 9.763125$

UNIT 4

HEMISPHE-Y 113.29610 ORIGIN $5.012875 \quad 0.0 \quad-6.441625$

ZHEMICYL-Y 0108.308975 2P9.737725

ZHEMICYL-Y $21 \quad 8.334375 \quad 2 P 9.763125$

CUBOID $\quad 01$

HOLE 1

HOLE

HOLE

UNIT 5

$\begin{array}{llll}2 P 8.334375 & 0.0 & -28.8712 & 2 P 9.763125\end{array}$

$\begin{array}{lll}-8.334375 & -14.4356 & 0.0\end{array}$

$\begin{array}{lll}0.0 & -28.8712 & 0.0\end{array}$

$+8.334375-14.4356 \quad 0.0$

HEMISPHE $+X \quad 1 \quad 1 \quad 3.29610 \quad$ ORIGIN $\quad 0.0 \quad 5.012875 \quad 6.441625$

ZHEMICYL+X $\quad 01 \quad 8.308975 \quad 2 P 9.737725$

ZHEMICYL +X $\quad 21 \quad 8.334375 \quad 2 P 9.763125$

UNIT 6

HEMISPHE- $X \quad 11$

ZHEMICYL- $X$ O 01

3.29610 ORIGIN 0.0

5.0128756 .441625

ZHEMICYL-X 21

$8.308975 \quad 2 \mathrm{Pg} .737725$

$8.3343752 P 9.763125$

UNIT 7

HEMISPHE $+Y \quad 11 \quad 3.29610 \quad$ ORIGIN $\quad 5.012875 \quad 0.0 \quad 6.441625$

ZHEMICYL+Y $0118.308975 \quad 2 P 9.737725$

ZHEMICYL+Y $21 \quad 8.334375 \quad 2 P 9.763125$

UNIT 8

HEMISPHE-Y 1113.29610 ORIGIN $5.012875 \quad 0.0 \quad 6.441625$

ZHEMICYL-Y $018.308975 \quad 2$ P 9.737725 
NMSL: $\quad 90240$

Engineer: $\mathrm{MSOO1.3}$

Date:

December 1991

Page: 116 of 116

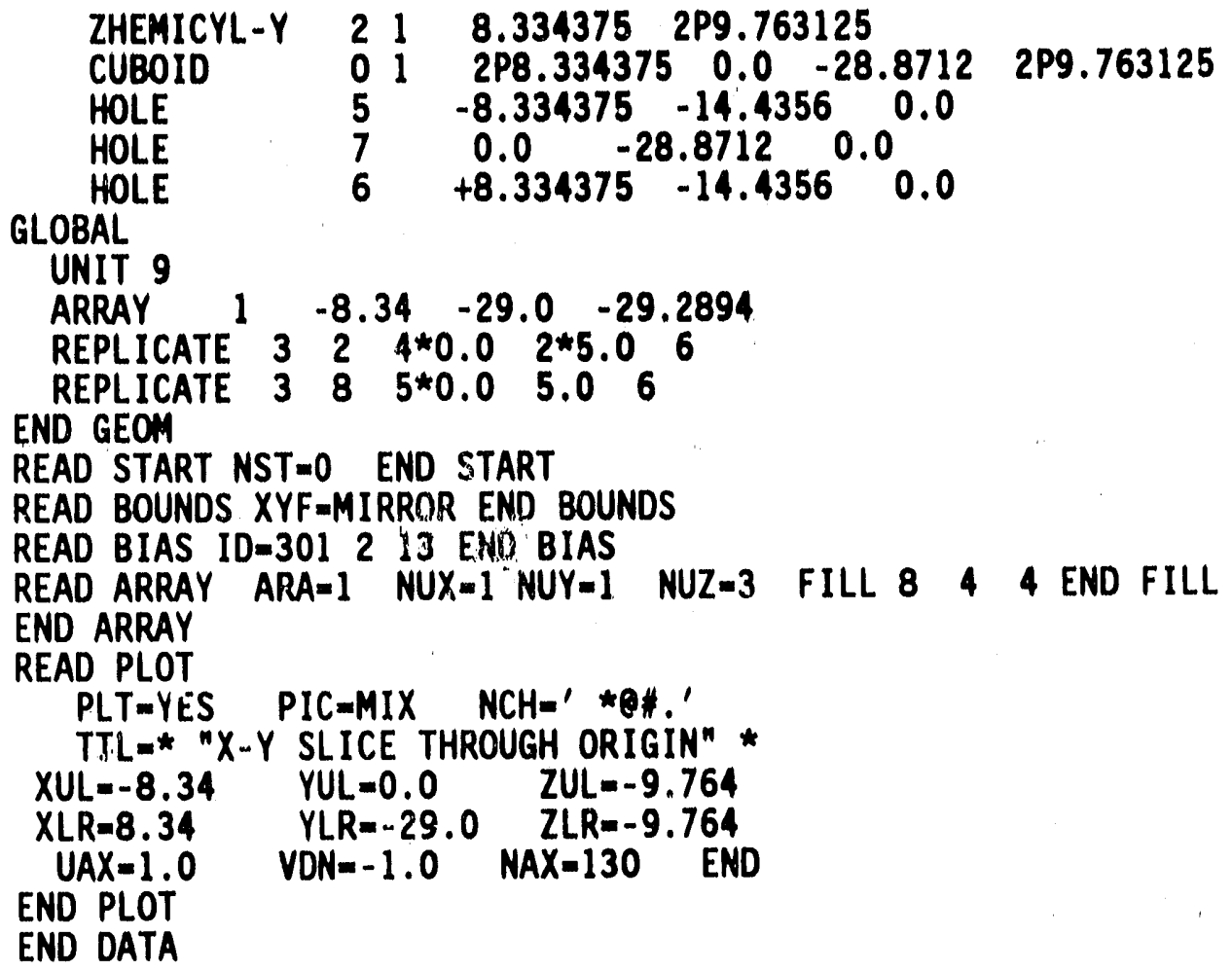

HOLE

HOLE

$\begin{array}{llll}5 & -8.334375 & -14.4356 & 0.0\end{array}$

HOLE $\quad 6 \quad+8.334375-14.4356 \quad 0.0$

GLOBAL

UNIT 9

ARRAY $1 \quad-8.34 \quad-29.0 \quad-29.2894$

REPLICATE $3 \quad 2 \quad 4 * 0.0 \quad 2 * 5.0 \quad 6$

REPLICATE $3 \quad 8 \quad 5 * 0.0 \quad 5.06$

END GEOM

READ START NST $=0$ END START

READ BOUNDS XYF=MIRROR END BOUNDS

READ BIAS ID=301 213 ENO BIAS

READ ARRAY ARA=1 NUX-1 NUY=1 NUZ=3 FILL 8 \& 4 END FILL

END ARRAY

READ PLOT

PLT=YES PIC=MIX NCH=' *O*.'

TIL $=$ * "X-Y SLICE THROUGH ORIGIN" *

XUL $=-8.34 \quad$ YUL $=0.0 \quad$ ZUL $=-9.764$

$X L R=8.34 \quad Y L R=-29.0 \quad Z L R=-9.764$

$U A X=1.0 \quad V D N=-1.0 \quad$ NAX $=130 \quad$ END

END PLOT

END DATA 

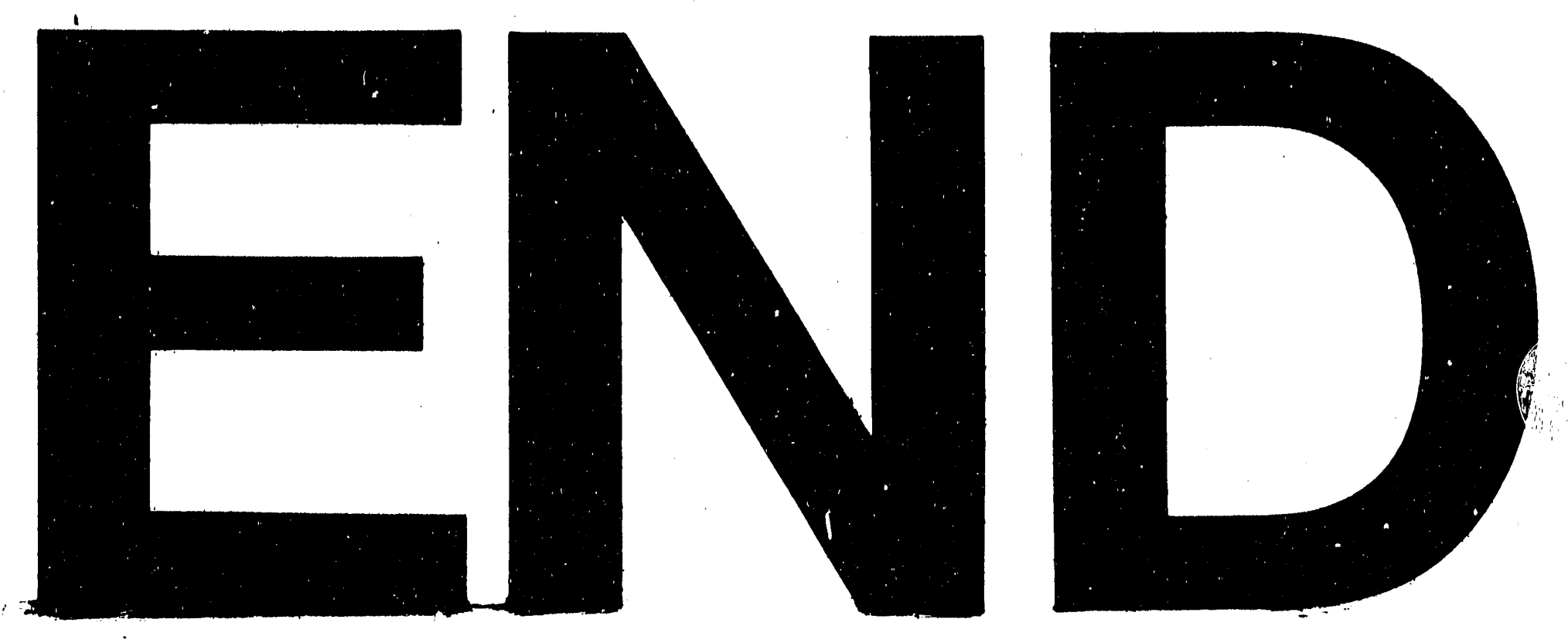

Fn in
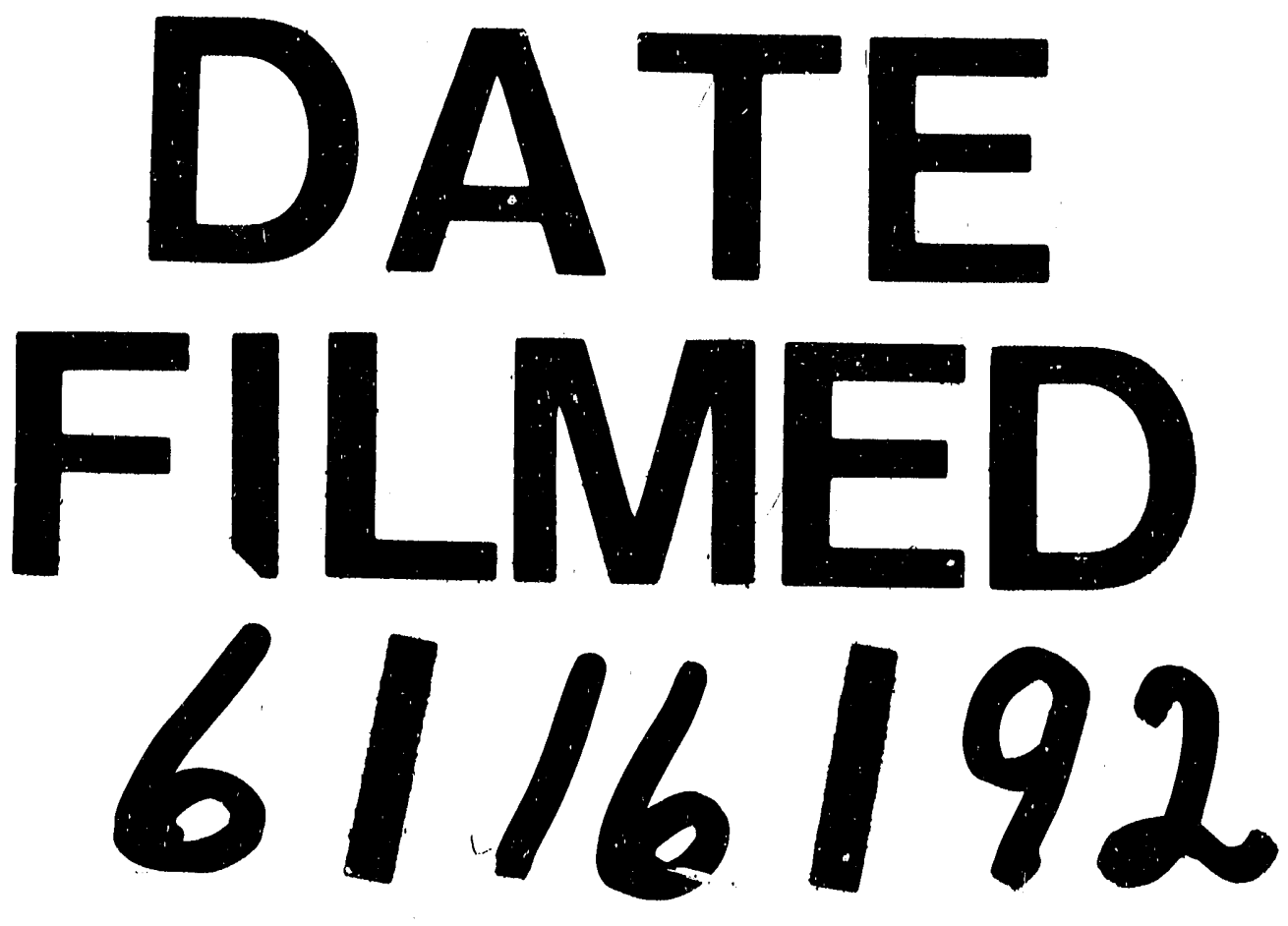